\title{
HYDROGEOLOGY AND GROUND-WATER-QUALITY CONDITIONS AT THE RENO COUNTY LANDFILL, SOUTH-CENTRAL KANSAS, 1990-91
}

\section{U.S. GEOLOGICAL SURVEY}

Water-Resources Investigations Report 92-4169

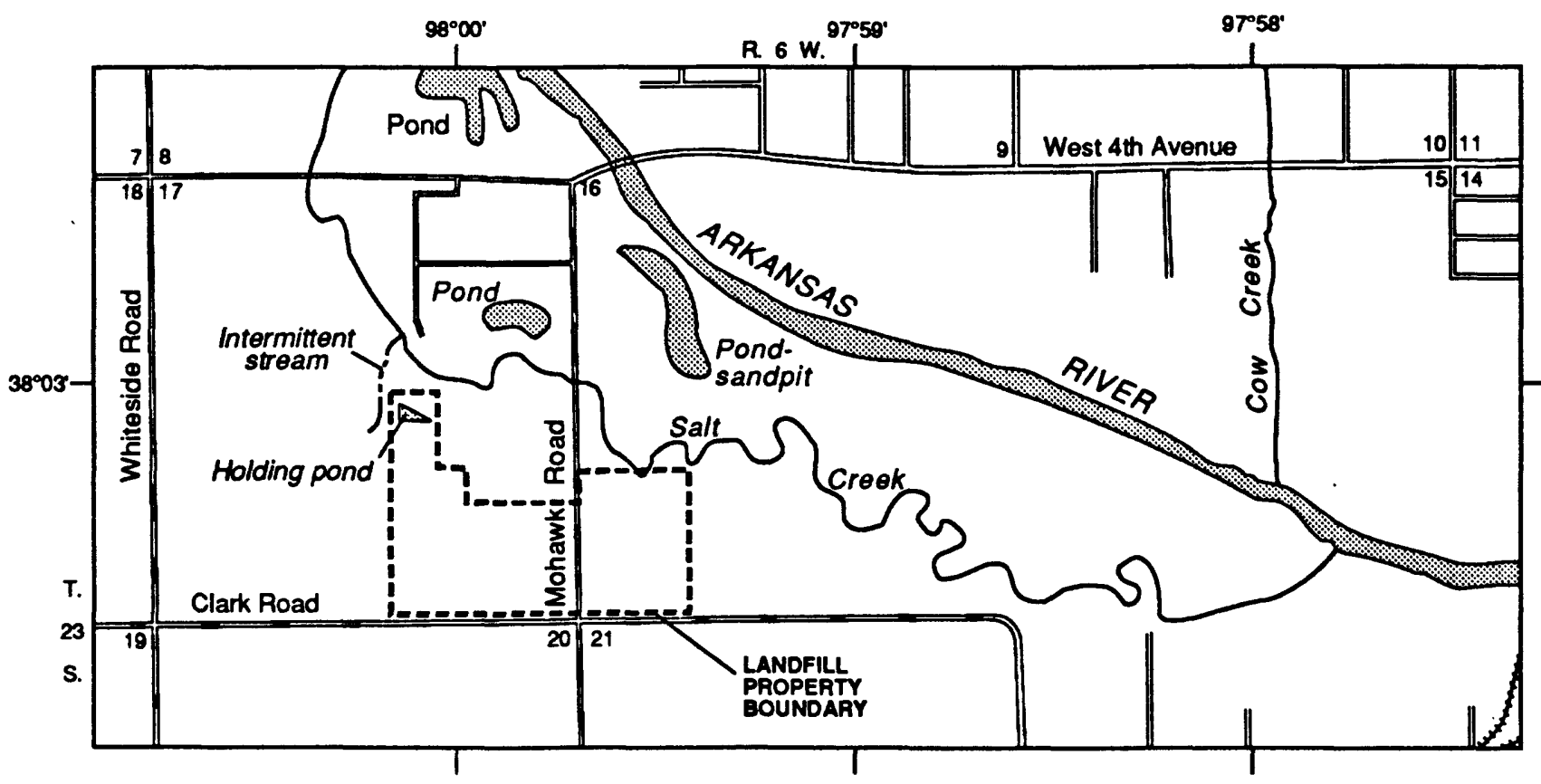

Prepared in cooperation with RENO COUNTY, KANSAS

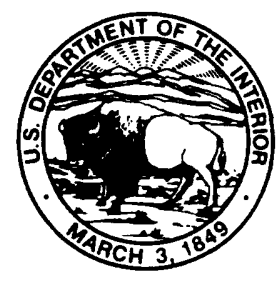


HYDROGEOLOGY AND GROUND-WATER-QUALITY CONDITIONS AT THE RENO COUNTY LANDFILL, SOUTH-CENTRAL KANSAS, 1990-91

By Brian A. Heck, Nathan C. Myers, and Dirk A. Hargadine

U.S. GEOLOGICAL SURVEY

Water-Resources Investigations Report 92-4169

Prepared in cooperation with

RENO COUNTY, KANSAS

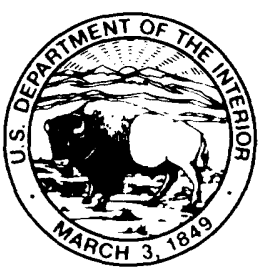

Lawrence, Kansas

1992 


\title{
U.S. DEPARTMENT OF THE INTERIOR
}

\author{
MANUEL LUJAN, JR., Secretary
}

\author{
U.S. GEOLOGICAL SURVEY
}

Dallas L. Peck, Director

For additional information write to:

District Chief

U.S. Geological Survey

Water Resources Division

4821 Quail Crest Place

Lawrence, Kansas 66049-3839
Copies of this report can be purchased from:

U.S. Geological Survey

Books and Open-File Reports

Denver Federal Center

Box 25425

Denver, Colorado 80225 


\section{CONTENTS}

Page

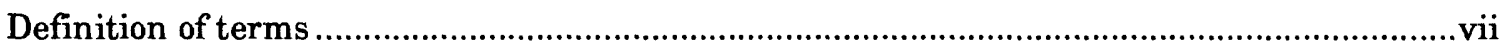

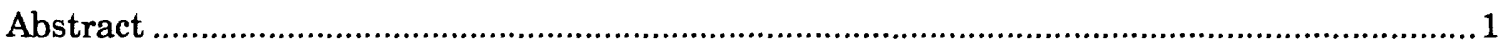

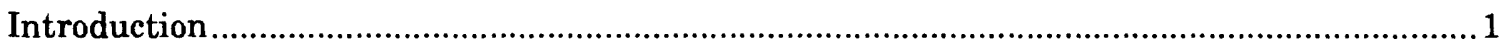

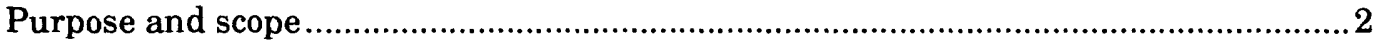

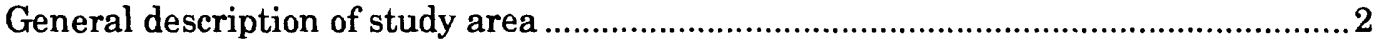

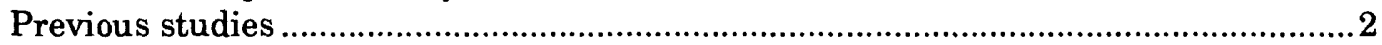

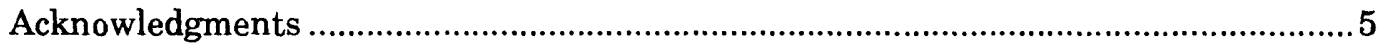

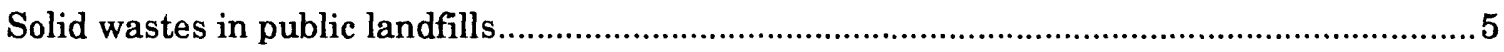

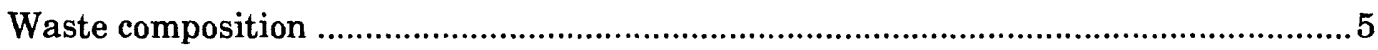

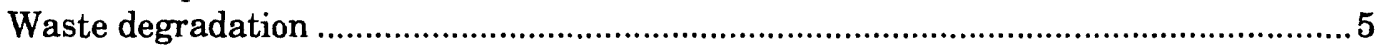

Leachate production and composition............................................................... 8

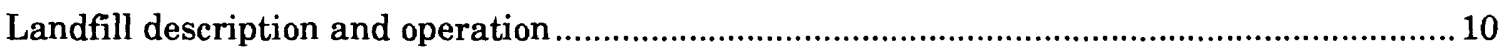

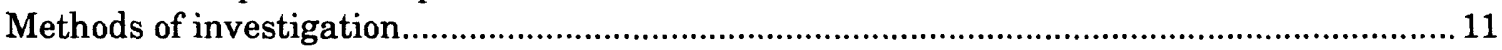

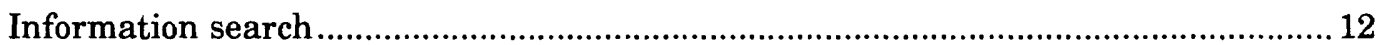

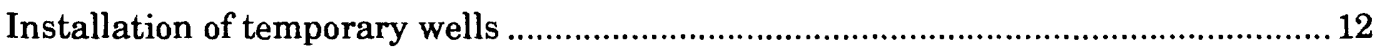

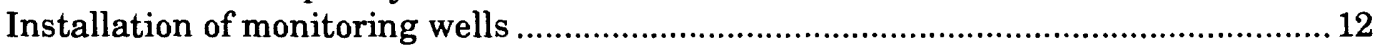

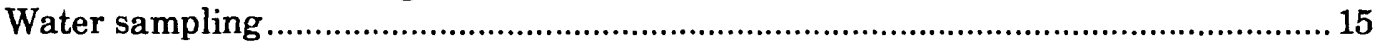

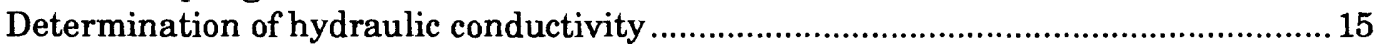

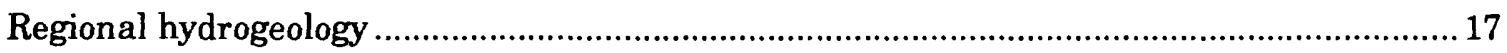

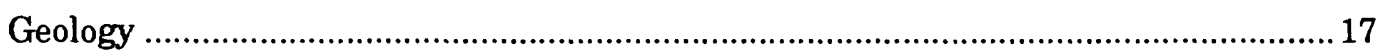

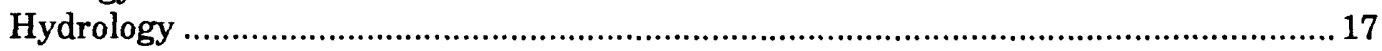

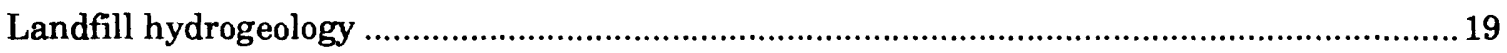

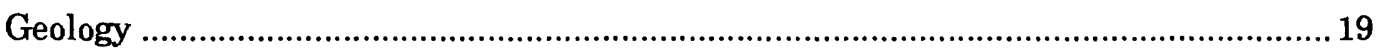

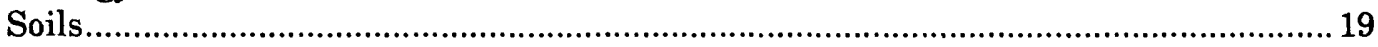

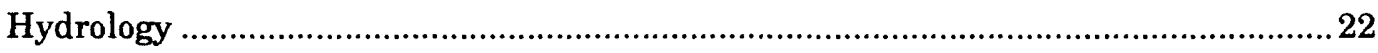

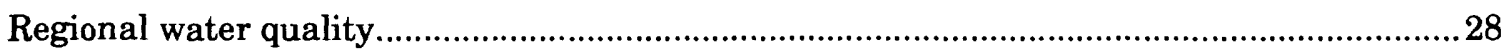

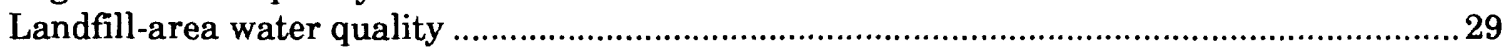

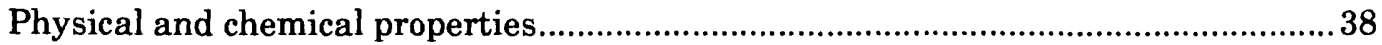

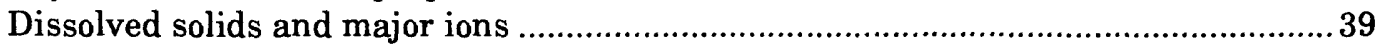

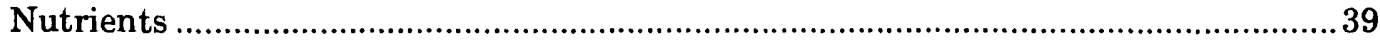

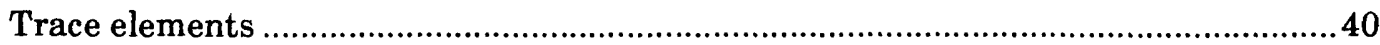

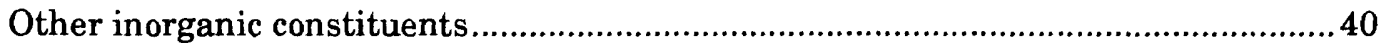

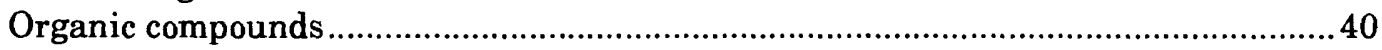

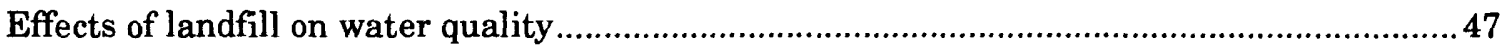

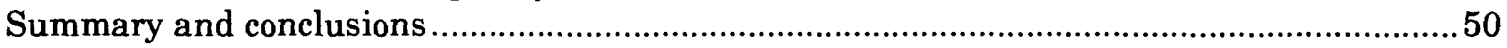

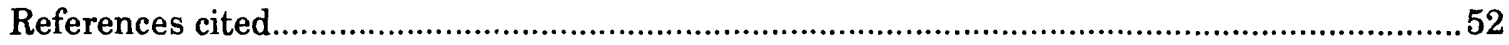




\section{ILLUSTRATIONS}

Figure 1. Map showing location of Reno County Landfill, south-central Kansas .......... 3

2. Map showing topography in vicinity of Reno County Landfill ......................... 4

3. Maps showing current land use in vicinity of Reno County Landfill and historic and current land use on landfill site

4. Graphs showing degradation phases and components of an idealized, homogeneous landfill cell

5. Map showing location of temporary, monitoring, industrial-storage, industrial-disposal, industrial-observation, and private-supply wells, surface-water sampling sites, and borehole in vicinity of Reno County Landfill .....

6. Diagram showing monitoring-well design ............................................... 14

7. Map showing surficial geology in vicinity of Reno County Landfill ................20

8. Lithologic sections of upper 200 feet in vicinity of Reno County Landfill ......21

Figures 9-13. Maps showing:

9. Soils in vicinity of Reno County Landfill

10. Potentiometric surface in Quaternary sediment, Reno County Landfill and vicinity, March 6, 1991

11. Potentiometric surface in Quaternary sediment, Reno County Landfill and vicinity, July 2 and August 4, 1986, and August 22, 1990

12. Modified Stiff diagrams of major-ion concentrations in water samples collected from monitoring and private-supply wells and surface-water sites, Reno County Landfill and vicinity, August 7-8, 1990

13. Distribution of iron and manganese concentrations in water samples, Reno

County Landfill and vicinity, August 7-8, 1990

Figure 14-18. Hydrogeologic section showing distribution of:

14. Field-determined specific-conductance values, Reno County Landfill and vicinity, August 7-8,1990

15. Concentrations of dissolved solids at 105 degrees Celsius, Reno County Landfill and vicinity, August 7-8, 1990.

16. Concentrations of 1,1-dichloroethane, indicating general location of leachate plume, Reno County Landfill and vicinity, August 7-8, 1990.

17. Concentrations of trichloroethylene, indicating general location of leachate plume, Reno County Landfill and vicinity, August 7-8, 1990

18. Concentrations of vinyl chloride, indicating general location of leachate plume, Reno County Landfill and vicinity, August 7-8, 1990

19. Concentrations of 1,2-trans-dichloroethylene, indicating general location of leachate plume, Reno County Landfill and vicinity, August 7-8, 1990 55 


\section{TABLES}

Table 1. Average monthly temperature and precipitation at Hutchinson, Kansas, 1967-90

2. Typical moisture content of newly disposed municipal solid-waste components

3. Typical physical property values and chemical-constituent concentrations in landfill leachate

4. Water-column volumes purged from wells at the Reno County Landfill before sampling in August 1990

5. Generalized section of geologic units in Reno County, Kansas

6. Water-level altitudes in temporary wells, monitoring wells, industrialobservation wells, and Salt Creek in the vicinity of the Reno County Landfill

7. Top-of-casing altitudes, total depths, and screened depths of temporary wells, monitoring wells, industrial-storage, industrial-disposal, and industrial-observation wells in vicinity of the Reno County Landfill

8. Hydraulic conductivity at the Reno County Landfill calculated from slugtest data

9. Physical properties and inorganic constituents in water samples from monitoring and private-supply wells, and Salt Creek sampling sites, Reno County Landfill and vicinity, August 7-8, 1990

10. Organic compounds detected in water samples from monitoring and private-supply wells, and Salt Creek sampling sites, Reno County Landfill and vicinity, August 7-8, 1990

11. Organic compounds detected in water samples collected August 7-8, 1990, in the vicinity of Reno County Landfill

12. Organic compounds analyzed in water samples collected from the Reno

County Landfill and vicinity....

13. Common uses of some organic compounds tentatively identified in water samples collected from the Reno County Landfill and vicinity .47 


\section{CONVERSION FACTORS AND VERTICAL DATUM}

$\begin{array}{lll}\text { Multiply } & \text { By } & \text { To obtain } \\ \text { inch } & 2.54 & \text { centimeter } \\ \text { foot } & 0.3048 & \text { meter } \\ \text { mile } & 1.609 & \text { kilometer } \\ \text { square mile } & 2.590 & \text { square kilometer } \\ \text { acre } & 0.4047 & \text { hectare } \\ \text { gallon } & 3.785 & \text { liter } \\ \text { cubic foot } & 0.02832 & \text { cubic meter } \\ \text { cubic foot per second } & 0.02832 & \text { cubic meter per second }\end{array}$

To convert temperature in degrees Fahrenheit $\left({ }^{\circ} \mathrm{F}\right)$ to degrees Celsius $\left({ }^{\circ} \mathrm{C}\right)$, use the following equation:

$$
{ }^{\circ} \mathrm{C}=\left({ }^{\circ} \mathrm{F}-32\right) / 1.8 \text {. }
$$

Sea level: In this report, "sea level" refers to the National Geodetic Vertical Datum of 1929--a geodetic datum derived from a general adjustment of the first-order level nets of the United States and Canada, formerly called Sea Level Datum of 1929. 


\section{DEFINITION OF TERMS}

Aerobic

Alluvium

Alkalinity

Anaerobic

Chemical oxygen demand

Equipotential line

Hardness

Hydraulic conductivity

Hydraulic gradient

Hydraulic head

Hydrolysis

Oxidation

pH

Porosity
Living, active, or occurring only in the presence of free oxygen.

Sediment deposited by flowing rivers.

The capacity of solutes to react with and neutralize acid in a solution.

Living, active, or occurring in the absence of free oxygen.

A measure of the quantity of chemically oxidizable material present in water.

A line in a two-dimensional ground-water flow field such that the total hydraulic head is the same for all points along the line.

A measure of the amount of calcium and magnesium carbonates dissolved in the water.

The rate of flow of water at the existing kinematic viscosity that will move through a porous medium in unit time under a unit hydraulic gradient through a unit area measured at right angles to the direction of flow. Units of hydraulic conductivity are:

$\frac{\left.\text { length }^{3} / \text { time }\right)}{\left(\text { length }^{2}\right)(\text { length/length })}\left(\right.$ for example,$\left.\frac{\left.\text { (feet }^{3} / \text { day }^{2}\right)}{\left(\text { feet }^{2}\right)(\text { feet/feet })}\right)$

but, as in this report, are commonly simplified and reported as length/time (for example, feet per day).

Rate of change in total hydraulic head per unit of distance of flow in a given direction.

Height above a stated datum of the surface of a water column that can be supported by the static pressure at a given point.

A chemical decomposition process involving the splitting of a chemical bond and the addition of the two ions that comprise water (hydrogen and hydroxide).

A process in a chemical reaction whereby an atom or molecule loses electrons.

A measure of negative logarithm of the hydrogen-ion activity, in moles per liter.

Ratio of the volume of void spaces in a rock or sediment to the total volume of the rock or sediment. 


\section{Potentiometric surface}

Redox

\section{Specific conductance}

Symbiotic

Transmissivity
A surface that represents the level to which water will rise in a tightly cased well. If the hydraulic head varies considerably with depth in an aquifer, there may be more than one potentiometric surface for that aquifer.

Reduction-oxidation chemical reactions in which electrons are transferred from one atom or molecule to another. An atom or molecule that loses electrons (thus increasing its charge) is said to be oxidized, whereas an atom or molecule that gains electrons (thus decreasing its charge) is said to be reduced. In the reaction $\mathrm{Fe}\left(\right.$ metal) $+\mathrm{Cu}^{2+} \ldots>\mathrm{Fe}^{2+}+\mathrm{Cu}$ (metal), the iron is oxidized, and the copper is reduced.

A measure of the ability of water to conduct an electrical current, which in turn is related to the concentration of ionized substances in the water.

The intimate association of two dissimilar organisms in a mutually beneficial relationship.

The capacity of an aquifer to transmit water of the prevailing kinematic velocity. The transmissivity of an aquifer is equal to hydraulic conductivity of the aquifer multiplied by the saturated thickness of the aquifer (Heath, 1982). 


\title{
HYDROGEOLOGY AND GROUND-WATER-QUALITY CONDITIONS AT THE RENO COUNTY LANDFILL, SOUTH-CENTRAL KANSAS, 1990-91
}

\author{
By
}

\author{
Brian A. Heck, Nathan C. Myers, and Dirk A. Hargadine
}

\section{ABSTRACT}

An investigation of the geology, hydrology, and water quality at the Reno County Landfill, south-central Kansas, was conducted from August 1990 to March 1991. In the vicinity of the landfill, the Ninnescah Shale of Permian age constitutes the bedrock surface and is overlain by Quaternary sand-and-gravel deposits. Overlying the sand and gravel is a clay or silty clay layer, which in turn is overlain by top soil. The sand-and-gravel deposits are between 100 to 140 feet thick. The thickness of the clay or silty clay layer varies, increasing to about $\mathbf{5 0}$ feet south of the landfill. Salt Creek is located directly north of the landfill and was a losing stream during the investigation. Potentiometric-surface maps constructed from measured water levels in temporary, monitoring, and industrial-observation wells indicated that ground-water movement is from west to east parallel to Salt Creek and the Arkansas River. The average linear velocity of the ground water was calculated to be 0.75 foot per day.

Chemical analysis of water samples from monitoring wells, supply wells, and Salt Creek at and in the vicinity of the Reno County Landfill indicates large concentrations of chloride. These large chloride concentrations contribute to larger specific-conductance values and dissolved-solids concentrations in ground water with increased proximity to Salt Creek. Leachate from both the old city and the old county sections of the landfill is the probable source of large iron and manganese concentrations in wells located on the landfill property.

Dissolved organic carbon, methylene-blue active substances, and 23 specific organic compounds were detected in water samples from the monitoring wells. Concentrations of 1,1-dichloroethane, tetrachloroethylene, trichloroethylene, and vinyl chloride in water samples from wells on the landfill property exceeded the U.S. Environmental Protection Agency's Maximum Contaminant Level (for drinking-water supplies).
The extent of downgradient movement of the organic compounds is not known, but compounds are suspected to migrate east of the landfill in the direction of ground-water flow. From previous sampling, organic compounds were detected in water from private-supply wells east of the landfill. During the investigation, organic compounds were not detected in downgradient wells MW-11, PW-2, or PW-5, and only small concentrations were detected in downgradient wells PW-3 and MW-14. Analyses of samples from these downgradient wells can be used to outline a nondetectable limit or boundary for organic-compound migration. The vertical extent of the leachate plume may be approaching bedrock, as indicated by concentrations of 1,1-dichloroethane, 1,2trans-dichloroethylene, trichloroethylene, and vinyl chloride in water samples from well MW-12. Concentrations of organic compounds in ground water decrease in the direction of ground-water flow, probably as a result of degradation, dispersion, and dilution.

\section{INTRODUCTION}

Shallow aquifers in central and eastern Kansas provide water for public and private drinking-water supplies, for irrigation and livestock, and for industrial uses. Information describing the geologic characteristics of the aquifers, the sources and directions of ground-water flow, and the chemical quality of ground and surface water is necessary for sound management of water resources. To gain information about the effects of landfills on water quality, the Kansas Department of Health and Environment (Topeka) requires all public landfills in Kansas to install ground-water monitoring systems (Charles Linn, Kansas Department of Health and Environment, oral commun., 1988). The investigation described here, conducted in cooperation with Reno County, Kansas, from August 1990 to March 1991, is one of several being conducted in Kansas by the U.S. Geological Survey that focuses on the effects of 
landfills on the quality of water in shallow aquifers. The objectives of the investigation were to determine the geology, hydrology, and water-quality conditions in the vicinity of the Reno County Landfill and to describe the effects of the landfill on shallow ground-water quality.

\section{Purpose and Scope}

This report describes the physical setting of the Reno County Landfill, the fate of waste materials in landfills, in general, and investigative methods used. Data collected during installation of temporary and monitoring wells and subsequent water-level measurements are used to describe the geology and hydrology in the vicinity of the landfill. Analysis of samples from private-supply and monitoring wells, and from a nearby creek define water-quality conditions near the landfill and the effects of the landfill on ground-water quality.

\section{General Description of Study Area}

The Reno County Landfill is located west of the City of Hutchinson in south-central Kansas (fig. 1). Reno County had a population of about 62,400 during 1990 (Institute for Public Policy and Business Research, 1991) and covers approximately 1,250 square miles. Reno County is in the physiographic region designated locally as the Great Bend Prairie (Schoewe, 1949) and is characterized by very slight topographic relief (fig. 2).

The Arkansas River and its tributaries provide the major drainage for Reno County. The southern part of Reno County is drained by the North Fork Ninnescah River and the northeastern part by the Little Arkansas River (fig. 1). These two rivers drain into the Arkansas River southeast of Reno County. Other tributaries to the Arkansas River in Reno County are Cow Creek and Salt Creek (fig. 1).

Bayne (1956) characterized Reno County's climate as subhumid with moderate precipitation, a wide range of temperature, and moderately high wind velocity. The average monthly high temperature from $1967-90$ was $80.9^{\circ} \mathrm{F}$ in July, and the average monthly low was $29.6^{\circ} \mathrm{F}$ in January. The average annual precipitation from $1967-90$ was 30.2 inches
(National Oceanic and Atmospheric Administration, 1967-90). About 50 percent of this precipitation occurred from May through August. Table 1 defines the average monthly temperature and precipitation for Hutchinson, Kansas, 1967-90.

Most water used in Reno County is derived from shallow aquifers in unconsolidated sand-and-gravel deposits. Most surface water has large concentrations of chloride and dissolved solids and generally is unsuitable for most uses (Bayne, 1956). Land use in the immediate vicinity of the landfill is cropland, pasture, industrial, and commercial (fig. $3 \mathrm{~A}$ ).

\section{Previous Studies}

No previous published reports for the Reno County landfill or the effects of the landfill on water quality are available. There have been several previous water analyses for the landfill's nine existing monitoring wells and for the private-supply wells in the immediate vicinity. This sampling of wells was done from 1986-90 (Wilson Laboratories, written commun., 1989, 1990) (Reno County, written commun., 1990). There also have been several studies of the lithology, soil type, and water-table depth for the current landfill area and the immediate vicinity regarding future landfill use (Engineering Testing Company, written commun., 1976, 1984, 1989). Industrial and special wastes disposed of in the landfill also have been recorded by Reno County for the past 10 years.

A number of authors have described the geology, hydrology, and water quality in Reno County. Williams (1946) reports on ground water in the Arkansas River valley. Williams and Lohman (1949) study the ground water and geology in south-central Kansas. Bayne (1956) evaluates the geology and ground-water resources for Reno County.

Rockers and others (1966) map soil types in Reno County for the U.S. Soil Conservation Service and describe the type of soil, location of the soil, and possible soil uses. Olson (1974) evaluates soil types in Kansas with regard to waste-disposal sites. Hathaway and others (1981) study the water quality of irrigation water derived from the Equus beds in eastern 


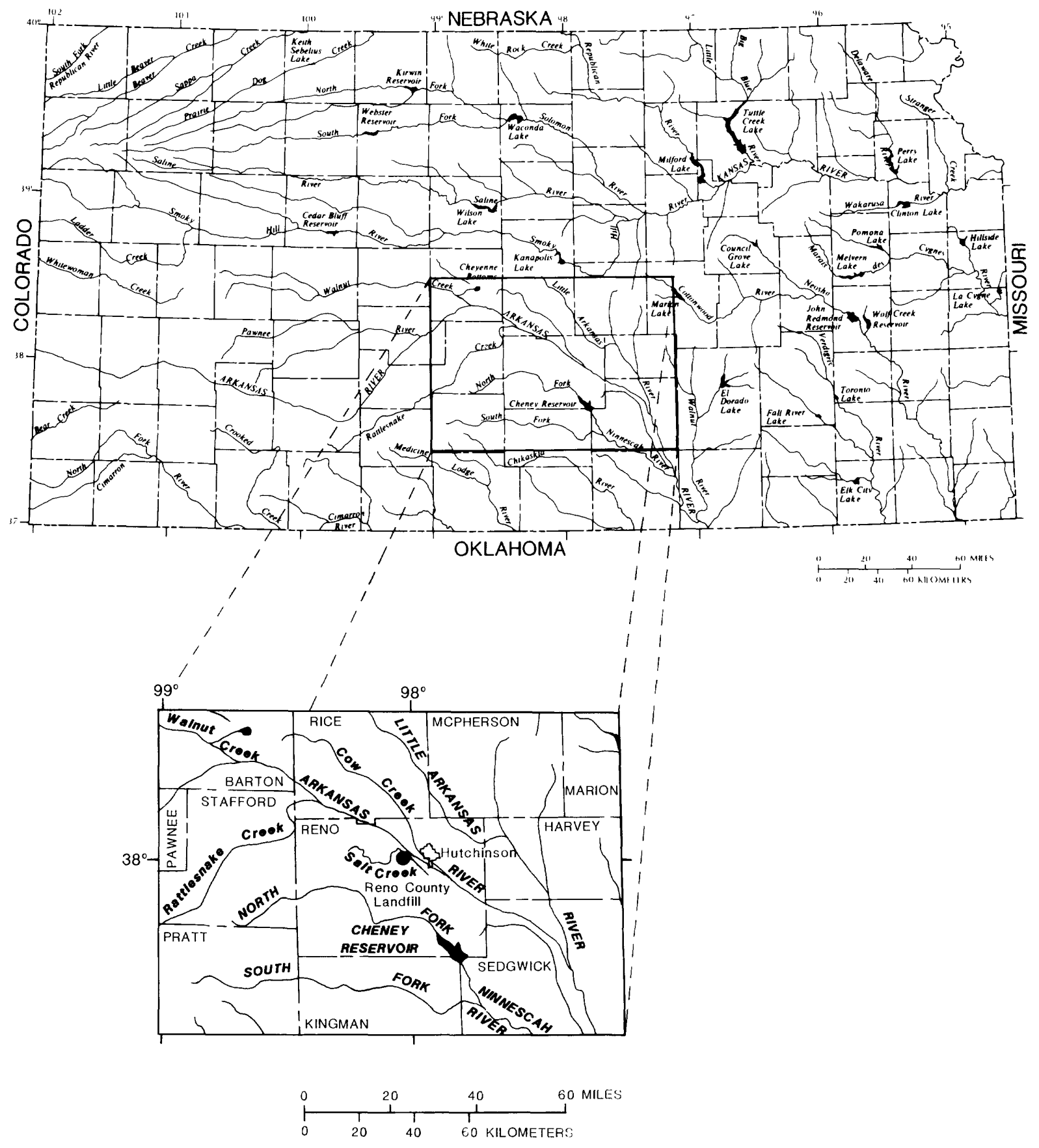

Figure 1. Location of Reno County Landfill, south-central Kansas.

Reno County. Leonard and Kleinschmidt (1976) study the potential for pollution of freshwater aquifers by saltwater intrusion due to increases in pumpage in the Little Arkansas River basin. A similar report by Gogel (1981) describes the flow of saltwater from Permian rocks into the freshwater aquifer system. Snyder and Dellwig (1961) describe plastic flowage of salt in mines.
Reed and Burnett (1985) compile the results of aquifer-performance tests done in the terrace deposits along the Arkansas River near Hutchinson. The City of Hutchinson conducted aquifer-performance tests to evaluate future water availability (Layne-Western Company, Inc., written commun., 1985). 


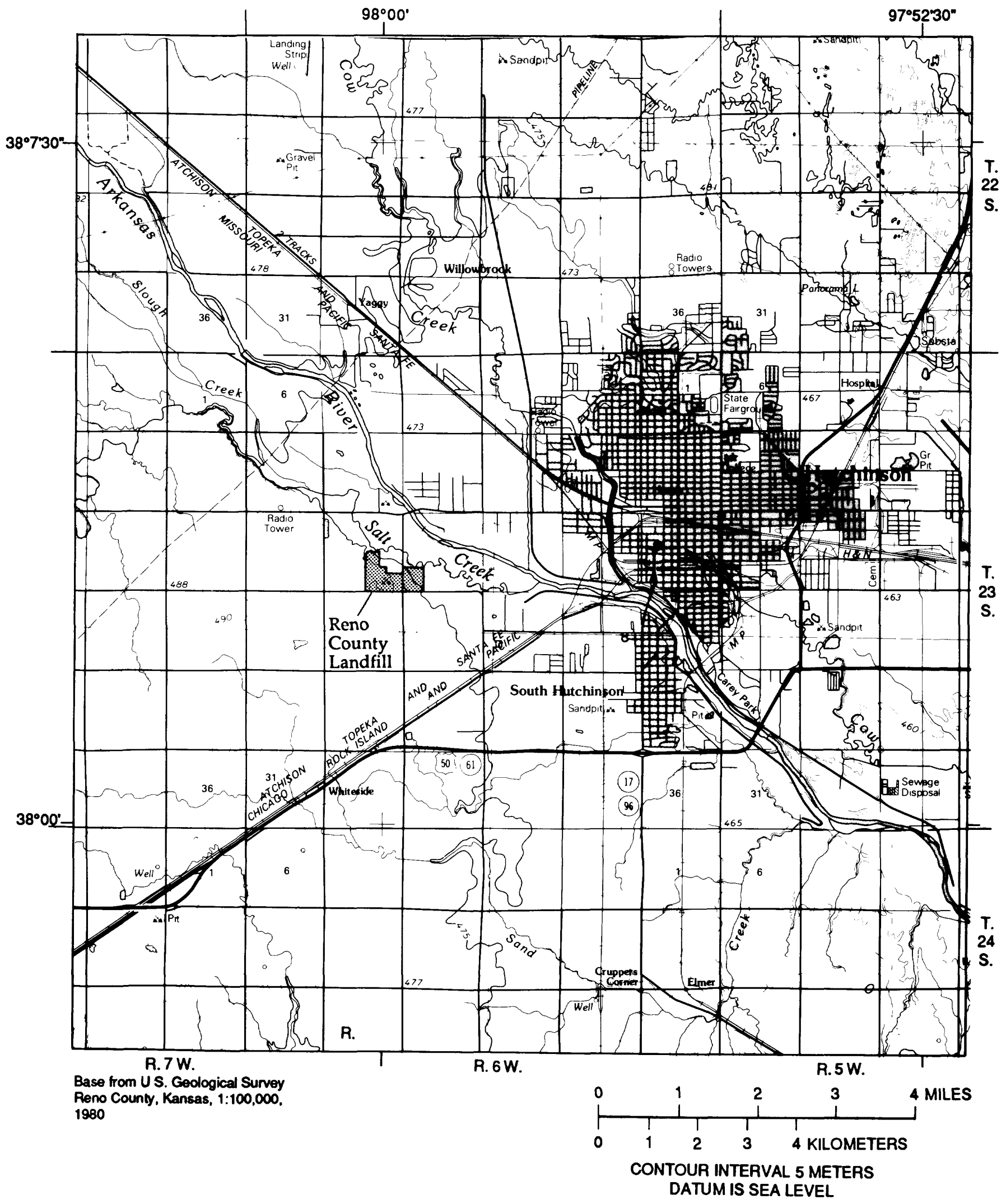

Figure 2. Topography in vicinity of Reno County Landfill. 
Table 1. Average monthly temperature and precipitation at Hutchinson, Kansas, 1967-90

[Data from National Oceanic and Atmospheric Administration, 1967-90]

\begin{tabular}{|c|c|c|c|c|c|c|c|c|c|c|c|c|}
\hline Jan. & Feb. & Mar. & Apr. & May & June & July & Aug. & Sept. & Oct. & Nov. & Dec. & \\
\hline \multicolumn{13}{|c|}{ Average temperature, in degrees Fahrenheit } \\
\hline 29.6 & 34.7 & 45.4 & 55.7 & 64.4 & 75.5 & 80.9 & 79.0 & 70.0 & 57.9 & 43.7 & 33.4 & \\
\hline \multicolumn{12}{|c|}{ Average precipitation, in inches } & Total \\
\hline 0.62 & 1.01 & 2.47 & 3.00 & 4.23 & 4.26 & 3.11 & 3.11 & 3.16 & 2.88 & 1.40 & 0.99 & 30.24 \\
\hline
\end{tabular}

\section{Acknowledgments}

The authors would like to extend appreciation to George Sugars, Reno County Engineer, for assistance in coordinating the study through his office and to Cynthia Kidd, Solid Waste Administrator, for providing information about the history and operation of the landfill. Appreciation is also due Aurelio Lamas, landfill foreman, for the use of landfill facilities for equipment storage during field work. The authors also acknowledge Gary Bontrager, A.B. Cameron, William Clark, Ralph Davis, Fred Mowery, Dr. C.T. McCoy, and OXY USA, Inc., for providing access to their property from which data were collected during the investigation.

\section{SOLID WASTES IN PUBLIC LANDFILLS}

Solid wastes are materials that are no longer of value to the individual or community and, therefore, are discarded. The following is a general discussion of solid-waste composition, solid-waste degradation, and leachate production and composition in landfills. Much of the discussion is modified from Myers and Bigsby (1989). Although the exact composition of the solid waste and chemical processes in the Reno County Landfill are not known, they can be inferred to be similar to the general compositions and chemical processes reported in the literature.

\section{Waste Composition}

Typical nationwide composition of landfill solid waste, by weight, is 45 percent paper, 15 percent food and kitchen waste, 11 percent yard and garden trimmings, 9 percent metal, 8 percent glass, 4 percent dirt, ash, and concrete, 3 percent textiles, 3 percent plastics, and 2 percent wood (Tchobanoglous and others, 1977). About 80 percent of the solid waste is combustible. Total amounts of fixed carbon, water, and volatile organic matter represent 7 , 20 , and 53 percent of the solid waste. Solid-waste composition varies because of the climate, season, recycling, demography, packaging, and marketing (Tchobanoglous and others, 1977).

\section{Waste Degradation}

About 80 percent of typical solid waste, including paper, food and kitchen waste, yard and garden trimmings, and ferrous metal, can be degraded. The other 20 percent, mostly glass, wood, rubber, plastics, and synthetic textiles, degrades very slowly (Tchobanoglous and others, 1977). Degradation processes in the landfill include biologic decomposition, solution, precipitation, sorption, ion exchange, and diffusion of gases (Baedecker and Back, 1979). Sufficient moisture content, 20 to 60 percent, is essential for significant degradation rates. The moisture content depends on the composition of the waste, the climate, the age and thickness of the landfill material, and other factors (Tchobanoglous and others, 1977). Typical moisture content for new solid waste is listed in table 2.

Degradation phases and components of an idealized, homogeneous landfill cell are represented in figure 4 (Christensen and others, 1989). Phase 1 represents the aerobic phase 
(oxidizing environment). Aerobic degradation proceeds rapidly and probably begins in easily degradable waste soon after deposition. Net products primarily are carbon dioxide and water, plus sulfate and ammonia (Baedecker and Back, 1979). The water produced by aerobic degradation increases the amount of moisture available for subsequent anaerobic degradation processes.

When oxygen is depleted by aerobic degradation, methane-generating anaerobic degradation of the organic waste begins. Anaerobic degradation dominates in the reducing environment of phases 2 through 4 (fig. 4). Phase 5 (fig. 4) is characterized by decreased methane production, increased nitrogen concentrations in the landfill gas, and aerobic zones in the upper layers of the landfill. During phase 5 , methane formation becomes minimal and nitrogen diffuses from the atmosphere into the soil. End products of the fully completed anaerobic degradation are methane, water, and carbon dioxide (Baedecker and Back, 1979).

At any specific time, individual parts of the same landfill may be in different stages of degradation. Stage and rate of degradation will vary from one landfill to another, depending primarily on moisture content but also on temperature and on local procedures for shredding, mixing, and compacting the wastes. The aerobic stage of a waste cell may be

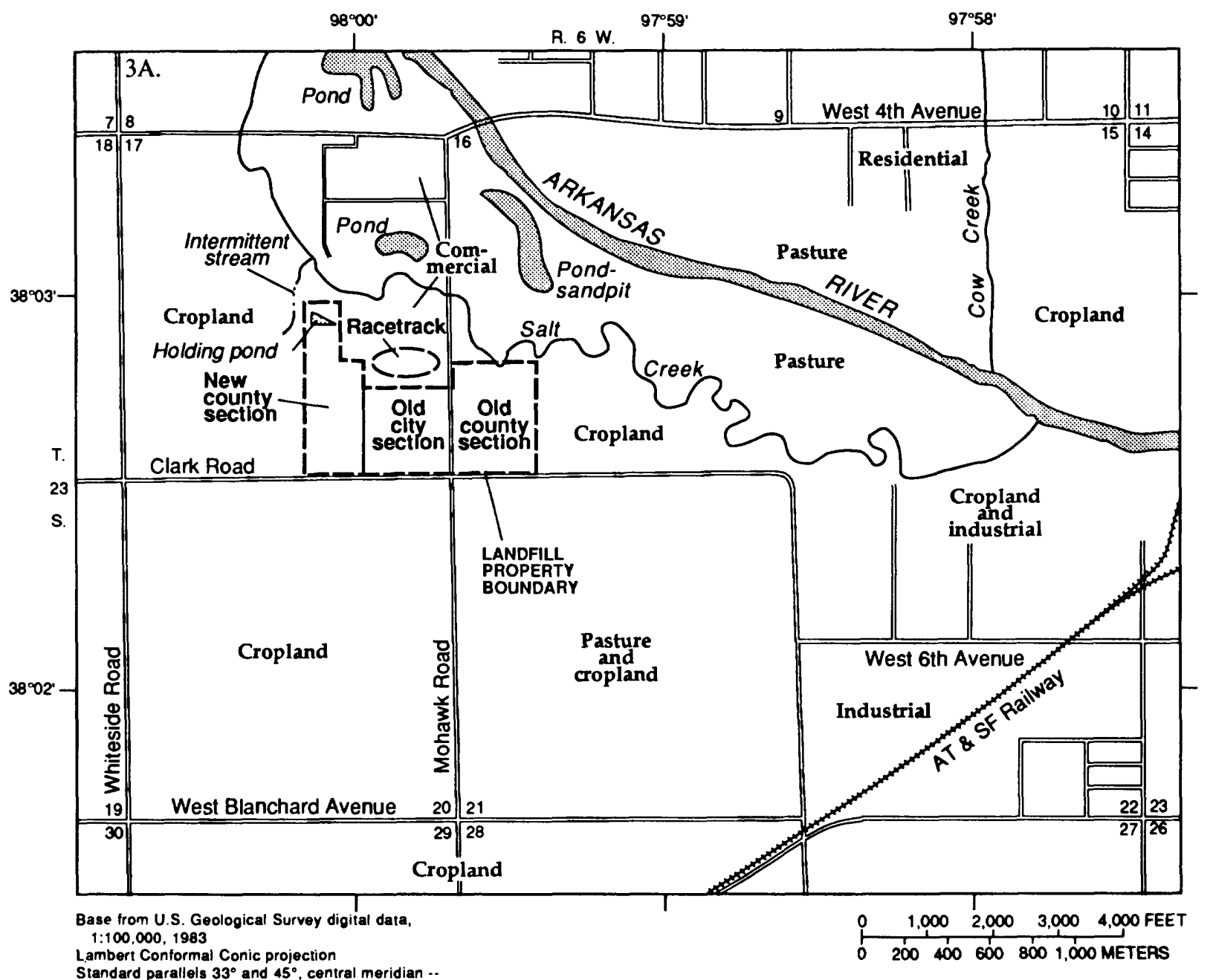

Lambert Conformal Conic projection

Standar meridian -

EXPLANATION

MW-2 MONITORING WELL AND NUMBER

Figure 3. (A) Current (1991) land use in vicinity of Reno County Landfill, (B) historic land use on landfill site, and (C) current land use (1991) on landfill site. 

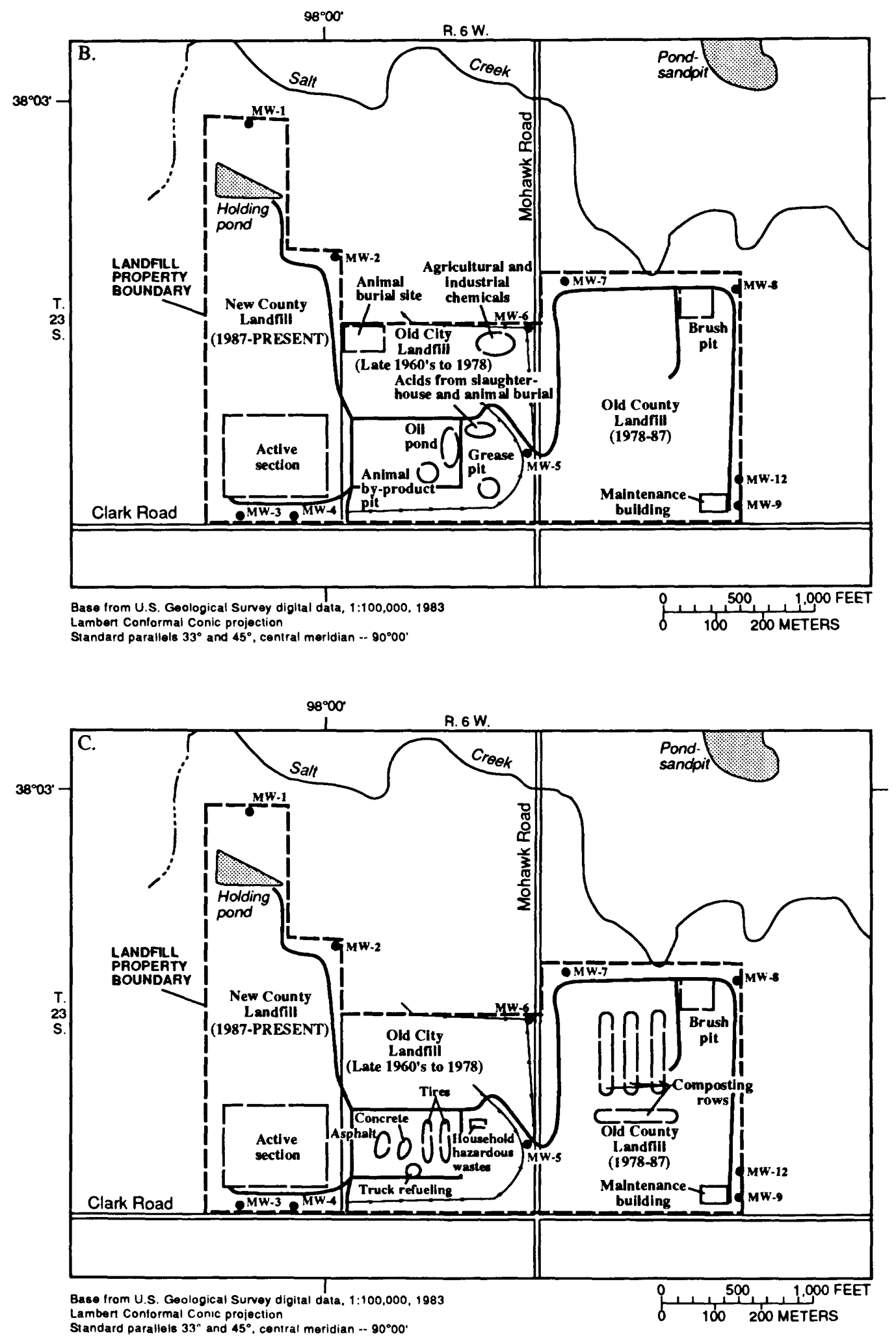

Figure 3. (A) Current (1991) land use in vicinity of Reno County Landfill, (B) historic land use on landfill site, and (C) current land use (1991) on landfill site--Continued 
Table 2. Typical moisture content of newly disposed municipal solid-waste components

[Modified from Tchobanoglous and others, 1977]

\begin{tabular}{llc}
\hline & \multicolumn{2}{c}{ Moisture, in percent } \\
\cline { 2 - 3 } \multicolumn{1}{c}{ Component } & Range & Typical \\
\hline Food waste & $50-80$ & 70 \\
Paper & $4-10$ & 6 \\
Cardboard & $4-8$ & 5 \\
Plastics & $1-4$ & 2 \\
Textiles & $6-15$ & 10 \\
Rubber & $1-4$ & 2 \\
Leather & $8-12$ & 10 \\
Garden trimmings & $30-80$ & 60 \\
Wood & $15-40$ & 20 \\
Glass & $1-4$ & 2 \\
Tin cans & $2-4$ & 3 \\
Nonferrous metals & $2-4$ & 2 \\
Ferrous metals & $2-6$ & 3 \\
Dirt, ash, brick, and other & $6-12$ & 8 \\
Municipal solid wastes & & \\
$\quad$ (composite of above & & 20 \\
components) & $15-40$ & \\
\hline
\end{tabular}

completed in a few days or weeks, and anaerobic degradation occurs quickly enough to allow significant methane production to peak within 2 years and then decline for 25 years or more (Tchobanoglous and others, 1977).

\section{Leachate Production and Composition}

Leachate is generated by the waste itself, the percolation of water through the waste, and the biological and chemical extraction of dissolved and suspended materials (Tchobanoglous and others, 1977). Paper, which comprises about 45 percent of all landfill waste, absorbs most of the water originally available in the waste. Therefore, the production and discharge of leachate from a landfill above the water table requires the infiltration of water downward from the land surface. Initially, waste is unsaturated, and most percolating water is retained by the waste, particularly paper products. Once the waste becomes nearly saturated, lateral and downward movement of leachate occurs. Solids, gases, and liquids from the waste are incorporated into the leachate as dissolved, suspended, or sorbed components that may be either miscible or immiscible. Metabolic carbon dioxide, produced by bacterial action, dissolves easily, decreasing leachate $\mathrm{pH}$. The resulting dissolution of calcium carbonate, if present, increases hardness and dissolved solids. Solvent capability of the leachate also is increased by the bacterially generated organic acids, which causes some metals in the landfill to dissolve.

Chemical processes in leachate production are oxidation, reduction, solution, precipitation, ion exchange, and sorption. In the landfill, these processes are affected to a large degree by the types of organic compounds present (Baedecker and Back, 1979). Physical processes contributing to leachate production are settlement, movement of evolved and ejected water, entrainment of colloidal and particulate material in percolating water, filtration, change of solute concentration by osmosis and concentration gradients, density separation of immiscible phases, and vertical and horizontal migration of gases. 

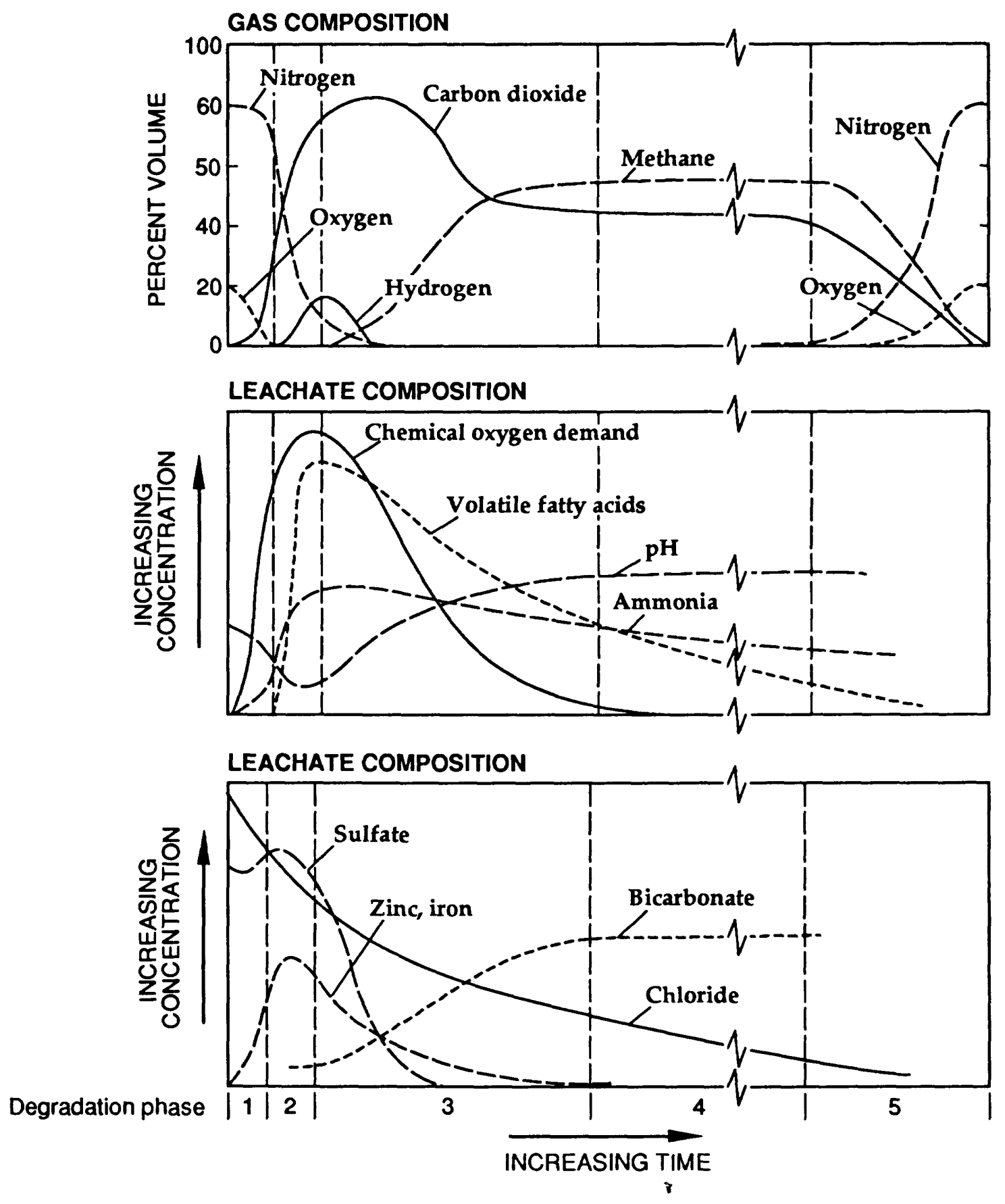

Figure 4. Degradation phases and components of an idealized, homogeneous landfill cell (modified from Christensen and others, 1989).

Leachate composition is variable. Some typical concentrations and composition ranges of the most abundant constituents are listed in table 3 . Where ranges are given, the larger values are expected in newer landfills because these are undergoing more rapid early-stage biodegradation involving acid production. Sodium and potassium tend to remain in solution, unadsorbed by clay when calcium is present. Bicarbonate is produced directly in anaerobic reactions and indirectly when carbon dioxide dissolves. Bicarbonate also is dissolved from landfill ash, soil, and rock. Sulfate, derived from ash and treatment waste, may be reduced within the landfill anaerobic environment and precipitated as ferrous sulfide or evolved as 
Table 3. Typical physical property values and chemical-constituent concentrations in landfill leachate

[Concentrations in milligrams per liter $(\mathrm{mg} / \mathrm{L})$ except as noted]

\begin{tabular}{|c|c|c|c|c|}
\hline $\begin{array}{l}\text { Property or } \\
\text { constituent }\end{array}$ & $\begin{array}{l}\text { Steiner and } \\
\text { others, } 1971\end{array}$ & $\begin{array}{c}\text { U.S. } \\
\text { Environmental } \\
\text { Protection Agency, } \\
1973\end{array}$ & $\begin{array}{c}\text { U.S. } \\
\text { Environmental } \\
\text { Protection Agency, } \\
1975\end{array}$ & $\begin{array}{l}\text { Tchobanoglous } \\
\text { and others, } 1977\end{array}$ \\
\hline $\begin{array}{l}\text { Specific } \\
\text { conductance }^{1}\end{array}$ & $\cdots$ & $\cdots$ & $6,000-9,000$ & --- \\
\hline $\mathrm{pH}^{2}$ & $4.0-8.5$ & $3.7-8.5$ & $5.2-6.4$ & 6.0 \\
\hline $\begin{array}{l}\text { Chemical } \\
\text { oxygen demand }\end{array}$ & $100-51,000$ & $0-89,520$ & $16,000-22,000$ & 18,000 \\
\hline Hardness, total & $200-5,250$ & $0-22,800$ & $3,500-5,000$ & 3,500 \\
\hline Calcium (Ca) & ---- & $5-4,080$ & $900-1,700$ & ---- \\
\hline Magnesium (Mg) & $-\cdots$ & $16.5-15,600$ & $160-250$ & --- \\
\hline Sodium $(\mathrm{Na})$ & $100-3,800$ & $0-7,700$ & $450-500$ & 500 \\
\hline Potassium (K) & --- & $2.8-3,770$ & $295-310$ & 300 \\
\hline $\begin{array}{l}\text { Alkalinity, total } \\
\text { as } \mathrm{CaCO}_{3}\end{array}$ & ---- & $0-20,850$ & $800-4,000$ & 3,000 \\
\hline Sulfate $\left(\mathrm{SO}_{4}\right)$ & $25-500$ & $1-1,826$ & $400-650$ & 300 \\
\hline Chloride $(\mathrm{Cl})$ & $100-2,400$ & $34-2,800$ & $600-800$ & 500 \\
\hline $\begin{array}{l}\text { Dissolved solids, } \\
\text { total }\end{array}$ & --- & $0-42,276$ & $10,000-14,000$ & $-\cdots$ \\
\hline Nitrate, total as $\mathrm{N}$ & $20-500$ & $0-1,416$ & $-\cdots$ & 5.6 \\
\hline Phosphate (P) & $5-130$ & $0-154$ & -.-- & --- \\
\hline Iron $(\mathrm{Fe})$ & $200-1,700$ & $0.2-5,500$ & $210-325$ & 60 \\
\hline Lead $(\mathrm{Pb})$ & --- & $0-5.0$ & 1.6 & $-\cdots$ \\
\hline Manganese (Mn) & --- & $0.06-1,400$ & $75-125$ & --- \\
\hline Zinc $(Z n)$ & $1-135$ & $0-1,000$ & $10-30$ & --- \\
\hline
\end{tabular}

1 Values in microsiemens per centimeter at 25 degrees Celsius.

2 Values in standard units.

hydrogen sulfide gas, but sulfate otherwise is nonreactive. Chloride is nonreactive, and its concentrations in leachate vary primarily because of dilution. Nitrogen is present mostly as ammonia because of conditions stemming from anaerobic degradation and the presence of dissolved iron (Apgar and Langmuir, 1971). Iron and manganese commonly are present in leachate in large concentrations. These constituents can be derived from wastes and also from oxide coatings and cements in soil and rock.

Leachate can contain trace elements such as cadmium, chromium, cobalt, copper, lead, mercury, nickel, strontium, and zinc in detectable concentrations. Other environmentally significant elements detected in landfill leachate include arsenic, boron, selenium. These elements can occur naturally in the environment or can be derived from the landfill wastes. Elements present at concentrations above natural background are likely derived from municipal and industrial wastes or dissolution of natural compounds by leachate.

\section{LANDFILL DESCRIPTION AND OPERATION}

The Reno County Landfill is located west of Hutchinson, Kansas, and covers about 140 acres (figs. 2 and 3). The landfill is nearing capacity, 
and additional land to the south is being considered for landfill operations. The landfill can be divided into three distinct parts--the old city section, the old county section, and the new county section (fig. 3A). The old city section occupies about 40 acres, the old county section about 50 acres, and the new county section about 50 acres. The surrounding areas are used for cropland, pasture, rural-residence, commercial, and industrial purposes (fig. 3A).

The old city landfill section, the center section of the present-day landfill area (fig. 3A), began operation in the late 1960's. This section was operated as an open dump by the city of Hutchinson until 1975, when Reno County assumed the operation (Cynthia Kidd, Reno County Solid Waste Administrator, oral commun., 1990). The dump most likely started at a depth of 10 to 15 feet below the original land surface and was completed 15 to 20 feet above land surface in 1978. The material deposited in the old city section was comprised of household waste, chemicals from farms and industries, oil and grease, animal carcasses, animal by-products, and acids from slaughter houses (fig. 3B). The area has been capped by 2 feet of cover material consisting mostly of clay and has native grass planted on the slopes. The area currently (1991) is used to dispose of asphalt, concrete, and tires (fig. 3C). The asphalt, concrete, and tires are in piles located on top of the completed section and will be used to construct berms around any new sections of the landfill (Cynthia Kidd, oral commun., 1990). There is an above-ground fuel tank used to refuel landfill vehicles and a new building for temporary storage of household hazardous wastes such as motor oil, paint, batteries, anti-freeze, and other hazardous materials (fig. $3 C$ ). These wastes will be recycled, if possible, or transported to a hazardous-waste landfill on an annual basis (Cynthia Kidd, oral commun., 1990).

The next part of the landfill to be used was the old county section, which was active from 1978-87. This section is located directly east of the old city section (fig. 3A) and was operated as a sanitary landfill with compacted trash, a daily cover, and 3 feet of final cover material. A burn pit for brush is located in the northeast corner of this section (fig. 3C). Waste similar to that in the old city section was buried in this part of the landfill. According to the industrial-waste logs, paint, oil, scrubber, and laundry sludges along with salt waste, drilling mud, asbestos, and small quantities of pesticides and laboratory chemicals have been placed in this section of the landfill. Placement of these industrial wastes was random, and exact locations are unknown. The wastes in the old county section were placed in trenches excavated to an altitude of about 1,547 feet above sea level, about 10 feet below the original land surface. The old county section was completed in 1987, and the top of the clay cover material is about 1,582 feet above sea level. The slopes of this section were planted with fescue and brome grass, and the top with oats and sudan grass. Piles of yard waste currently are being composted in rows on top of this completed section (fig. $3 \mathrm{C}$ ).

The new county section is located in the far western part of the landfill area (fig. 3A). This section currently (1991) is being operated using the ramp method of sanitary landfilling. The first layer of waste is being placed from about 25 feet below land surface to the land surface and is almost completed, with the extreme southern part yet to be filled. A second layer has been placed on top of some of the completed first layer. The remainder of the open area on top of the completed first layer will be used as the next disposal area. A third layer is being considered, as well as more land located to the south of the current landfill area. A holding pond is located in the northern part of this section (fig. 3B). The pond was constructed using compacted soil. The holding pond is used to hold drainage from landfill runoff and septic-tank discharge. The Reno County Landfill log for industrial waste indicates that grease, drilling mud, paint sludge, oil sludge, laundry sludge, scrubber sludge, salt waste, and laboratory chemicals have been placed in the new county section.

\section{METHODS OF INVESTIGATION}

There were four phases of investigation of the Reno County Landfill. The first was an initial information-gathering phase for the general area and the landfill. The information gathered included the landfill's history, the geology and hydrology of the area, data for existing monitoring and other wells in the vicinity of the landfill. The second phase consisted of two parts: (1) installation of 
temporary wells to determine the hydrology and geology, and (2) monitoring-well installation to collect water samples. Locations for these wells were selected on the basis of the geologic and hydrologic information from the temporary and existing monitoring wells. In the third phase, water samples were collected and analyzed from monitoring wells, private-supply wells, and selected surface-water sites. This report, which concludes the fourth phase, presents and interprets data obtained during this study.

\section{Information Search}

Prior to any work onsite, a search of published literature and files of the Kansas Department of Health and Environment (Topeka), Kansas Geological Survey (Lawrence), and Reno County (Hutchinson) was completed. Preliminary estimates of lithology and groundwater flow directions at the landfill site were made on the basis of previous geologic and hydrologic information. This information was useful for planning well locations, datacollection activities, and material requirements.

\section{Installation of Temporary Wells}

Boreholes for four temporary wells (fig. 5) were drilled using 3 1/4-inch inside-diameter hollow-stem augers. A steel plate was placed in the auger bit to prevent sediment from clogging the auger bit and flights while drilling. To prevent an upward surge of formation sediment and water into the hollow augers when the bottom plate was knocked out, the auger flights were filled with potable water from the city of South Hutchinson. This created equal hydrostatic pressure inside and outside the auger bit and allowed the auger flights to be removed easily after the well was set. The temporary wells were cased with polyvinyl-chloride (PVC) pipe that had flush-threaded joints, a capped bottom, and a 5 -foot screened section with 0.010 -inch slots.

Once the bottom plate was knocked out and the well set at the specified depth, the augers were pulled up from around the screen and casing, allowing the formation sediment to cave in up to the water table. The remaining open hole was filled with auger cuttings. Temporary wells TW-1, TW-2, and TW-3 (fig. 5) were all drilled to a depth of about 95 feet to determine geologic information, but only well TW-1 was completed at 90 feet. Wells TW-2, TW-3, and TW-4 were completed at 50, 34, and 32 feet. After temporary wells TW-1 and TW-2 were installed, the top-of-casing altitudes were determined by a level survey with reference to two of the landfill's existing monitoring wells, MW-1 and MW-3. Wells TW-1 and TW-2 were placed at an assumed upgradient location to confirm that the previous water levels measured in the landfill's nine existing monitoring wells indicated the correct direction of ground-water flow. Water levels were measured with a steel tape to the nearest 0.01 foot.

Geologic information was noted while drilling all temporary and monitoring wells. Gamma logging was performed on all temporary wells and monitoring wells installed by the U.S. Geological Survey to confirm the subsurface geology from the driller's logs. After sufficient water-level data were collected, all temporary wells were pulled, and the holes sealed with bentonite grout.

\section{Installation of Monitoring Wells}

Five monitoring wells were installed with hollow-stem augers with bottom plates. A 3 1/4-inch inside-diameter (6 5/8-inch outside diameter) auger was used for wells MW-10, MW-11, and MW-12 (fig. 5), and 2-inch inside-diameter PVC well casing and screen were installed. A 6 1/4-inch inside diameter (9 7/8-inch outside diameter) auger was used for wells MW-13 and MW-14, and 4-inch inside-diameter well screens and casings were installed. The casings and screens, except for well MW-13, were PVC pipe with flush-threaded joints (no glue was used). Well MW-13 had a 5-foot, 4-inch stainless-steel screen.

The procedure for the installation of the monitoring wells was similar to that of the temporary-well installation. During the removal of the augers, natural formation sediment was allowed to collapse around the casing to a point at least 5 feet above the screen. Next, 3/8-inch bentonite chips were added to provide a seal. Formation sediment then was allowed to collapse up to a depth of about 10 feet below the land surface. Next, $3 / 8$-inch bentonite chips were added to within 18 inches of the land surface, and finally a concrete pad with a 


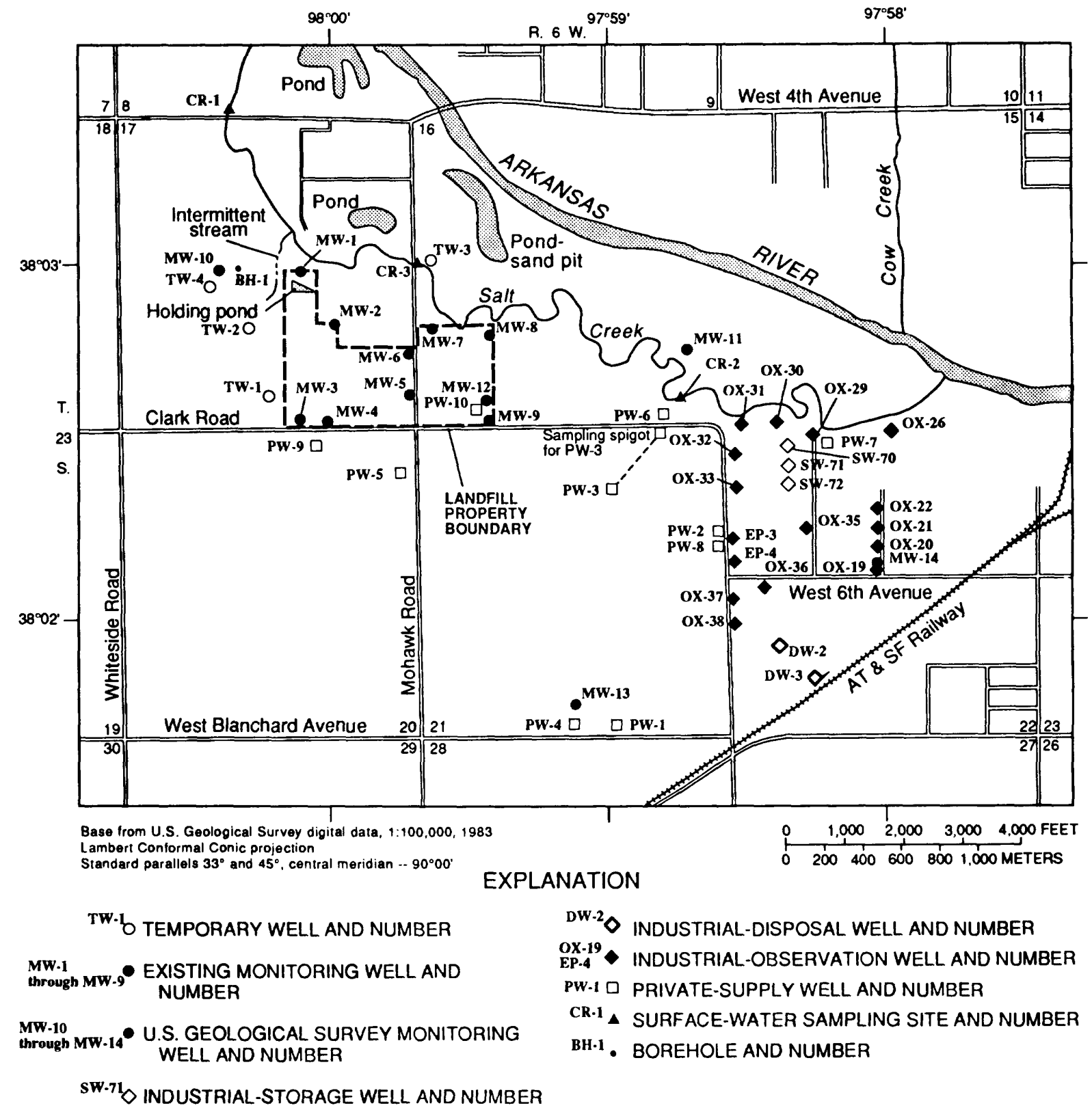

Figure 5. Location of temporary, monitoring, industrial-storage, industrial-disposal, industrial-observation, and private-supply wells, surface-water sampling sites, and borehole in vicinity of Reno County Landfill.

protective casing and locking well cap were set around the well casing (fig. 6). The wells were developed immediately to ensure that most of the fine-grained sediment and water used in drilling were removed from around the well screens.

To avoid potential cross contamination between wells or from other sources, all equipment was rinsed with a high-pressure jet of potable water, scrubbed with a low-phosphate detergent solution, and rinsed with potable water prior to installation of each monitoring well (wells MW-10 through MW-14). From previous water-quality analyses (Wilson Laboratories, written commun., 1989, 1990; Reno County, written commun., 1990), the ground-water quality within, the landfill boundary had detectable concentrations of organic constituents. With this information, a 
Protective casing

(6-inch or 8-inch polyvinyl-chloride pipe set in concrete pad, extending about 36 inches above ground level)

\section{Concrete pad}

( 2 feet diameter $\times 4$ inches, minimum)

\section{Well casing}

(Schedule-40 polyvinylchloride pipe, threaded, flush coupled, no glue or joint solvent)

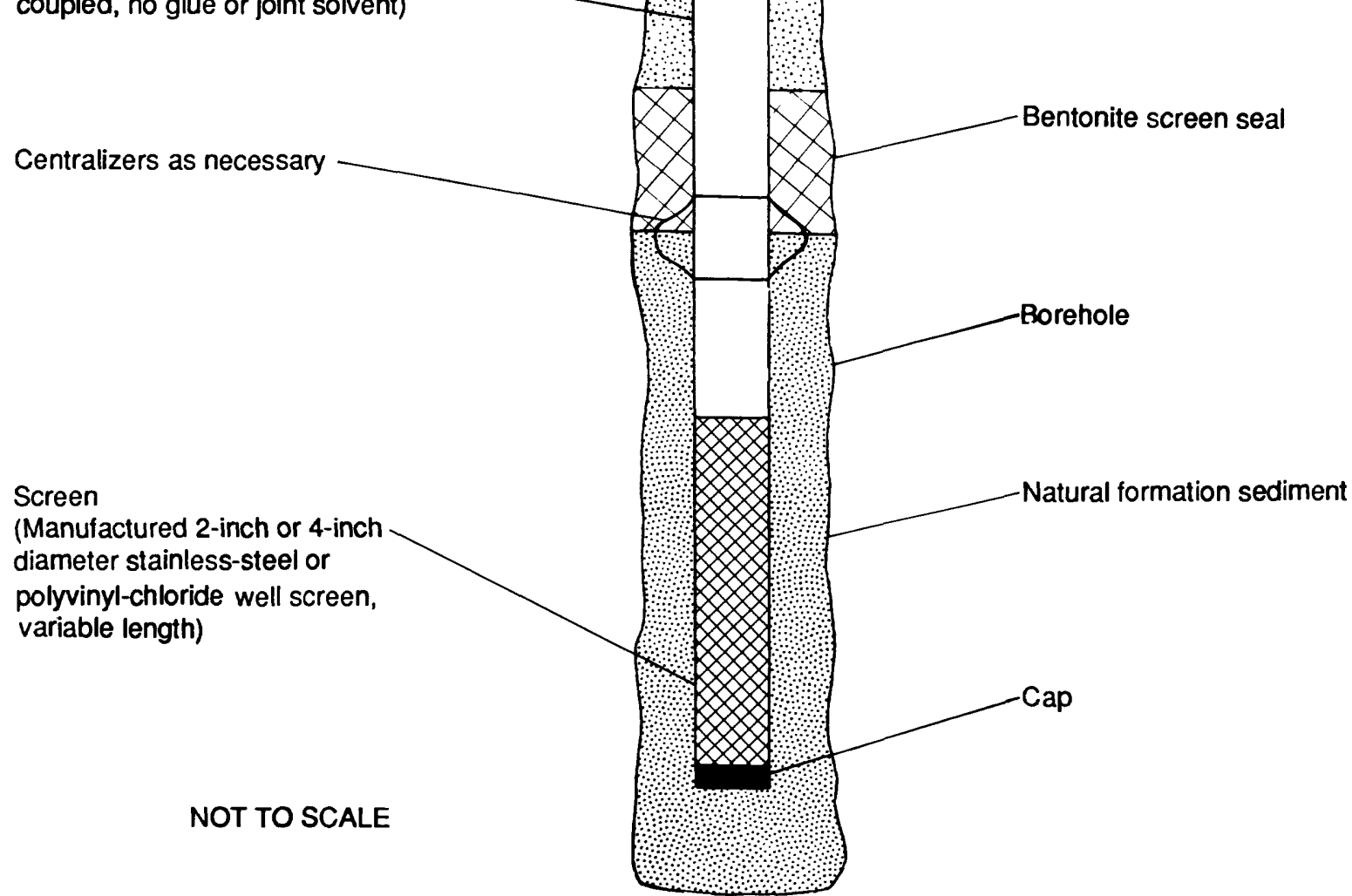

Figure 6. Monitoring-well design. 
Table 4. Water-column volumes purged from wells at the Reno County Landfill before sampling in August 1990

$[--$, not determined $]$

\begin{tabular}{|c|c|c|c|c|}
\hline Well (fig. 5) & $\begin{array}{l}\text { Nominal diameter } \\
\text { of well }{ }^{1} \text { (inches) }\end{array}$ & $\begin{array}{l}\text { Length of water } \\
\text { column in well } \\
\text { casing (feet) }\end{array}$ & $\begin{array}{l}\text { Volume of water in } \\
\text { well }^{2} \text { (gallons) }\end{array}$ & $\begin{array}{l}\text { Volume of water } \\
\text { purged }^{3} \text { (gallons) }\end{array}$ \\
\hline MW-5 & 4 & 19 & 13 & 65 \\
\hline MW-8 & 4 & 19 & 13 & 65 \\
\hline MW-9 & 4 & 15 & 10 & 50 \\
\hline MW-10 & 2 & 8 & 2 & 10 \\
\hline MW-11 & 2 & 21 & 4 & 20 \\
\hline MW-12 & 2 & 71 & 12 & 60 \\
\hline MW-13 & 4 & 7 & 5 & 25 \\
\hline MW-14 & 4 & 8 & 6 & 30 \\
\hline PW-1 ${ }^{4}$ & -- & -- & -- & -- \\
\hline PW-2 ${ }^{4}$ & -- & -- & -- & -- \\
\hline PW-3 ${ }^{4}$ & 4 & -- & -- & - \\
\hline PW-4 $4^{4}$ & 4 & -- & - & -- \\
\hline PW-5 ${ }^{4}$ & 4 & -- & - & - \\
\hline
\end{tabular}

1 The actual inside diameter of a 2 -inch well casing is 2.067 inches. The actual inside diameter of a 4 -inch well casing is 4.022 inches.

2 The equation used for calculating the volume of water in a well is:

$$
V=\left[\pi\left(\frac{I D}{24}\right)^{2}\right] 7.48 H
$$

where $\quad V \quad$ is volume of water in the well, in gallons;

ID is the inside diameter of the well casing, in inches;

$H \quad$ is the height of the water column in the well, in feet; and

7.48 is a conversion factor from cubic feet to gallons.

3 The volume of water purged from each well was about five times the volume of water in the well.

${ }^{4}$ All residential wells sampled were pumped 20 to 30 minutes before the samples were collected. 
sequence for installing the monitoring wells was used to ensure the least possibility of cross contamination. The upgradient well was installed first, then the farthest downgradient well and next farthest downgradient until well MW-12 was installed within the landfill boundary.

\section{Water Sampling}

On August 7-8, 1990, eight monitoring wells, five private-supply wells, and two creek sites were sampled. Of the eight monitoring wells sampled, five wells were installed by the U.S. Geological Survey (wells MW-10 through MW-14), and three were existing landfill monitoring wells (wells MW-5, MW-8, MW-9) (fig. 5). The private-supply wells sampled were wells PW-1, PW-2, PW-3, PW-4, and PW-5 (fig. 5). Two samples were collected from Salt Creek, one upstream and one downstream of the landfill (sampling sites CR-1 and CR-2, fig. 5). Sample collection began with the upgradient well (well MW-10) and ended with the well with the largest previously determined concentrations of organic compounds (well MW-9).

Water levels and total depths in all monitoring wells were measured to the nearest 0.01 foot with a steel tape. The tape was cleaned with distilled water before use. Each monitoring well was purged of at least five water-column volumes to ensure that water samples collected were representative of the aquifer. The volume of water to be purged from each well was determined from water-level and total-depth measurements (table 4). All monitoring wells, except for wells MW-13 and MW-14, were purged with pre-cleaned positive-displacement hand pumps. Water samples were collected from the spigots of the pre-cleaned hand pumps. Wells MW-13 and MW-14 had electric positive-displacement pumps that were thoroughly cleaned with a low-phosphate detergent solution, rinsed twice with potable water, and placed in plastic while being transported.

The sampling procedure for the private-supply wells was different than that for the monitoring wells. Because water levels were not measured in these wells, the faucet closest to the well was allowed to run 20 to 30 minutes before a water sample was collected. Each creek sample was collected at the midpoint of the flow in the creek and at a depth halfway between the creek bed and water surface.

Water samples from wells were collected in the following order: (1) volatile organic compounds, (2) semivolatile organic compounds, (3) dissolved organic carbon and dissolved common ions, and (4) dissolved trace elements. Care was taken not to aerate the water when collecting the samples. The samples for chemical oxygen demand, dissolved nutrients, and dissolved trace elements were preserved with chemicals. All samples, except anion and trace-metal samples were chilled and maintained at $4^{\circ} \mathrm{C}$. Common ion, nutrient, and trace-elements samples were filtered onsite through a 0.45 -micrometer filter, and dissolved organic carbon samples were filtered onsite through a 0.2-micrometer silver filter. Both types of filters were pre-flushed onsite with about $\mathbf{5 0 0}$ milliliters of sample water before collecting the sample to be analyzed. Specific conductance, $\mathrm{pH}$, water temperature, and alkalinity measurements were determined at the time of sample collection. Two creek samples (sampling sites CR-1 and CR-2) were processed in the same order as just described. Samples for volatile organic compounds from Salt Creek were not collected.

Water samples were mailed to the U.S. Geological Survey water-quality laboratory. Constituents were analyzed according to U.S. Geological Survey methods for determination of inorganic substances (Fishman and Friedman, 1989) and organic substances in water (Wershaw and others, 1987).

\section{Determination of Hydraulic Conductivity}

Estimates of hydraulic conductivity of the aquifer material were determined from slug tests. Slug tests were performed on wells TW-2, TW-3, MW-10, and MW-12. For each slug test, a pressure transducer was lowered through a specially designed sealing well cap to a point 10 feet or less below the static water surface. The well then was pressurized with nitrogen gas to depress the water level within the well to a point above the pressure transducer. The pressure and water level in the well was stabilized for about 5 minutes before the 
Table 5. Generalized section of geologic units in Reno County, Kansas ${ }^{1}$

[Modified from Bayne, 1956]

\begin{tabular}{|c|c|c|c|c|c|c|}
\hline \multirow{2}{*}{ System } & \multirow{2}{*}{ Series } & \multicolumn{3}{|c|}{ Subdivision } & \multirow{2}{*}{ Thickness } & \multirow{2}{*}{ Physical character } \\
\hline & & Stage & Formation & Member & & \\
\hline \multirow{10}{*}{ 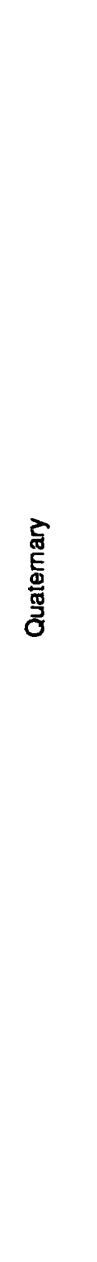 } & \multirow{10}{*}{ 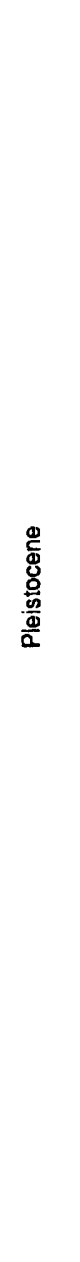 } & \multirow{2}{*}{ Holocene } & \multicolumn{2}{|c|}{ Alluvium } & $0-60$ & Silt, sand, and gravel in stream valleys. \\
\hline & & & \multicolumn{2}{|c|}{ Dune sand } & $0-120$ & Medium and fine sand in upland areas. \\
\hline & & \multirow[b]{2}{*}{ Wisconsinan } & \multirow{4}{*}{ Sanborn } & Peoria silt & $0-15$ & Eolian silt. \\
\hline & & & & $\begin{array}{l}\text { Wisconsinan } \\
\text { terrace } \\
\text { deposits }\end{array}$ & $0-130$ & Silt, sand, and gravel. \\
\hline & & \multirow{2}{*}{ lllinoian } & & $\begin{array}{l}\text { Loveland } \\
\text { silt }\end{array}$ & $0-15$ & Eolian and water-laid silt. \\
\hline & & & & $\begin{array}{l}\text { Crete sand } \\
\text { and gravel }\end{array}$ & $0-40$ & Silt, sand, and gravel. \\
\hline & & \multirow{4}{*}{ 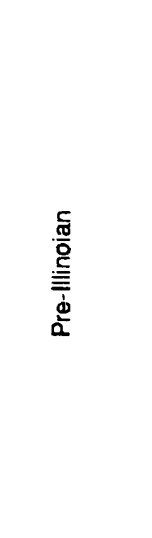 } & \multirow[b]{2}{*}{ Meade } & $\begin{array}{l}\text { Sappa } \\
\text { silt }\end{array}$ & $0-40$ & $\begin{array}{l}\text { Silt and very fine sand; contains Pearlette } \\
\text { volcanic ash lentil. }\end{array}$ \\
\hline & & & & $\begin{array}{l}\text { Grand Island } \\
\text { sand and } \\
\text { gravel }\end{array}$ & $0-100$ & Sand and gravel and minor amounts of silt. \\
\hline & & & \multirow{2}{*}{ Blanco } & $\begin{array}{l}\text { Fullerton } \\
\text { silt }\end{array}$ & $0-30$ & Sand and clay and minor amounts of sand. \\
\hline & & & & $\begin{array}{l}\text { Holdrege } \\
\text { sand and } \\
\text { gravel }\end{array}$ & $0-110$ & $\begin{array}{l}\text { Sand and gravel and minor amounts of silt } \\
\text { and clay. }\end{array}$ \\
\hline \multirow{4}{*}{ 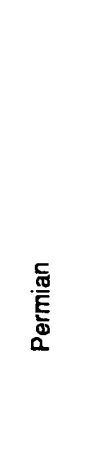 } & \multirow{4}{*}{ 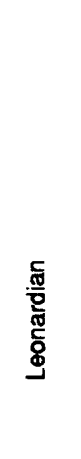 } & \multicolumn{3}{|c|}{ Harper Sandstone } & $0-200$ & Red siltstone and very fine silty sandstone. \\
\hline & & \multicolumn{3}{|c|}{ Stone Corral Formation } & $0-20$ & $\begin{array}{l}\text { White and light-gray anhydrite and } \\
\text { dolomite. }\end{array}$ \\
\hline & & \multicolumn{3}{|c|}{ Ninnescah Shale } & 0.300 & $\begin{array}{c}\text { Red and green-gray shale, siltstone, and } \\
\text { very fine silty sandstone. }\end{array}$ \\
\hline & & \multicolumn{3}{|c|}{ Wellington Formation } & $0-700$ & $\begin{array}{l}\text { Gray to blue-gray shale and thin } \\
\text { interbedded calcareous zones; contains } \\
\text { thick Hutchinson Salt Member. }\end{array}$ \\
\hline
\end{tabular}

1 The stratigraphic nomenclature is that of the Kansas Geological Survey. 
pressure was suddenly released. Pressure-transducer readings were recorded for a 2- to 20-minute duration starting when pressure was released from the well. Hydraulic conductivity was calculated using the Hvorslev method (Hvorslev, 1951; Fetter, 1988) and automated numerical algorithm (Kemblowski and Klein, 1987).

The slug-test data were analyzed by two methods. The first method was the Hvorslev method (Hvorslev, 1951; Fetter, 1988) for a saturated, unconfined aquifer with a partially penetrating well screen. The second method used an automated numerical algorithm (Kemblowski and Klein, 1987), based on the procedure for slug-test analysis developed by Bouwer and Rice (1976). Primary assumptions about these methods are that the aquifer material is isotropic and homogeneous. Results of slug-test analyses are given in table 8 in the "Landfill Hydrogeology" section of this report.

\section{REGIONAL HYDROGEOLOGY}

The descriptions of geology and hydrology for Reno County that follow provide the reader with a framework for the more detailed discussion of landfill hydrogeology later in this report.

\section{Geology}

The regional geology consists of rocks of Permian age with unconsolidated sand-andgravel deposits of Pleistocene age overlying the Permian rocks in the valleys and uplands. Eolian silt and sand deposits of Pleistocene age also occur in the uplands. Table 5 shows a generalized section of the geologic units in Reno County.

Permian rocks in Reno County include the Wellington Formation, Ninnescah Shale, Stone Corral Formation, and Harper Sandstone. The Wellington Formation, which includes the thick Hutchinson Salt Member, does not crop out in Reno County. The Ninnescah Shale overlies the Wellington Formation and crops out in the northeastern and southeastern parts of the county and along the valley of the North Fork Ninnescah River. The Ninnescah Shale consists of red and green-gray shale, siltstone, and very fine sandstone (Bayne, 1956). The Stone Corral
Formation crops out along the North Fork of the Ninnescah River in the south-central and southeastern part of the county. The Harper Sandstone overlies the Stone Corral Formation and is exposed along the hills of the North Fork of the Ninnescah River. The general bedrock slope for the county is to the east.

Three major periods of erosion and deposition occurred during the Pleistocene in Reno County. The pre-Illinoian, Illinoian, and Wisconsinan Stages of the Pleistocene all had periods of downcutting and deposition. Wisconsinan terrace deposits are present in the major river valleys and probably are due to valley cutting and filling during early and late Wisconsinan glaciation (Bayne, 1956). The terrace deposits consist mainly of sand, gravel, silt, and small amounts of clay. Alluvial deposits consist of Holocene and Wisconsinan sand and gravel. This alluvium occupies stream channels cut into the Meade Formation and Wisconsinan terrace deposits (Bayne, 1956).

\section{Hydrology}

The surface-water drainage for Reno County is provided by the Arkansas River and its tributaries. Water-table contours for 1956 (Bayne, 1956) indicate that the direction of ground-water flow in the Pleistocene sediment and near-surface Permian rocks is towards the Arkansas River in the north and towards the North Fork Ninnescah River in the south. The water-table slope generally follows the land-surface slope. This creates a ground-water flow direction that generally is eastsoutheasterly. Local variation in the direction of regional flow may occur due to local variations in the dip of Permian rocks or because of local recharge and discharge areas. The thickness of Pleistocene sediment varies due to changes in stream erosion and deposition and also from dissolution of salt deposits in the underlying Hutchinson Salt Member. The saturated thickness of Pleistocene sediment ranges from zero in the south-central part of the county to 320 feet where the Arkansas River leaves the county in the eastern part. Generally, the saturated thickness is greatest in the river valleys and where the bedrock is deepest.

Ground-water recharge in Reno County mainly occurs by infiltration of precipitation 
and also by seepage from rivers during high-flow periods. The relatively flat terrain and the permeability of the sand-and-gravel deposits allow for appreciable ground-water recharge from precipitation. A study done by Williams and Lohman (1949) for similar deposits in Sedgwick and Harvey Counties to the east and southeast indicates that about 20 percent of the precipitation reaches the ground-water table. Ground-water discharge for the region is in the form of evaporation, transpiration, well pumpage, and seepage into streams and rivers. Due to the shallow depth to ground water in the Arkansas River valley, evaporation and transpiration may be a major discharge for this area (Bayne, 1956).

\section{LANDFILL HYDROGEOLOGY}

\section{Geology}

The landfill is located in Quaternary terrace deposits, which underlie and are adjacent to the Arkansas River alluvium (fig. 7). The terrace deposits generally consist of silt, sand, and gravel layers with a maximum thickness of about 140 feet. The terrace and alluvial deposits characterize sediment in the Arkansas River valley. The valley trends southeasterly, and the landfill is located on the southern edge (fig. 7). The landfill is excavated into a clay or silty clay layer that overlies the sand-and-gravel aquifer. The topography of the landfill varies, with an altitude difference between the southeast corner and the southwest corner of 40 feet. Lithologic sections of the upper 200 feet in the vicinity of the landfill (fig. 8) show that excavation and filling has changed the topography in the area and created a new high point. The lithology for the area includes a bedrock layer of Ninnescah Shale, a sand-and-gravel layer, a clay or silty clay layer overlying the sand-and gravel layer, and top soil at the surface. The top soil layer is discussed in the next section.

The depth to bedrock is not precisely known. Bedrock was not encountered in wells TW-1, TW-2, and TW-3 that were drilled to about 95 feet. An estimate of depth to bedrock for the landfill area ranges from 100 to 140 feet. This estimate was made from lithologic logs of industrial-storage and disposal wells to the southeast of the landfill that intersect the Ninnescah Shale. However, bedrock was encountered at depths less than 35 feet in wells TW-4 (32 feet), MW-2 (12.5 feet), and MW-10 (32 feet), and in borehole BH-1 (34.5 feet) in the area northwest of the landfill (fig. 5).

A layer of sand and gravel overlies the bedrock. The top of this layer has an altitude of 1,530 to 1,550 feet above sea level, as shown in all three lithologic sections (fig. 8). The exact thickness of this layer is not known but, from industrial-storage and disposal well logs, is estimated to range from 100 to 140 feet thick.

On the basis of lithologic and gamma logs, the clay or silty clay layer varies in thickness from zero at well TW-3 to about 50 feet at well MW-4. Lithologic logs indicate that this clay-rich layer increases in thickness to the south and southwest of the landfill. Lithologic logs from wells MW-3 and MW-4 indicate that the thickness of the clay-rich layer increases to about 50 feet in the southwest corner of the landfill and decreases north of the landfill toward the Arkansas River.

\section{Soils}

The type of soil in and around a landfill may be an important factor in determining the potential for leachate to reach underlying aquifers. Finer grained soils, such as clay and silt, can decrease infiltration of precipitation, increase surface runoff, and naturally attenuate any leachate through chemical reactions and soil-particle sorption. Because the Reno County Landfill has been excavated well below the soil horizon into the clay-rich layer, this layer's physical and chemical characteristics are the primary controlling factors in leachate migration. The clay-rich layer is used as a source of daily cover material.

Soils in the vicinity of the Reno County Landfill have been described and mapped by the U.S. Soil Conservation Service (Rockers and others, 1966) and are shown in figure 9. The major soil types found surrounding the landfill area are Naron fine sandy loam, Vanoss silt loam, Farnum loam, Shellabarger-Farnum complex, Wann fine sandy loam, and Slickspots soils. Most of these soils are considered to be relatively fine-grained soils located in upland areas. Loam soils contain 7 to 27 percent clay, 28 to 50 percent silt, and less than 52 percent sand 


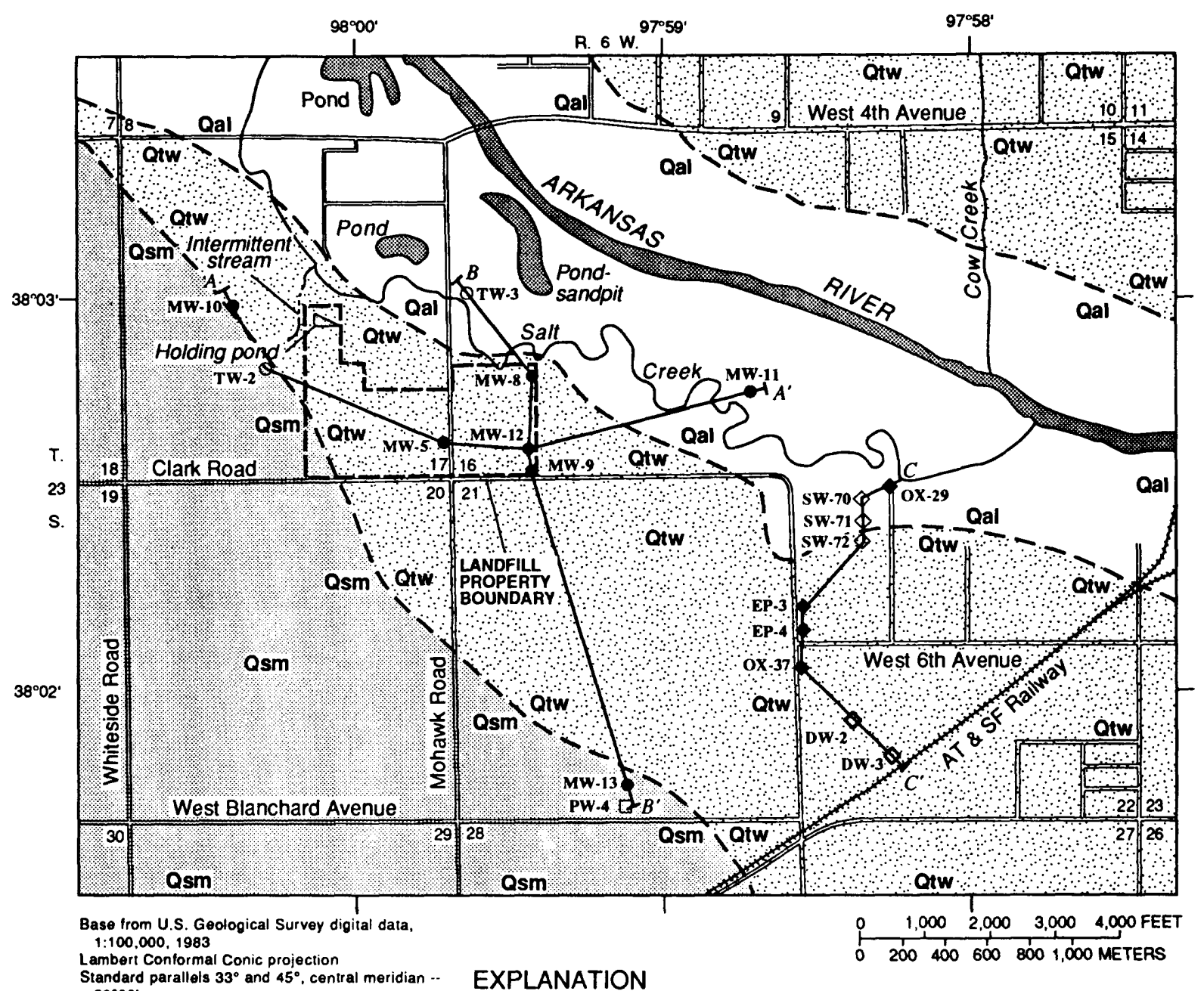

Standard parallels $33^{\circ}$ and $45^{\circ}$, central meridian -- EXPLANATION

Qal QUATERNARY ALLUVIUM--Sand, gravel,
and silt along stream valleys. Yields large
quantities of water to wells in major valleys
and moderate quantities in tributary valleys
QUATERNARY TERRACE DEPOSITS--
Consist of silt, sand, and gravel. Yield large
quantities of water to wells along major streams
QUATERNARY SANBORN AND MEADE
FORMATIONS-Consist of eolian silt, sand,
and gravel. Yield large quantities of water to
wells

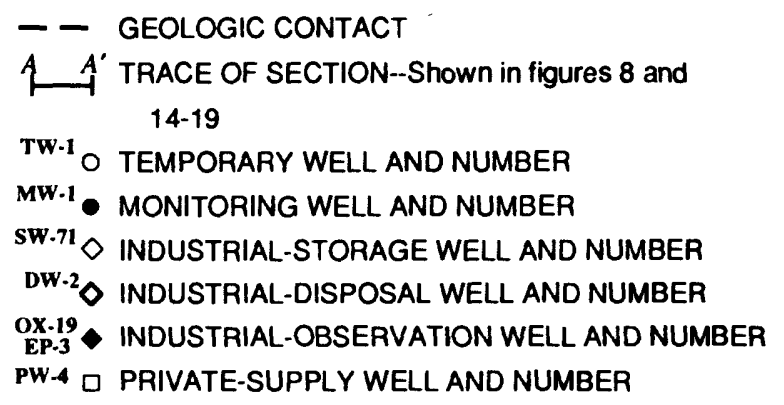

Figure 7. Surficial geology in vicinity of Reno County Landfill (modified from Bayne, 1956, plate 1).

(U.S. Department of Agriculture, 1957). There are various types of loams, depending on the percentage of sand, silt, and clay in the soil. 

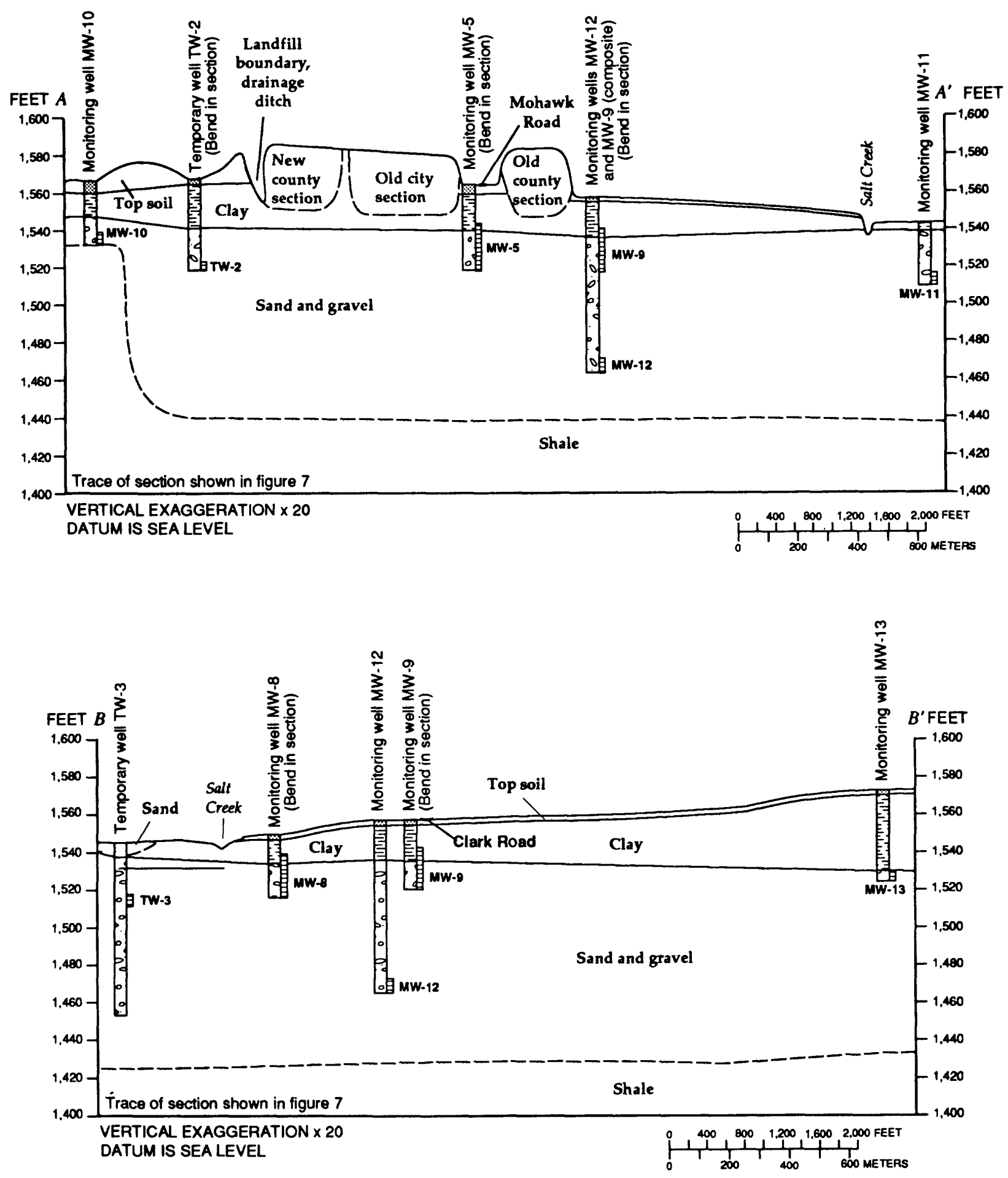

Figure 8. Lithologic sections of upper 200 feet in vicinity of Reno County Landfill. 


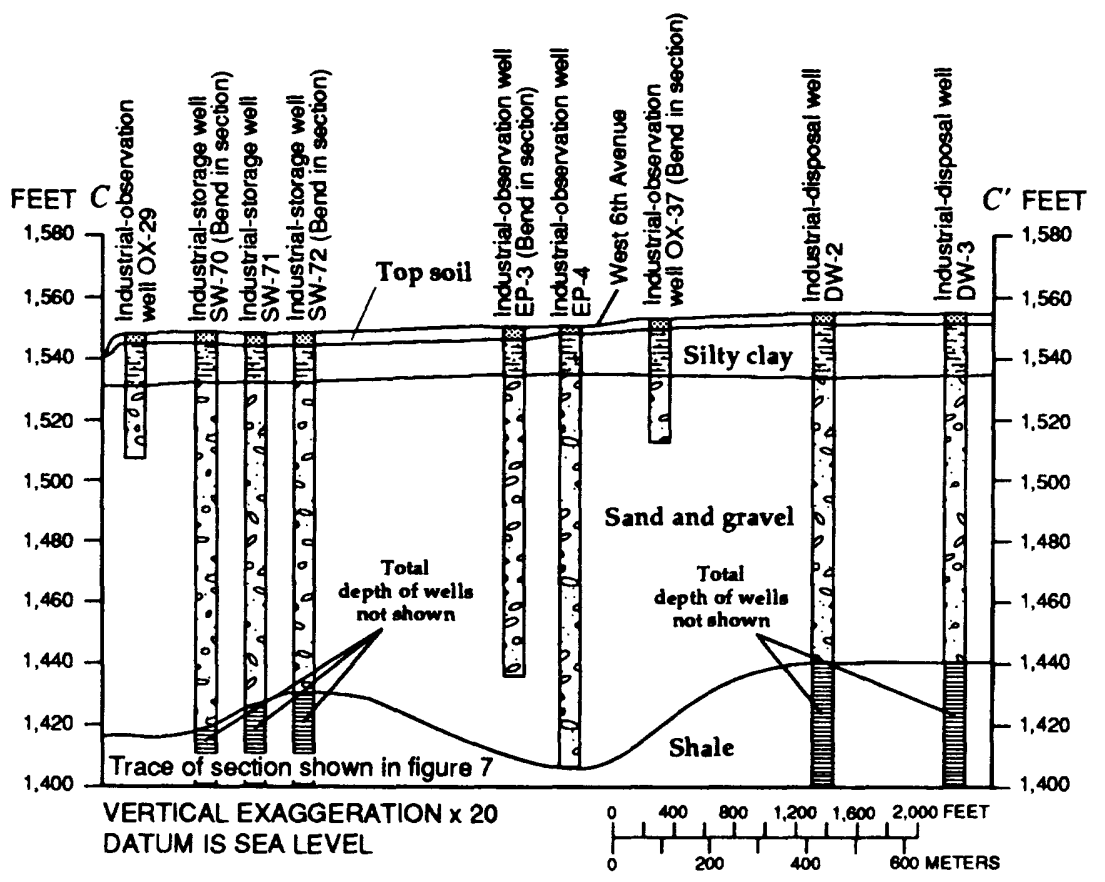

EXPLANATION
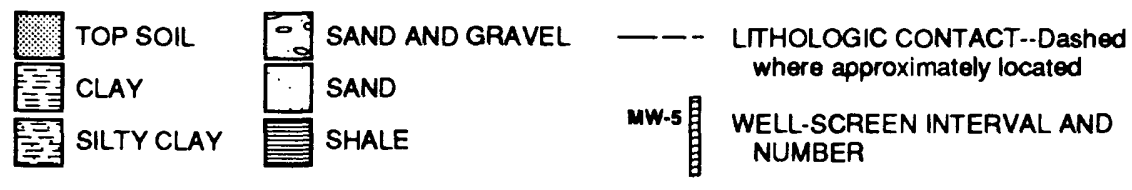

Figure 8. Lithologic sections of upper 200 feet in vicinty of Reno County Landfill--Continued

\section{Hydrology}

Surface-water bodies in the immediate vicinity of the landfill are Salt Creek to the north of the landfill and the holding pond in the northwest corner of the landfill property (fig. 3 ). There also is an intermittent stream directly northwest of the landfill area (fig. 3). Salt Creek flows from northwest to southeast and is a losing stream, as determined by water levels in well TW-3 and sampling site CR-3 for August 22, 1990, and March 6, 1991, and a seepage investigation of the creek on September 12, 1990. Because well TW-3 is the closest well to Salt Creek, its water levels were compared to those at sampling site CR-3. The water levels in well TW-3 were more than 4 feet below the water level of the creek; therefore, the creek was not gaining water from the shallow aquifer (tables 6 and 7). During periods of increased precipitation and infiltration, Salt Creek may function as a gaining stream. For the seepage investigation, the upstream discharge of Salt Creek was 3.61 cubic feet per second (sampling site CR-1), and the downstream discharge was 2.92 cubic feet per second (sampling site CR-2). Sampling sites CR-1 and CR-2 (fig. 5) are about 2.5 miles apart. The holding pond (fig. 3) contains surface runoff from the landfill. On the west side of the landfill, there is a drainage ditch (fig. 8) where water accumulates after it rains. Periodically, this water is pumped out of the ditch and into the holding pond.

Ground-water movement beneath the landfill is toward the east approximately parallel to Salt Creek and the Arkansas River (figs. 10 and 11). The direction of movement was determined by a network of temporary, monitoring, and industrial-observation wells in which water levels were measured and then used to create maps of the potentiometric surface. The direction of ground-water flow 


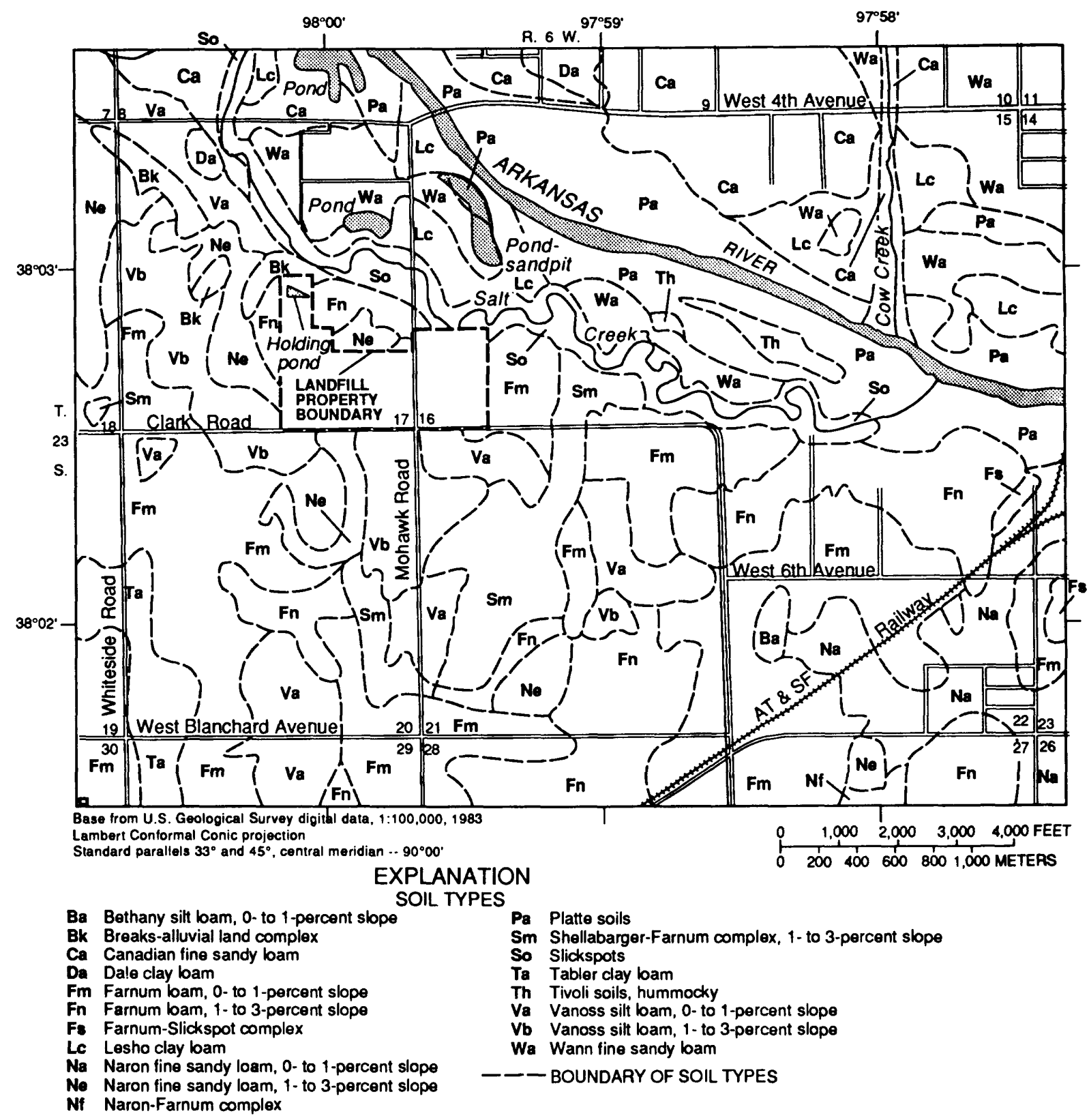

Figure 9. Soils in vicinity of Reno County Landfill (modified from Rockers and others 1966).

generally is perpendicular to the potentiometric contours. Water-level measurements were made in July and August 1986, August 1990, and March 1991 (table 6). Water levels that were measured in July and August 1986 (table 6) from the nine existing monitoring wells on the landfill also indicate an easterly direction of water movement across the landfill (figs. 11A and 11B).
Hydraulic conductivity is the capacity of a permeable medium to transmit water, with the density and viscosity of water at the prevailing conditions being considered. The actual velocity of the water through the aquifer depends on the hydraulic conductivity, the hydraulic gradient, and the porosity of the aquifer material. The velocity is expressed by the following equation: 
Table 6. Water-level altitudes in temporary wells (TW), monitoring wells (MW), industrial observation wells (OX), and Salt Creek (CR) in the vicinity of the Reno County Landfill

[Datum is sea level. --, not determined]

\begin{tabular}{|c|c|c|c|c|}
\hline \multirow[b]{2}{*}{$\begin{array}{l}\text { Well or creek } \\
\text { sampling site } \\
\text { (fig. 5) }\end{array}$} & \multicolumn{4}{|c|}{ Water-level altitude (feet) } \\
\hline & $\begin{array}{c}7 / 02 / 86^{1} \\
\text { (fig. 11A) }\end{array}$ & $\begin{array}{c}8 / 04 / 86^{1} \\
\text { (fig. 11B) }\end{array}$ & $\begin{array}{c}8 / 22 / 90 \\
\text { (fig. 11C) }\end{array}$ & $\begin{array}{c}\text { 3/06/91 } \\
\text { (fig. 7) }\end{array}$ \\
\hline TW-1 & -- & -- & $1,542.34$ & $1,542.04$ \\
\hline TW-2 & -- & -- & $1,542.72$ & $1,542.45$ \\
\hline TW-3 & -- & -- & $1,538.16$ & $1,537.38$ \\
\hline TW-4 & -- & - & $1,542.93$ & - \\
\hline MW-1 & $1,542.11$ & $1,542.09$ & $1,541.82$ & $1,541.70$ \\
\hline MW-2 & $1,541.14$ & $1,541.37$ & $1,540.98$ & -- \\
\hline MW-3 & $1,541.76$ & $1,541.96$ & $1,541.62$ & $1,541.32$ \\
\hline MW-4 & $1,540.94$ & $1,541.15$ & $1,540.69$ & $1,540.38$ \\
\hline MW-5 & $1,539.10$ & $1,539.35$ & $1,538.75$ & $1,538.35$ \\
\hline MW-6 & $1,539.05$ & $1,539.25$ & $1,538.68$ & $1,538.29$ \\
\hline MW-7 & $1,538.41$ & $1,538.68$ & $1,538.05$ & $1,537.64$ \\
\hline MW-8 & $1,537.03$ & $1,537.33$ & $1,536.63$ & $1,536.24$ \\
\hline MW-9 & $1,536.78$ & $1,537.01$ & $1,536.40$ & $1,536.00$ \\
\hline MW-10 & -- & -- & $1,542.77$ & $1,542.47$ \\
\hline MW-11 & -- & - & $1,532.81$ & $1,532.29$ \\
\hline MW-12 & -- & - & $1,536.51$ & $1,536.10$ \\
\hline MW-13 & -- & -- & $1,534.72$ & $1,534.33$ \\
\hline MW-14 & - & -- & $1,528.81$ & $1,528.37$ \\
\hline OX-19 & -- & -- & $1,529.10$ & $1,528.66$ \\
\hline OX-20 & -- & -- & $1,528.85$ & $1,528.26$ \\
\hline OX-21 & -- & -- & $1,529.09$ & $1,528.62$ \\
\hline OX-22 & -- & - & $1,528.94$ & $1,528.37$ \\
\hline OX-26 & - & - & $1,528.28$ & $1,527.86$ \\
\hline OX-29 & -- & - & $1,529.83$ & $1,529.36$ \\
\hline OX-30 & -- & -- & $1,530.42$ & $1,529.92$ \\
\hline OX-31 & -- & - & $1,531.08$ & $1,530.60$ \\
\hline OX-32 & -- & - & $1,531.29$ & $1,530.83$ \\
\hline OX-33 & - & -- & $1,531.10$ & $1,530.65$ \\
\hline OX-35 & -- & -- & $1,530.91$ & $1,530.48$ \\
\hline OX-36 & - & - & $1,529.52$ & $1,529.17$ \\
\hline OX-37 & - & -- & $1,530.31$ & $1,530.02$ \\
\hline OX-38 & - & -- & $1,530.00$ & $1,529.68$ \\
\hline CR-3 & - & - & $1,542.23$ & $1,542.12$ \\
\hline
\end{tabular}

1 Data from Reno County files (Hutchinson). 
Table 7. Top-of-casing altitudes, total depths, and screened depths of temporary wells (TW), monitoring wells $(M W)$, industrial-storage wells $(S W)$, industrial-disposal wells $(D W)$, and industrial-observation wells (OX and EP) in vicinity of the Reno County Landfill

[ --, missing data; wells TW-1, TW-2, and TW-3, were drilled to 95 feet but were cased at more shallow depths]

\begin{tabular}{|c|c|c|c|}
\hline Well (fig. 5) & $\begin{array}{c}\text { Top-of-casing } \\
\text { altitude } \\
\text { (feet above sea } \\
\text { level) }\end{array}$ & $\begin{array}{l}\text { Total depth below } \\
\text { land surface (feet) }\end{array}$ & $\begin{array}{l}\text { Screened interval depth below land } \\
\text { surface (feet) }\end{array}$ \\
\hline TW-1 & $1,584.64$ & 90.5 & 85.5 to 90.5 \\
\hline TW-2 & $1,569.19$ & 50.2 & 45.2 to 50.2 \\
\hline TW-3 & $1,548.58$ & 34.0 & 29.0 to 34.0 \\
\hline $\mathrm{TW}-4$ & $1,568.08$ & 32.0 & 27.0 to 32.0 \\
\hline MW-1 & $1,555.18$ & 36.0 & 12.0 to 36.0 \\
\hline MW-2 & $1,572.23$ & 34.5 & 24.5 to 34.5 \\
\hline MW-3 & $1,598.12$ & 72.0 & 48.0 to 72.0 \\
\hline MW-4 & $1,596.79$ & 57.0 & 46.0 to 57.0 \\
\hline MW-5 & $1,566.89$ & 45.0 & 22.0 to 45.0 \\
\hline MW-6 & $1,563.43$ & 42.0 & 20.0 to 42.0 \\
\hline MW-7 & $1,560.62$ & 56.0 & 30.0 to 56.0 \\
\hline MW-8 & $1,551.79$ & 34.0 & 12.5 to 34.0 \\
\hline MW-9 & $1,559.67$ & 39.0 & 17.0 to 39.0 \\
\hline MW-10 & $1,566.86$ & 32.0 & 27.0 to 32.0 \\
\hline MW-11 & $1,545.56$ & 33.8 & 28.8 to 33.8 \\
\hline MW-12 & $1,558.23$ & 92.1 & 87.1 to 92.1 \\
\hline MW-13 & $1,576.03$ & 48.0 & 43.0 to 48.0 \\
\hline MW-14 & $1,549.04$ & 25.0 & 20.0 to 25.0 \\
\hline SW-70 & 1,549 & 860.0 & -- \\
\hline SW-71 & 1,549 & 860.0 & -- \\
\hline SW-72 & 1,549 & 860.0 & -- \\
\hline DW-2 & 1,555 & 4,735 & -. \\
\hline DW-3 & 1,557 & 4,751 & -- \\
\hline OX-19 & $1,549.70$ & 42.5 & -- \\
\hline OX-20 & $1,549.53$ & 104.0 & -- \\
\hline OX-21 & $1,550.65$ & 84.0 & -. \\
\hline OX-22 & $1,552.24$ & 122.0 & -- \\
\hline OX-26 & $1,536.11$ & 98.0 & 78.0 to 98.0 \\
\hline OX-29 & $1,549.08$ & 40.0 & 8.0 to 40.0 \\
\hline OX-30 & $1,549.54$ & 29.0 & -- \\
\hline OX-31 & $1,550.74$ & 34.0 & -- \\
\hline OX-32 & $1,552.40$ & 31.5 & -. \\
\hline OX-33 & $1,551.50$ & 37.0 & -- \\
\hline OX-35 & $1,551.54$ & 33.0 & -. \\
\hline OX-36 & $1,551.71$ & .. & -. \\
\hline OX-37 & $1,554.13$ & 40.0 & 8.0 to 40.0 \\
\hline OX-38 & $1,552.70$ & 40.0 & 10.0 to 40.0 \\
\hline EP-3 & - & 114.0 & $\begin{array}{l}30.0 \text { to } 65.0 \\
79.0 \text { to } 114.0\end{array}$ \\
\hline \multirow[t]{2}{*}{ EP-4 } & -- & 145.0 & 20.0 to 80.0 \\
\hline & & & 85.0 to 145.0 \\
\hline
\end{tabular}




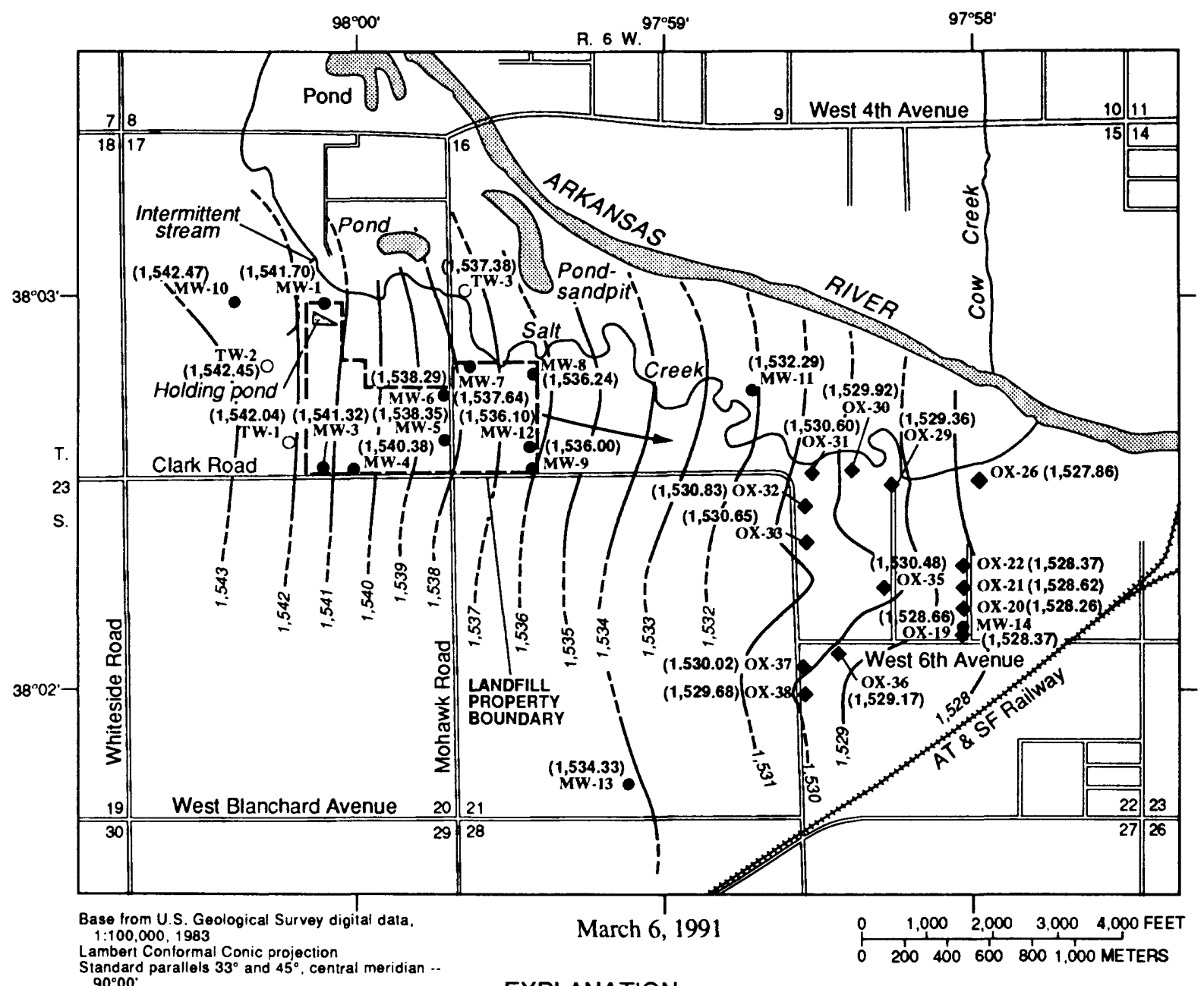

EXPLANATION
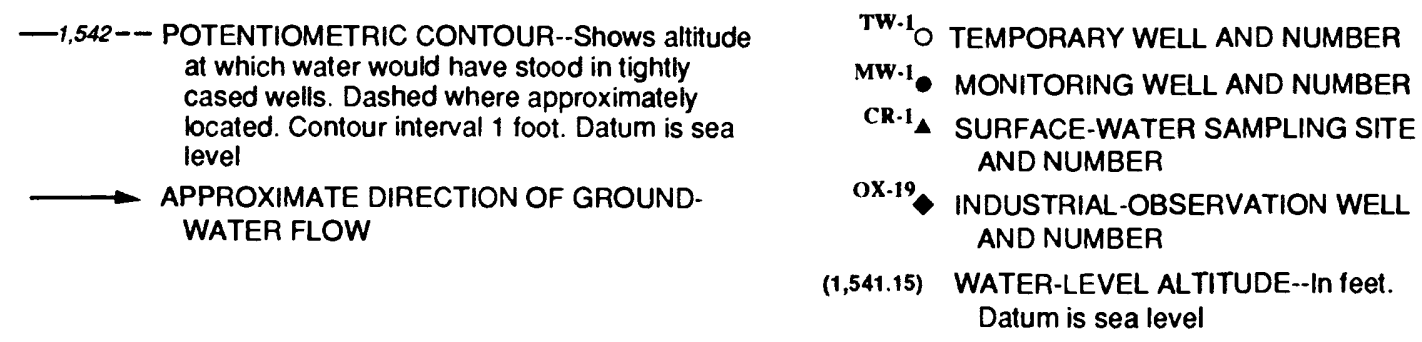

Figure 10. Potentiometric surface in Quaternary sediment, Reno County Landfill and vicinity, March 6, 1991 (water-level altitudes listed in table 6).

$$
\bar{v}=-\frac{K}{n}\left(\frac{d h}{d l}\right),
$$

where

$$
\begin{aligned}
\bar{v}= & \text { average linear velocity of ground } \\
& \text { water, in feet per day; }
\end{aligned}
$$

$K=$ hydraulic conductivity, in feet per day;

$\frac{d h}{d l}=\begin{aligned} & \text { hydraulic gradient, in feet per foot; } \\ & \text { and }\end{aligned}$

$\mathrm{n}=$ porosity, dimensionless. 

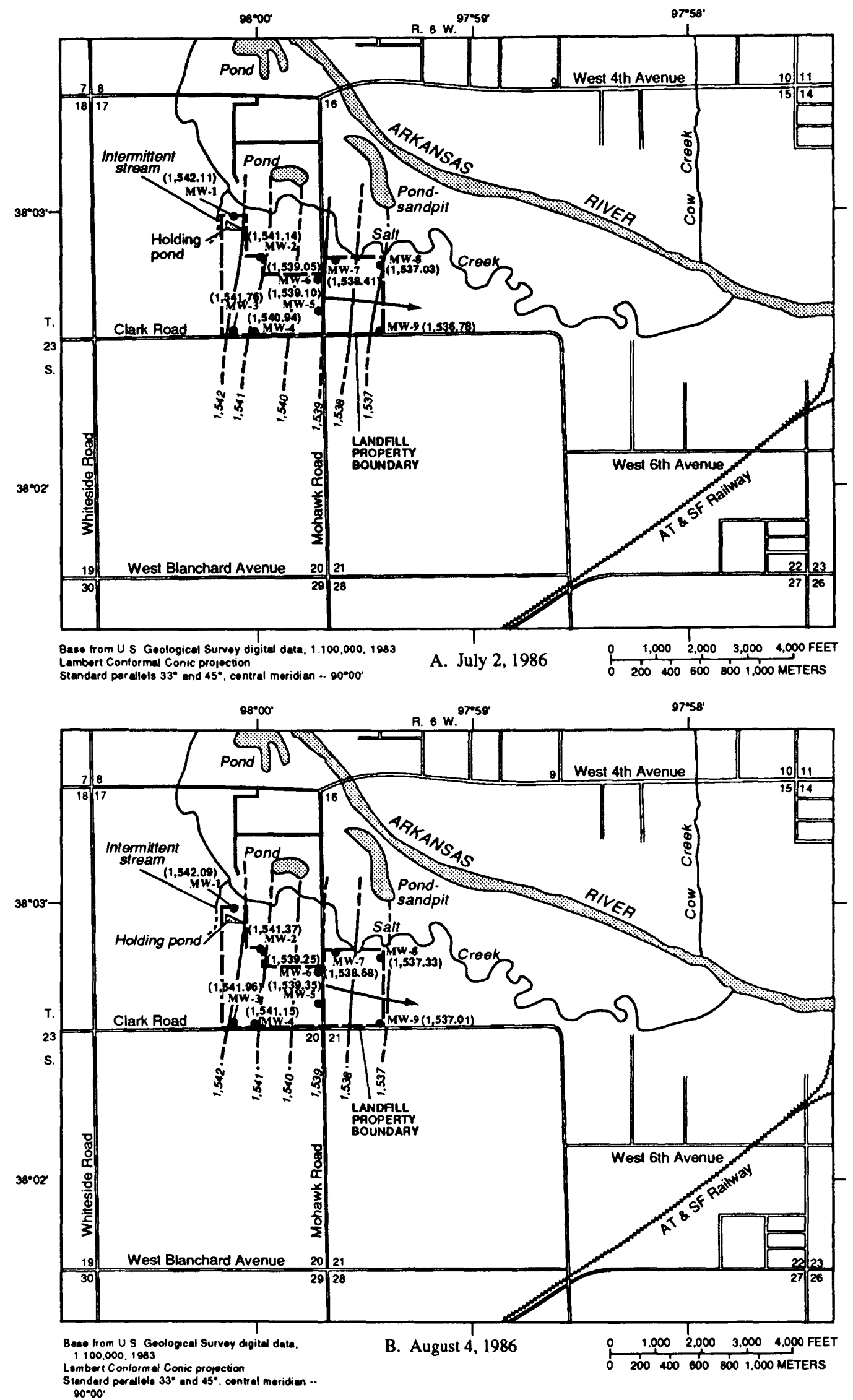

Figure 11. Potentiometric surface in Quaternary sediment, Reno County Landfill and vicinity, (A) July 2 and (B) August 4, 1986, and (C) August 22, 1990 (data for 1986 from Reno County files). 


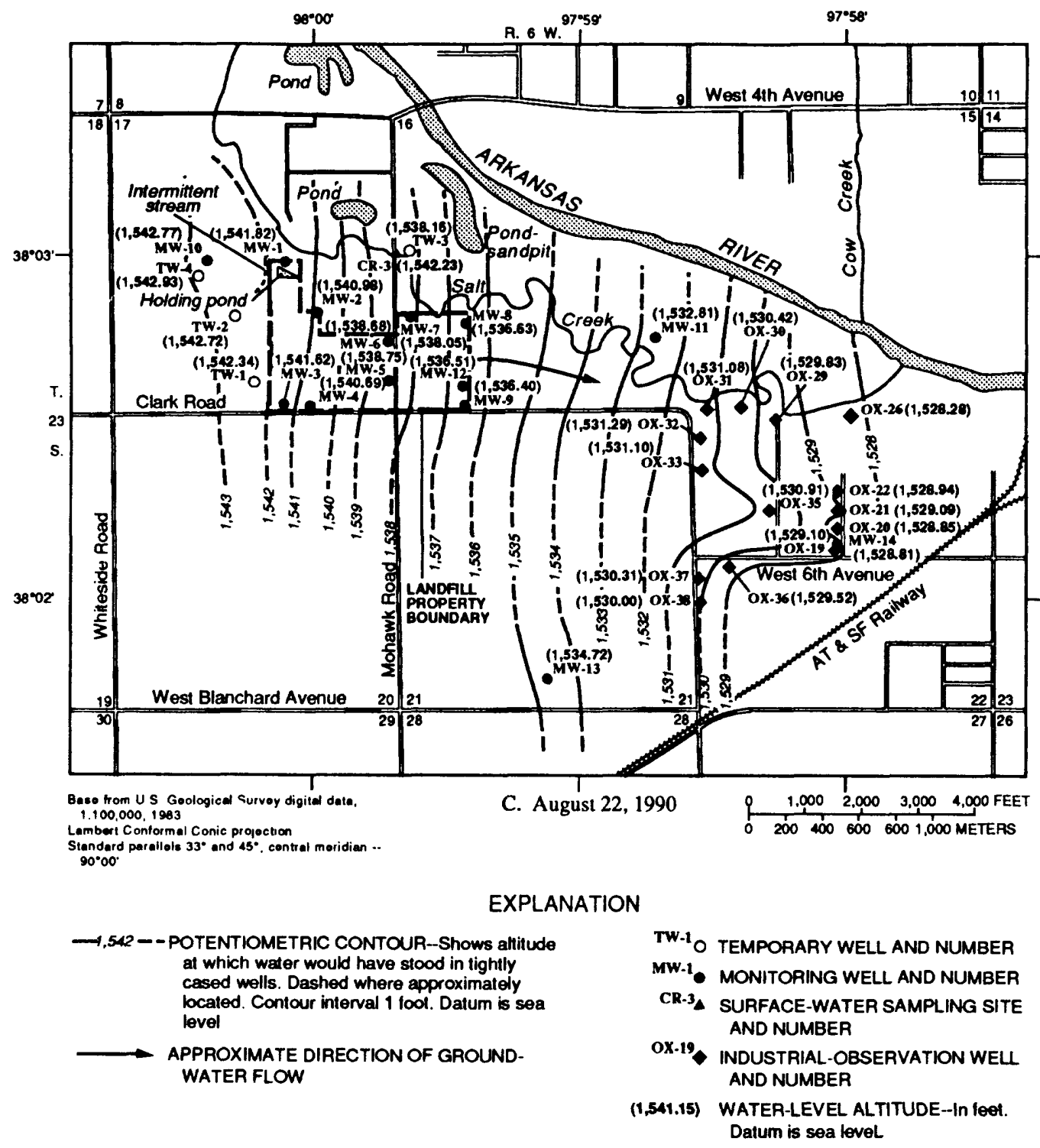

Figure 11. Potentiometric surface in Quaternary sediment, Reno County Landfill and vicinity, (A) July 2 and (B) August 4, 1986, and (C) August 22, 1990 (data for 1986 from Reno County files)--Continued

The Hvorslev (1951) method and Bouwer and Rice (1976) method yielded similar hydraulicconductivity values, with the Bouwer and Rice (1976) analysis producing a smaller value for hydraulic conductivity (table 8 ).

The average linear velocity of ground water can be calculated using the hydraulic gradient, the porosity, and the hydraulic conductivity. The hydraulic gradient can be determined from a potentiometric-contour map. The change in water level over the corresponding distance is the hydraulic gradient. From the potentiometric-contour map for March 6, 1991 (fig. 10), the change in water level is 7 feet over a distance of 1 mile; therefore, the hydraulic gradient is about 0.0013 for the landfill area
(7 feet $/ 5,280$ feet). The porosity for unconsolidated sand ranges from 20 to 35 percent (Fetter, 1988). Using equation 1, a porosity of 0.25 , a hydraulic gradient of 0.0013 , and a maximum hydraulic conductivity of 145 feet per day (table 8), the maximum average linear velocity of the water through the sand deposits is 0.75 foot per day. This is an average water velocity. Ground water and contaminants may move faster or slower depending on variations in hydraulic conductivity, porosity, and contaminant retardation factors.

\section{REGIONAL WATER QUALITY}

Ground-water supplies in Reno County primarily are obtained from unconsolidated 
Table 8. Hydraulic conductivity at the Reno County Landfill calculated from slug-test data

[All data are reported in feet per day]

\begin{tabular}{|c|c|c|}
\hline $\begin{array}{l}\text { Well number } \\
\text { (fig. 5) }\end{array}$ & $\begin{array}{c}\text { Hvorslev } \\
\text { (1951) method }\end{array}$ & $\begin{array}{l}\text { Bouwer and } \\
\text { Rice (1976) } \\
\text { method } \\
\text { (numeric } \\
\text { algorithm) }\end{array}$ \\
\hline TW-2 & 85 & $\overline{65}$ \\
\hline TW-3 & 35 & 30 \\
\hline MW-10 & 145 & 120 \\
\hline MW-12 & 50 & 45 \\
\hline
\end{tabular}

sand-and-gravel deposits. Water from the terrace deposits is considered suitable for most uses but generally is hard. The quality of water from the alluvium and most surface water in Reno County, particularly in the Arkansas River, is unsuitable for most uses because of large chloride and dissolved-solids concentrations (Bayne, 1956).

\section{LANDFILL-AREA WATER QUALITY}

State and Federal drinking-water regulations for public supplies have been established for some chemical constituents that can produce adverse health effects or that affect the aesthetic qualities of water, such as taste, smell, and appearance. Tables 9, 10, and 11 list physical properties, inorganic constituents, organic constituents, tentatively identified organic constituents, and concentrations of constituents reported in analyses of water samples from monitoring wells, private-supply wells, and Salt Creek. These tables include applicable drinking-water regulations for these constituents.

The Kansas Notification Level (KNL) (table 10 ) is the concentration of a constituent in water at which there would be no adverse health effects for lifetime consumption, or, for carcinogens, which would increase the risk of cancer by no more than one in $1,000,000$ (Kansas Department of Health and Environment, 1986). The Kansas Action Level (KAL) (table 10) is the concentration above which a constituent could produce adverse health effects after long-term consumption of the water (Kansas Department of Health and
Environment, 1986). The Maximum Contaminant Level Goal (MCLG) (table 10) is the concentration of a constituent in drinking water at which there would be no adverse health effects for lifetime consumption of the water (U.S. Environmental Protection Agency, 1990a). The Maximum Contaminant Level (MCL) (tables 9 and 10) is the maximum permissible level of a contaminant in water that may be delivered to a free-flowing outlet of a public-water system. The MCL is based on the capacity of the best-available technology to minimize contaminant concentrations in drinking water (U.S 'nvironmental Protection Agency, $1990 \mathrm{~b}$ and c). Secondary Maximum Contaminant Levels (SMCL) (table 9) have been established for constituents that affect the aesthetic qualities of the water (U.S. Environmental Agency, 1990d).

Water samples were collected by the U.S. Geological Survey in August 1990 from eight monitoring wells, five private-supply wells, and two sampling sites along Salt Creek. The monitoring wells sampled included five installed by the U.S. Geological Survey (wells MW-10, MW-11, MW-12, MW-13, and MW-14) and three existing monitoring wells (wells MW-5, MW-8, MW-9). The private-supply wells sampled were wells PW-1, PW-2, PW-3, PW-4, $P W-5$. A duplicate sample was collected from a randomly chosen well (well MW-9dup) for quality control. The sample from well MW-10 (upgradient of the landfill) was used to compare the quality of water that enters the landfill to water from downgradient wells. The water-quality analyses from these samples are presented in tables 9,10 , and 11 .

Two water types are present in the vicinity of the landfill as shown in figure 12 . Figure 12 indicates major-ion concentrations in milliequivalents per liter plotted on modified Stiff (1951) diagrams. Sodium bicarbonate type water was found in samples from wells MW-9, MW-13, PW-1, PW-3, PW-4, and PW-5, and sodium chloride type water was found in samples from wells MW-5, MW-8, MW-10, MW-11, MW-12, MW-14, and PW-2 and surface-water sampling sites CR-1 and CR-2. 


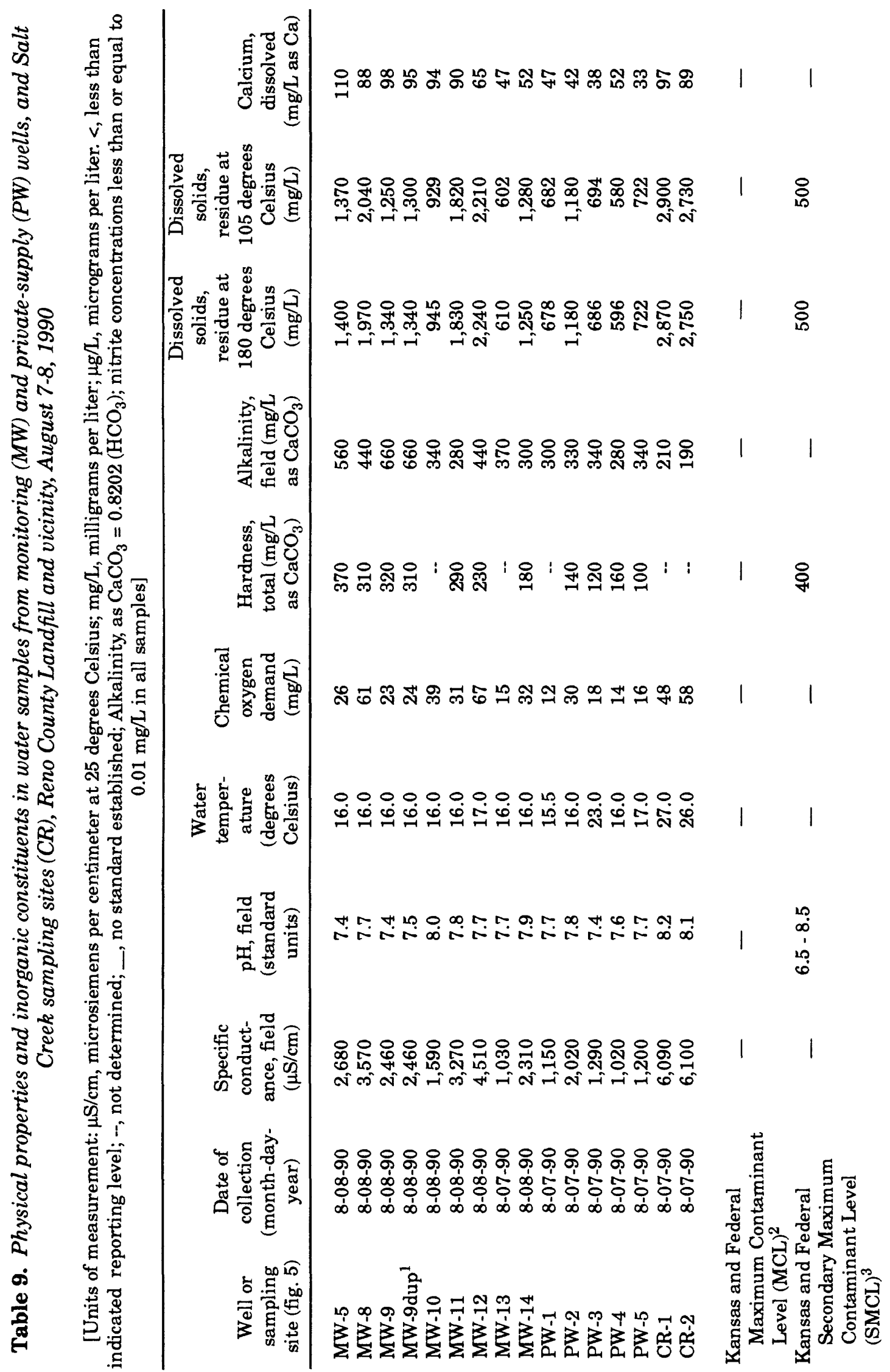




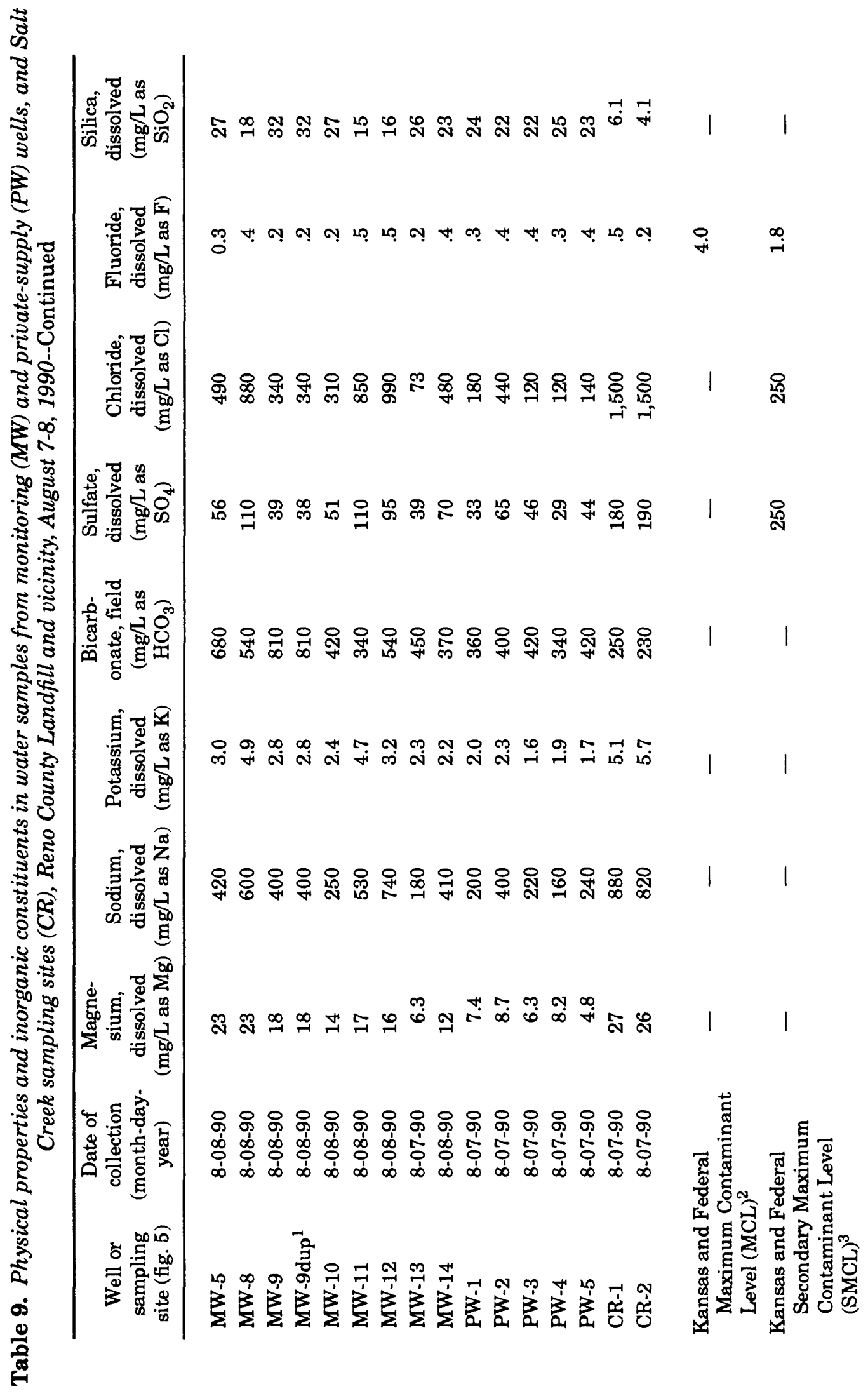




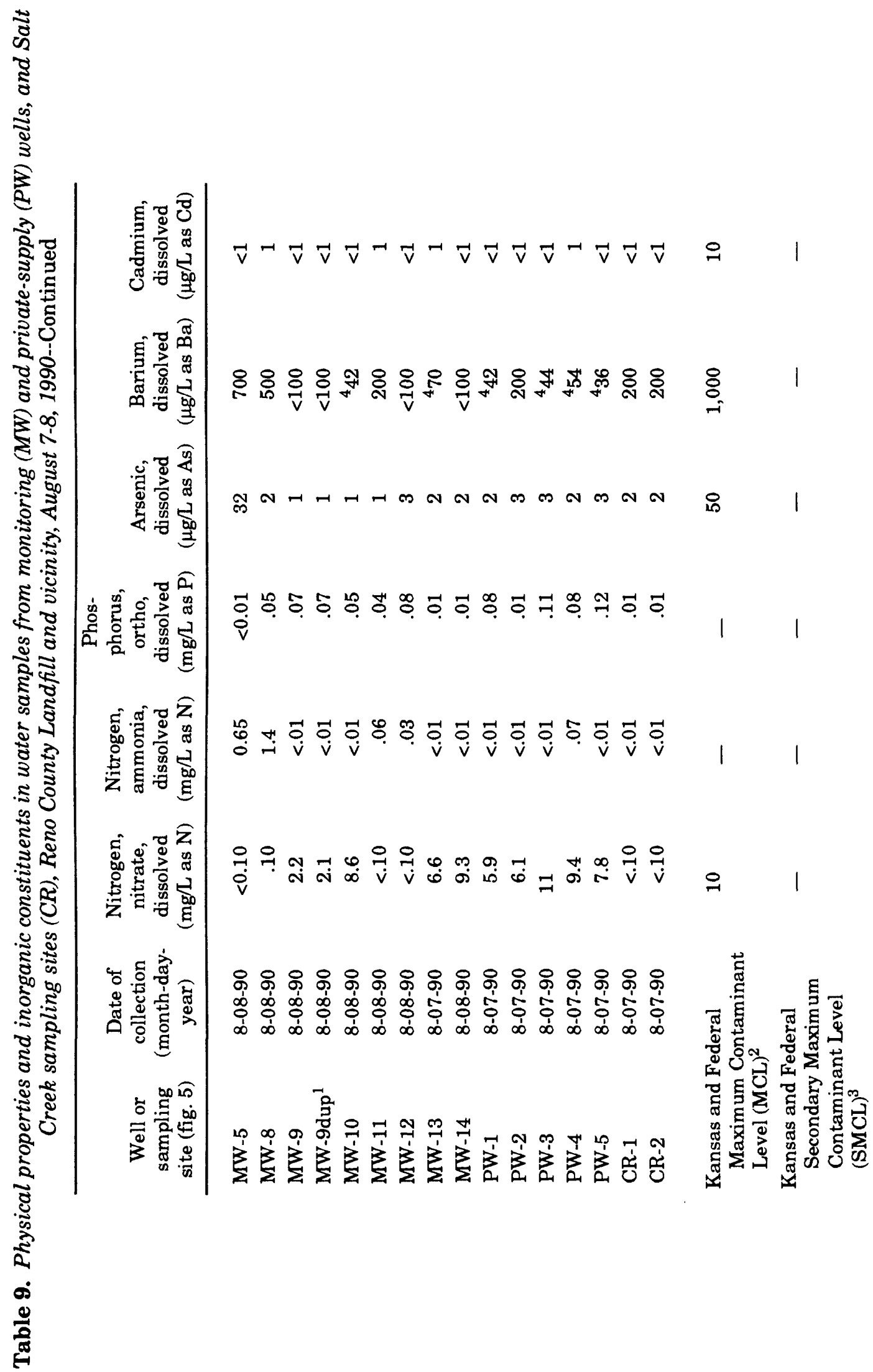




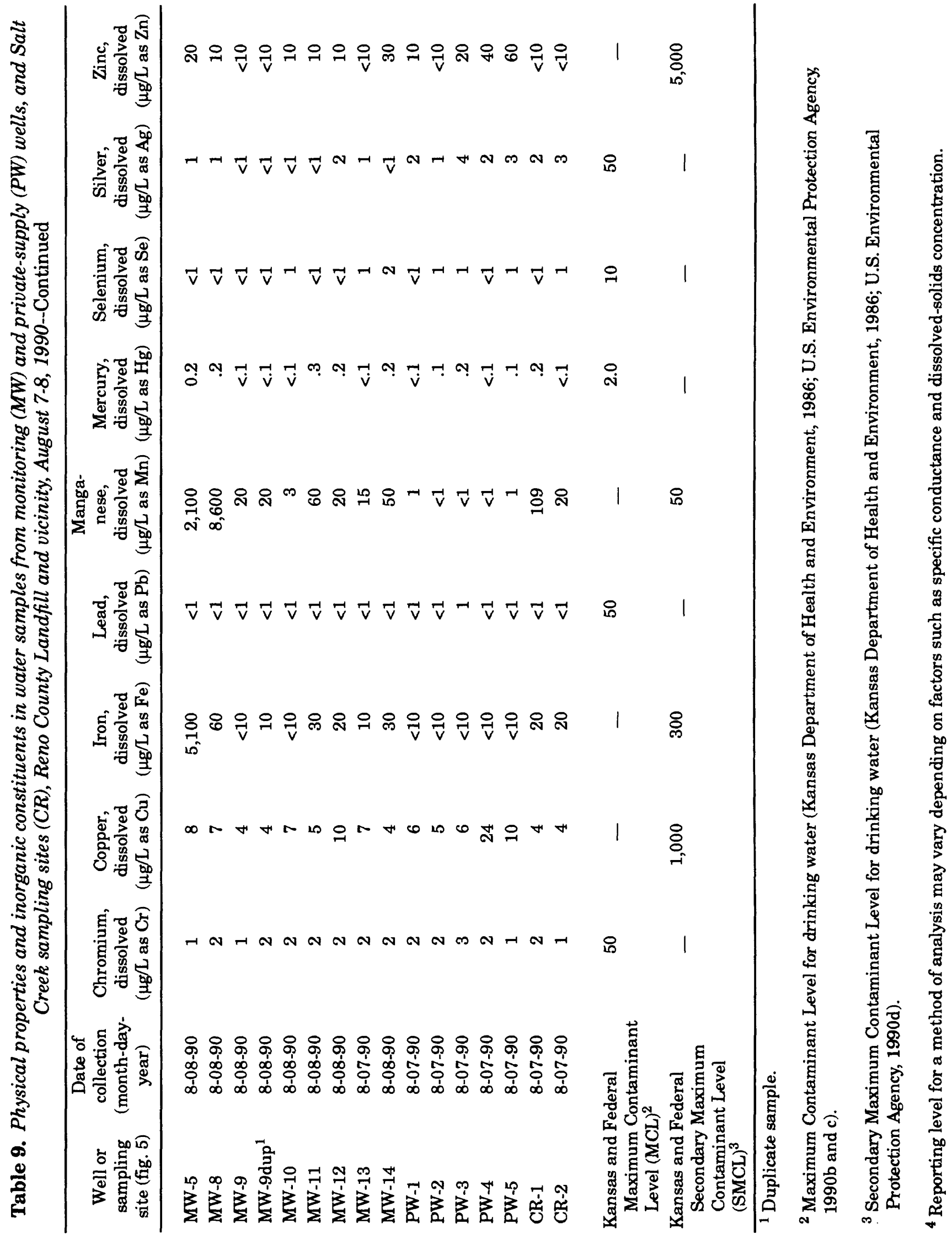




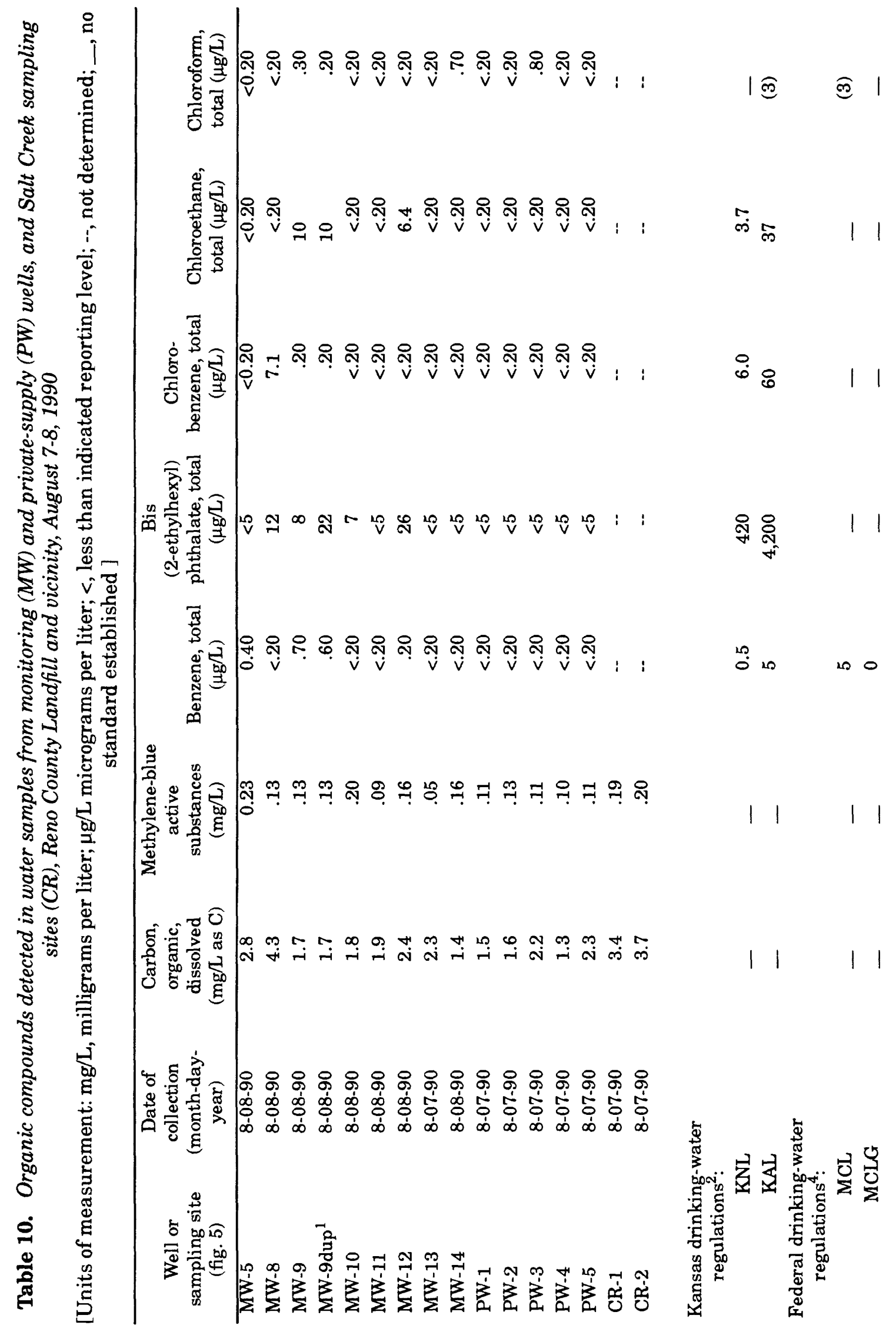




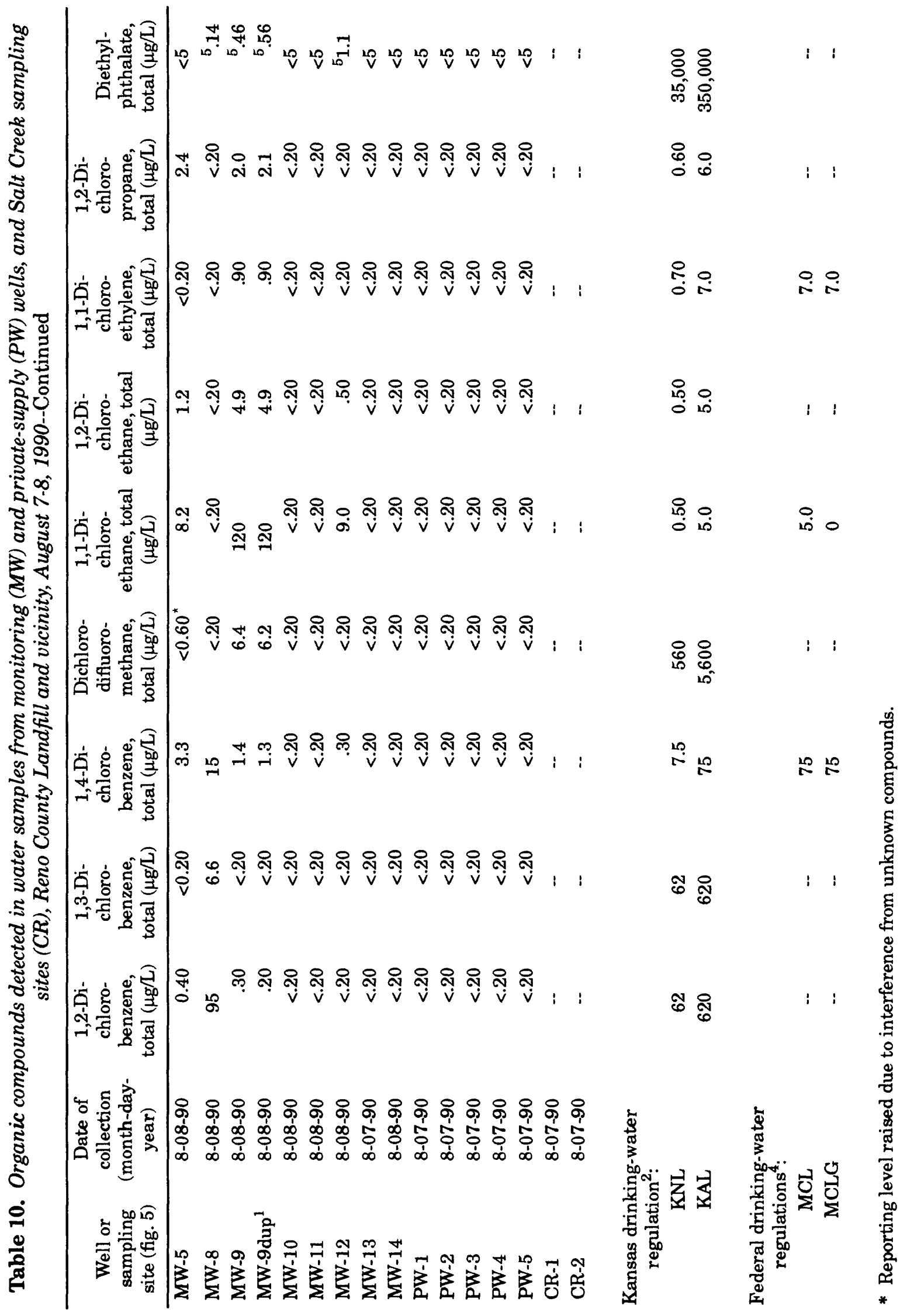




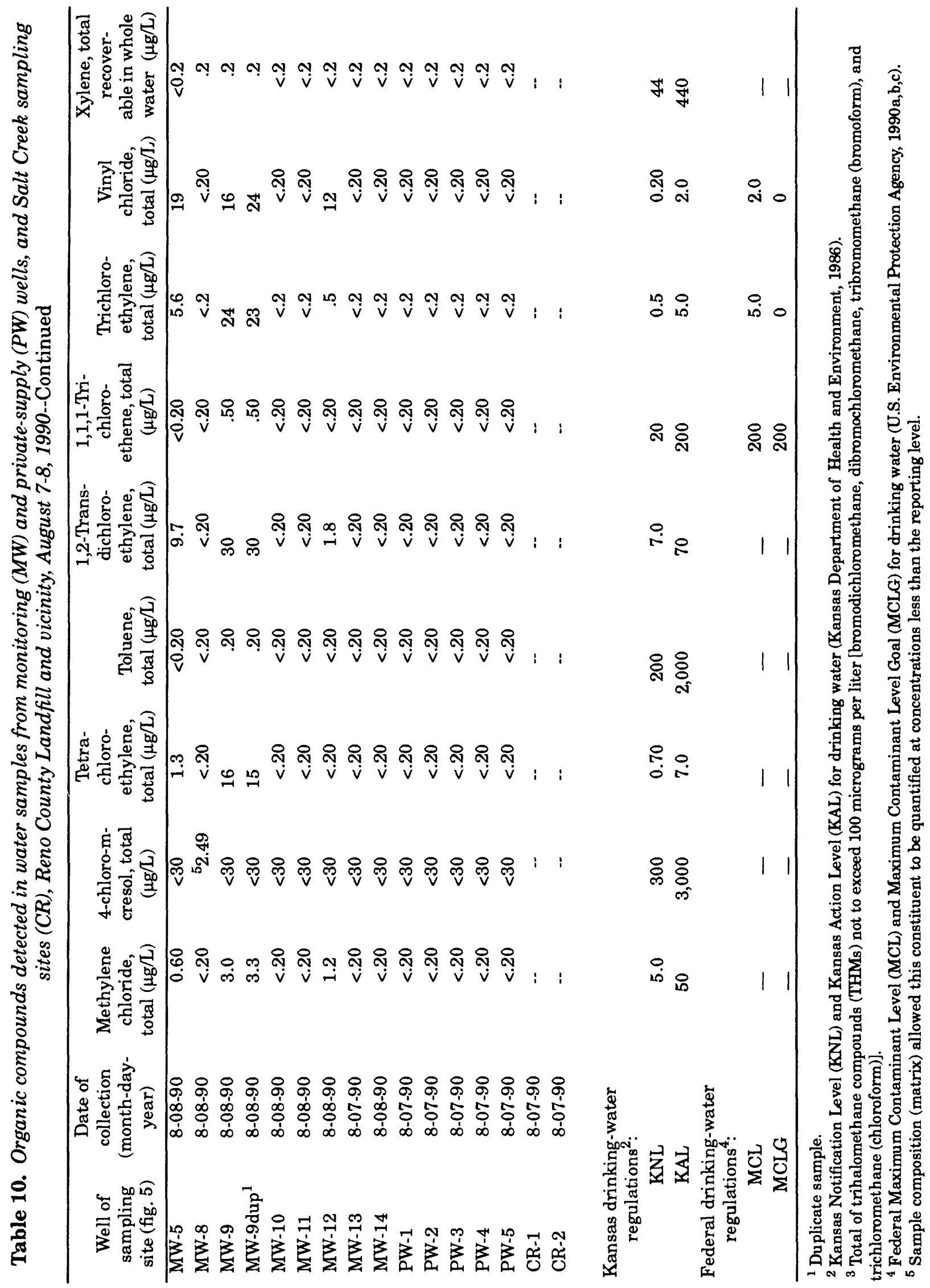


Table 11. Organic compounds detected in water samples collected August 7-8, 1990, in the vicinity of Reno County Landfill. Compounds tentatively identified by computerized library search

\begin{tabular}{|c|c|c|}
\hline Well (fig. 5) & Compounds & \\
\hline MW-5 & $\begin{array}{l}\text { Benzene, (phenoxymethyl) } \\
\text { Benzothiazole } \\
\text { 2(3H)-benzothiazolone } \\
\text { Dichlorofluoromethane } \\
\text { Diethyl ether } \\
\text { Dodecanoic acid }\end{array}$ & $\begin{array}{l}\text { 2-(2-ethoxyethoxy)- } \\
\quad \text { ethanol (Carbitol }{ }^{1} \text { ) } \\
\text { Hexadecanoic acid } \\
\text { Methylbenzene } \\
\text { Neophytadiene }\end{array}$ \\
\hline MW-8 & $\begin{array}{l}\text { 2(3H)-benzothiazolone } \\
\text { 2-cyanocarbazole and RBr2 } \\
\text { Chlorobenzene } \\
\text { Diethyl ether } \\
\text { 2,4-dimethyl phenol } \\
\text { Dodecanoic acid }\end{array}$ & $\begin{array}{l}\text { Hexadecanoic acid } \\
\text { N-(1,1-dimethylethyl)-3- } \\
\quad \text { methylbenzamide (Deet) } \\
\text { N-(4-hydroxyphenyl)-acetamide } \\
\text { Phosphoric acid }\end{array}$ \\
\hline MW-9 & $\begin{array}{l}\text { Chlorobenzene } \\
\text { Chlorofluoromethane } \\
\text { Diethyl ether } \\
\text { 1,4-dimethyl-benzene } \\
\text { Dodecanoic acid } \\
\text { 1-ethyl-3,5-dimethylbenzene } \\
\text { 2-(2-ethoxyethoxy)- } \\
\text { ethanol (Carbitol }^{1} \text { ) }\end{array}$ & $\begin{array}{l}\text { Hexadecanoic acid } \\
\text { 2-methyl-benzenesulfonamide } \\
\text { N-(1,1-dimethylethyl)-3- } \\
\text { methylbenzamide (Deet) } \\
\text { N-ethyl-4-methyl-benzene- } \\
\text { sulfonamide } \\
\text { N-ethyl toluene sulfonamide } \\
\text { Tetrachloroethene }\end{array}$ \\
\hline MW-9dup ${ }^{2}$ & $\begin{array}{l}\text { Chlorobenzene } \\
\text { Chlorofluoromethane } \\
\text { Dichlorofluoromethane } \\
\text { 4-chloro-trans-cyclohexanol } \\
\text { Diethyl ether } \\
\text { 1,3-dimethyl-benzene }\end{array}$ & $\begin{array}{l}\text { 2-ethyl-1,4-dimethyl-benzene } \\
\text { Hexadecanoic acid } \\
\text { 2-methyl-benzenesulfonamide } \\
\text { N-ethyl-4-methyl-benzene- } \\
\text { sulfonamide } \\
\text { Octadecanoic acid } \\
\text { Tetrachloroethene }\end{array}$ \\
\hline MW-12 & $\begin{array}{l}\text { Benzoic acid } \\
\text { 2-butoxyethanol } \\
\text { Dichlorofluoromethane } \\
\text { Diethyl ether } \\
\text { Dodecanoic acid } \\
\text { 2-(2-ethoxyethoxy)- } \\
\text { ethanol (Carbitol }^{1} \text { ) } \\
\text { Hexadecanoic acid } \\
\text { 2-methyl-azetidine } \\
\text { 2-methyl-benzenesulfonamide } \\
\text { 2-methyl-phenanthrene }\end{array}$ & $\begin{array}{l}\text { N-ethyl-4-methyl-benzene } \\
\text { sulfonamide } \\
\text { N,N,4-trimethyl-benzene- } \\
\text { sulfonamide } \\
\text { Pentacosane } \\
\text { Tetrachloroethene } \\
\text { Phosphoric acid } \\
\text { Toluenesulfonamide and } \\
\text { benzothiazolone } \\
\text { Tricosane }\end{array}$ \\
\hline PW-2 & $\begin{array}{l}\left.\text { 2-(2-ethoxyethoxy)-ethanol (Carbitol }{ }^{1}\right) \\
\text { Tetrachloroethene }\end{array}$ & \\
\hline PW-3 & $\begin{array}{l}\text { 1,6-dimethyl-4-isopropylnapthalene (Cadalene) } \\
\text { Hydroxyalkybenzene }\end{array}$ & \\
\hline PW-4 & $\begin{array}{l}\text { 1,4-dimethyl-benzene } \\
\text { 2-(2-ethoxyethoxy)-ethanol (Carbitol }{ }^{1} \text { ) }\end{array}$ & \\
\hline
\end{tabular}

${ }^{1}$ Use of the trade names in this report is for identification purposes only and does not constitute endorsement by the U.S. Geological Survey.

2 Duplicate sample. 


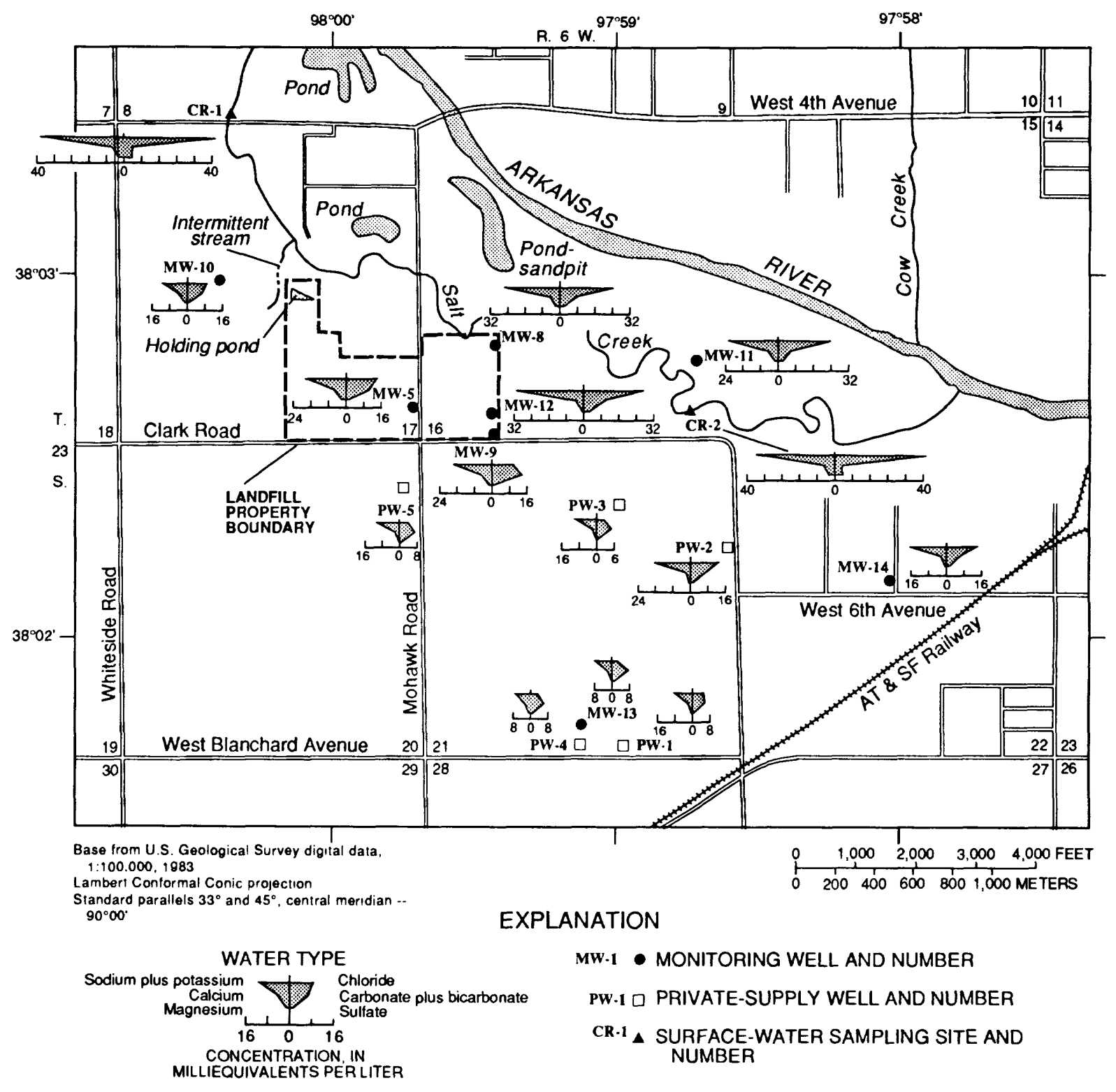

Figure 12. Modified Stiff diagrams of major-ion concentrations in water samples collected from monitoring and private-supply wells and surface-water sites, Reno County Landfill and vicinity, August 7-8, 1990.

\section{Physical and Chemical Properties}

Physical and chemical properties determined were specific conductance, $\mathrm{pH}$, temperature, chemical oxygen demand, total hardness (as $\mathrm{CaCO}_{3}$ ), and alkalinity. Specific conductance, $\mathrm{pH}$, temperature, and alkalinity were determined onsite.

Specific conductance is the ability of water to conduct an electrical current (Freeze and Cherry, 1979). It also is an indirect measure of the concentration of dissolved solids in water; an increase in dissolved-solids concentration gives a proportional increase in specific conductance. Organic compounds in water also may increase the specific conductance. For wells in the study area, specific conductance was measured at the time of sample collection and ranged from $1,020 \mu \mathrm{S} / \mathrm{cm}$ (microsiemens per centimeter at 25 degrees Celsius) (private-supply well $\mathrm{PW}-4$ ) to $6,100 \mu \mathrm{S} / \mathrm{cm}$ (sampling site CR-2) (table 9). Specific conductance was larger than $2,500 \mu \mathrm{S} / \mathrm{cm}$ in water samples from Salt Creek 
and monitoring wells MW-5, MW-8, MW-11, and MW-12.

The $\mathrm{pH}$, a measure of the hydrogen activity, ranged from 7.4 (wells MW-5, MW-9, PW-3) to 8.2 (sampling site $\mathrm{CR}-1$ ). The $\mathrm{pH}$ values were uniform with no significant differences between well and creek samples. All $\mathrm{pH}$ values were within the range for the Kansas and Federal SMCL (table 9).

Water temperatures for Salt Creek were $26.0^{\circ} \mathrm{C}$ at sampling site $\mathrm{CR}-2$ and $27.0^{\circ} \mathrm{C}$ at sampling site CR-1 (table 9). The temperature of ground water in the study area ranged from 15.5 to $17.0{ }^{\circ} \mathrm{C}$ for all samples except from private-supply well $\mathrm{PW}-3\left(23.0^{\circ} \mathrm{C}\right)$. The high water temperature in well PW-3 may be due to the great distance the water has to travel from the well head to the sampling point (fig. 5).

Chemical oxygen demand (COD), a measure of the oxidizable material load in water, ranged from $12 \mathrm{mg} / \mathrm{L}$ (milligrams per liter) (private-supply well $\mathrm{PW}-1$ ) to $67 \mathrm{mg} / \mathrm{L}$ (well MW-12). Total hardness (expressed as $\mathrm{CaCO}_{3}$ ) ranged from 100 (private-supply well $\mathrm{PW}-5$ ) to $370 \mathrm{mg} / \mathrm{L}$ (monitoring well MW-5). Hardness is a measure of the concentration of calcium and magnesium carbonate, bicarbonate, sulfate, or chloride in water. Water with a hardness of more than $180 \mathrm{mg} / \mathrm{L}$ (as $\mathrm{CaCO}_{3}$ ) is classified as "very hard" (Hem, 1985, p. 159). Alkalinity concentrations, expressed as $\mathrm{CaCO}_{3}$, ranged from 190 (sampling site CR-2) to $660 \mathrm{mg} / \mathrm{L}$ (well MW-9). Alkalinity is defined as the capacity of solutes in water to neutralize acid.

\section{Dissolved Solids and Major Ions}

Dissolved solids, measured by the amount of residue after evaporation of a water sample at $105{ }^{\circ} \mathrm{C}$ and $180{ }^{\circ} \mathrm{C}$, ranged from 580 (private-supply well $\mathrm{PW}-4$ ) to $2,900 \mathrm{mg} / \mathrm{L}$ (sampling site CR-1) at $105^{\circ} \mathrm{C}$. All the samples analyzed exceeded the SMCL of $500 \mathrm{mg} / \mathrm{L}$ for dissolved solids (table 9). The water samples from wells collected farthest from the landfill tended to have smaller values of dissolved solids, especially samples from wells southeast of the landfill (private-supply wells PW-1 and PW-4, monitoring well MW-13). Dissolved solids are mainly mineral constituents but may include small quantities of organic matter. More than $1,000 \mathrm{mg} / \mathrm{L}$ dissolved solids can cause noticeable taste or otherwise make the water undesirable or unsuitable for use (Bayne, 1956).

Water samples were analyzed for dissolved major cations including calcium, magnesium, sodium, and potassium, and for dissolved major anions including bicarbonate (computed from alkalinity), sulfate, chloride, fluoride, and silica. The two surface-water sampling sites (sampling sites CR-1 and CR-2) had some of the largest concentrations of the major ions, especially chloride (table 9). Ground water south and southeast of the landfill (wells PW-1, PW-2, PW-3, PW-4, PW-5, MW-13) tended to have smaller concentrations of the major ions than elsewhere. Calcium concentrations ranged from 33 (private-supply well $\mathrm{PW}-5$ ) to $110 \mathrm{mg} / \mathrm{L}$ (well MW-5). Magnesium concentrations ranged from 4.8 (private-supply well $\mathrm{PW}-5$ ) to $27 \mathrm{mg} / \mathrm{L}$ (sampling site CR-1). Sodium concentrations ranged from 160 (private-supply well PW-4) to $880 \mathrm{mg} / \mathrm{L}$ (sampling site CR-1). Potassium concentrations ranged from 1.6 (private-supply well PW-3) to $5.7 \mathrm{mg} / \mathrm{L}$ (sampling site CR-2) (table 9).

Bicarbonate concentrations (table 9) ranged from $230 \mathrm{mg} / \mathrm{L}$ (sampling site CR-2) to $810 \mathrm{mg} / \mathrm{L}$ (well MW-9). Bicarbonate concentrations were largest in samples from beneath the landfill property (wells MW-5, MW-8, MW-9, MW-12). Sulfate concentrations ranged from $29 \mathrm{mg} / \mathrm{L}$ in water from private-supply well PW-4 to $190 \mathrm{mg} / \mathrm{L}$ at sampling site CR-2 and did not exceed the Kansas or Federal SMCL of $250 \mathrm{mg} / \mathrm{L}$ in any samples. Chloride concentrations in water from sampled wells ranged from 73 (well MW-13) to $990 \mathrm{mg} / \mathrm{L}$ (well $\mathrm{MW}-12$ ). Chloride concentrations in water from wells MW-13, PW-1, PW-3, PW-4, and PW-5 were less than the Kansas and Federal SMCL of $250 \mathrm{mg} / \mathrm{L}$. Both creek samples had large concentrations of chloride $(1,500 \mathrm{mg} / \mathrm{L})$. Generally, the water samples from wells south and southeast of the landfill had the smallest concentrations of chloride as shown in figure 12 .

\section{Nutrients}

Water samples were analyzed for dissolved concentrations of nutrients, including nitrite, nitrite plus nitrate, ammonia, and orthophosphorus. Nitrite concentrations expressed 
as milligrams per liter as nitrogen were less than or equal to $0.01 \mathrm{mg} / \mathrm{L}$ in all samples. Nitrate concentrations are expressed as milligrams per liter as nitrogen in this report. Nitrate was detected in all the private-supply wells sampled, with well PW-3 exceeding the State and Federal MCL of $10 \mathrm{mg} / \mathrm{L}$ for nitrate as nitrogen (table 9). The sample from the upgradient well (well MW-10) had a nitrate-as-nitrogen concentration of $8.6 \mathrm{mg} / \mathrm{L}$, indicating that nitrate in ground water may have a natural source or come from sources other than the landfill. Ammonia concentrations are expressed as milligrams per liter of nitrogen in this report. Ammonia concentrations ranged from less than $0.01 \mathrm{mg} / \mathrm{L}$ in most samples to $1.4 \mathrm{mg} / \mathrm{L}$ in a water sample from well $\mathrm{MW}-8$ (table 9). Orthophosphorus concentrations, reported in milligrams per liter as phosphorus, ranged from less than $0.01 \mathrm{mg} / \mathrm{L}$ in a water sample from well MW-5 to $0.12 \mathrm{mg} / \mathrm{L}$ in a water sample from well PW-5.

The presence of nitrate or ammonia in water can be used as an indicator of whether oxidizing or reducing conditions prevail. In the presence of reducing conditions, typical of landfill leachate, nitrate may be reduced to ammonia. This effect was observed at the Geary County, Kansas, landfill (Myers and Bigsby, 1989). At the Reno County Landfill, nitrate occurs in water from the upgradient well (well MW-10) and downgradient wells, except that nitrate concentrations were less than $0.10 \mathrm{mg} / \mathrm{L}$ in water samples from wells MW-5, MW-11, and MW-12. The largest ammonia concentrations were in water samples from wells MW-5 and MW-8 that were located on the landfill and may indicate that reducing conditions are present.

\section{Trace Elements}

Dissolved trace elements analyzed in water samples were arsenic, barium, cadmium, chromium, copper, iron, lead, manganese, mercury, selenium, silver, and zinc. All trace-element concentrations were measured in micrograms per liter $(\mu \mathrm{g} / \mathrm{L})$. Arsenic, barium, iron, and manganese concentrations in some water samples approached or exceeded the State and Federal MCL and SMCL. The arsenic concentration was $32 \mu \mathrm{g} / \mathrm{L}$ in a water sample from well MW-5 but did not exceed the State or Federal MCL of $50 \mu \mathrm{g} / \mathrm{L}$. Barium concentrations in water samples ranged from less than $100 \mu \mathrm{g} / \mathrm{L}$ in wells MW-9, MW-12, and MW-14 to $700 \mu \mathrm{g} / \mathrm{L}$ in well MW-5. The State and Federal MCL for barium is $1,000 \mu \mathrm{g} / \mathrm{L}$ (table 9 ).

Iron and manganese concentrations in a water sample from well MW-5 were 5,100 and $2,100 \mu \mathrm{g} / \mathrm{L}$. These concentrations exceeded the Federal SMCL of $300 \mu \mathrm{g} / \mathrm{L}$ for iron and $50 \mu \mathrm{g} / \mathrm{L}$ for manganese. The manganese concentrations in water samples from wells MW-8, MW-11, MW-14, and surface-water sampling site CR-1 also equalled or exceeded the Federal SMCL (table 9).

\section{Other Inorganic Constituents}

Dissolved fluoride concentrations were $0.5 \mathrm{mg} / \mathrm{L}$ or less in all water samples analyzed (table 9). Dissolved silica concentrations ranged from $4.1 \mathrm{mg} / \mathrm{L}$ in a water sample from sampling site CR-2 to $32 \mathrm{mg} / \mathrm{L}$ in a water sample from well MW-9. Larger concentrations of silica were detected in the ground-water samples as compared to the two surface-water samples and probably are due to prolonged exposure of ground water to the aquifer material, dissolving the silica.

\section{Organic Compounds}

Water samples from the landfill-monitoring wells and private-supply wells were analyzed for organic compounds (table 12). Of the organic compounds listed in table 12,23 were detected in water samples (table 10), and 36 other non-target compounds were tentatively identified by a computerized library search (table 11). A non-target compound is a compound that was not specifically analyzed for using the gas chromatograph/mass spectrometer. The computerized library search uses the spectra of a non-target compound, at the gas chromatography peak maxima, and compares the spectra to National Bureau of Standards library reference spectra. The best library match is inspected manually to provide the best possible identification, but the non-target compound identification is still considered to be tentative (Brooke Connor, U.S. Geological Survey, written commun., 1990). No organic compounds other than dissolved organic carbon and methylene-blue active substances were detected in water samples collected from wells 
Table 12. Organic compounds analyzed in water samples collected from the Reno County Landfill and vicinity

\begin{tabular}{cc}
\hline Compound & $\begin{array}{c}\text { Reporting level, } \\
\text { in micrograms per liter }\end{array}$ \\
\hline
\end{tabular}

\section{Volatile Organic Compounds}

benzene

bromoform

carbon tetrachloride

chlorobenzene

chloroethane

2-chloroethyl vinyl ether

chloroform

chloromethane

dibromochloromethane

1,2-dibromoethane

dichlorobromomethane

1,2-dichlorobenzene

1,3-dichlorobenzene

1,4-dichlorobenzene

dichlorodifluoromethane

1,1-dichloroethane

1,2-dichloroethane

1,1-dichloroethylene

1,2-trans-dichloroethylene

1,2-dichloropropane

cis-1,3-dichloropropene

trans-1,3-dichloropropene

1,3-dichloropropene

ethylbenzene

methyl bromide

methylene chloride

styrene

1,1,2,2-tetrachloroethane

tetrachloroethylene

toluene

1,1,1-trichloroethane 
Table 12. Organic compounds analyzed in water samples collected from the Reno County Landfill and vicinity--Continued

\begin{tabular}{cc}
\hline Compound & $\begin{array}{c}\text { Reporting level, } \\
\text { in micrograms per liter }\end{array}$ \\
\hline
\end{tabular}

Volatile Organic Compounds--Continued

trichloroethylene

trichlorofluoromethane

vinyl chloride

xylenes, mixed

Semivolatile, Acid Extractable, Compounds

2-chlorophenol 5.0

2,4-dichlorophenol 5.0

2,4-dimethylphenol 5.0

4,6-dinitro-2-methylphenol

30

2,4-dinitrophenol

20

2-nitrophenol

5.0

4-nitrophenol

30

pentachlorophenol

30

phenol

2,4,6-trichlorophenol

20

4-chloro-m-cresol

30

\section{Semivolatile, Base-Neutral Extractable, Compounds}

acenaphthene

acenaphthylene

anthracene

benzo (a) anthracene 10

benzo (a) pyrene

benzo (b) fluoranthene 10

benzo $(k)$ fluoranthene 10

benzo $(\mathrm{g}, \mathrm{h}, \mathrm{i})$ perylene 10

4-bromophenyl phenyl ether 5.0

butyl benzyl phthalate

bis (2-chloroethoxy) methane

bis (2-chloroethyl) ether

bis (2-chloroisopropyl) ether

bis (2-ethylhexyl) phthalate

2-chloronaphthalene 
Table 12. Organic compounds analyzed in water samples collected from the Reno County Landfill and vicinity--Continued

Semivolatile, Base-Neutral Extractable, Compounds--Continued

4-chlorophenyl phenyl ether 5.0

chrysene 10

dibenzo $(\mathrm{a}, \mathrm{h})$ anthracene

10

1,2-dichlorobenzene

1,3-dichlorobenzene

1,4-dichlorobenzene

diethyl phthalate

5.0

dimethyl phthalate

5.0

di-n-butyl phthalate

5.0

2,4-dinitrotoluene

2,6-dinitrotoluene

5.0

di-n-octylphthalate

10

fluoranthene

fluorene

5.0

hexachlorobenzene

hexachlorobutadiene

hexachlorocyclopentadiene

5.0

hexachloroethane

5.0

ideno (1,2,3-c,d) pyrene

10

isophorone

naphthalene

5.0

nitrobenzene

5.0

n-nitrosodimethylamine

5.0

n-nitrosodi-n-propylamine

5.0

n-nitrosodiphenylamine

phenathrene 
PW-1, PW-2, PW-4, PW-5, MW-11, and MW-13. Each organic compound detected is in water samples discussed in the following paragraphs and listed in table 10.

Reporting level is the smallest measured constituent concentration that may be reliably reported using a given analytical method. Detection level is the minimum constituent concentration that can be identified, measured, and reported with confidence that the concentration is larger than zero. The reporting level is set somewhat larger than the detection level because of sample-composition (matrix) effects.

Dissolved-organic-carbon (DOC) concentrations detected in water samples ranged from $1.3 \mathrm{mg} / \mathrm{L}$ in private-supply well $\mathrm{PW}-4$ to $4.3 \mathrm{mg} / \mathrm{L}$ in monitoring well $\mathrm{MW}-8$ (table 10 ). Thurman (1985) reports that typical DOC concentrations in ground water range from 0.2 to $15 \mathrm{mg} / \mathrm{L}$, with a median concentration of $0.7 \mathrm{mg} / \mathrm{L}$. DOC concentrations in surface water usually are larger than in ground water (Thurman, 1985). DOC may be an indicator of organic substances dissolved in water if concentrations are large. Note that it would require a relatively large concentration of organic compounds to affect the DOC concentration because DOC concentration is reported in milligrams per liter, whereas organic compounds are reported in micrograms per liter. There is no discernible pattern of DOC concentrations for the samples collected from the Reno County Landfill area, and all concentrations are in the typical range for DOC concentrations.

The analysis for methylene-blue active substances (MBAS) tests for the presence of surfactants, including alkyl benzene sulfonate and linear alkyl sulfonate (Wershaw and others, 1987). These surfactants are common components of detergents. Organic and inorganic compounds may interfere with the MBAS analysis giving false readings that usually are too large. For small concentrations of MBAS (less than $0.50 \mathrm{mg} / \mathrm{L}$ ), the interference renders the results unreliable (American Public Health Association, 1976).

MBAS concentrations detected in water samples did not equal or exceed $0.50 \mathrm{mg} / \mathrm{L}$. The concentrations ranged from $0.05 \mathrm{mg} / \mathrm{L}$ in monitoring well MW-13 to $0.23 \mathrm{mg} / \mathrm{L}$ in well MW-5 (table 10). Due to the possibility of interference occurring at a concentration of less than $0.50 \mathrm{mg} / \mathrm{L}$, all samples may reflect the interference rather than the true MBAS concentration.

Benzene was detected in water samples from wells MW-5, MW-9, and MW-12, with concentrations ranging from 0.2 to $0.70 \mu \mathrm{g} / \mathrm{L}$ (table 10). Concentrations in water from well MW-9 and the duplicate sample from well MW-9 were larger than the KNL of $0.5 \mu \mathrm{g} / \mathrm{L}$ (table 10 ). Benzene is used as an intermediate in the manufacture of chemical compounds, including pesticides, dyes, detergents, and medicinal chemicals (Sax and Lewis, 1987). It has been used as a solvent for waxes, resins, and oils and has been reported in gasoline at concentrations of less than 5 percent by volume (National Research Council, 1977). Benzene has been listed as a carcinogen by the U.S. Environmental Protection Agency (Budavari and others, 1989).

Bis-(2-ethylhexyl) phthalate was detected in water samples from wells MW-8, MW-9, MW-10, and MW-12. Concentrations did not exceed Kansas drinking-water regulations (table 10). This compound is used as a plasticizer and is ubiquitous; its detection at small concentrations such as this could result from sample processing as well as from actual presence in the ground water.

Chlorobenzene is used as a solvent for paints and in the manufacture of other compounds, including phenol, aniline, and DDT (Sax and Lewis, 1987). Chlorobenzene concentrations were $7.1 \mu \mathrm{g} / \mathrm{L}$ in a water sample from well MW-8 and $0.20 \mu \mathrm{g} / \mathrm{L}$ in a water sample from well MW-9. The concentration in the water sample from well MW-8 exceeded the KNL of $6.0 \mu \mathrm{g} / \mathrm{L}$.

Chloroethane (ethyl chloride) was detected in water samples from wells MW-9 and MW-12 at concentrations of 10 and $6.4 \mu \mathrm{g} / \mathrm{L}$. These concentrations exceed the KNL of $3.7 \mu \mathrm{g} / \mathrm{L}$ (table 10). Chloroethane is used as a refrigerant and a solvent for phosphorus, sulfur, fats, oils, resins, and waxes. It is used also in the 
manufacture of tetraethyl lead and as an insecticide (Sax and Lewis, 1987).

Chloroform was detected in water samples from wells MW-9, MW-14, and PW-3 (table 10). Chloroform is a trihalomethane compound (THM), and the sum of all THMs must be less than $100 \mu \mathrm{g} / \mathrm{L}$ to comply with Federal drinkingwater regulations (U.S. Environmental Protection Agency, 1990b). Chloroform is used as a solvent for fats, oils, rubber, alkaloids, and waxes. It also is used as a fumigant and insecticide. Chloroform is listed as a known carcinogen (Sax and Lewis, 1987).

1,2-dichlorobenzene has many uses including as a solvent for a variety of organic materials and as an oxide for nonferrous metals (Sax and Lewis, 1987). 1,2-dichlorobenzene also is used in dye manufacturing and as an insecticide and fumigant. 1,2-dichlorobenzene was detected in water samples from wells MW-5, MW-8, and MW-9, ranging from 0.20 to $95 \mu \mathrm{g} / \mathrm{L}$. The concentration in the water sample from well MW-8 of $95 \mu \mathrm{g} / \mathrm{L}$ was larger than the $\mathrm{KNL}$ of $62 \mu \mathrm{g} / \mathrm{L}$.

1,3-dichlorobenzene was detected in a water sample from well MW-8 at a concentration of $6.6 \mu \mathrm{g} / \mathrm{L}$; the concentration did not exceed any drinking-water regulations. 1,3-dichlorobenzene is used as fumigant and insecticide (Sax and Lewis, 1987).

1,4-dichlorobenzene commonly is used in households as a moth repellant and as a general fumigant and insecticide. 1,4-dichlorobenzene was detected in water samples from wells MW-5, MW-8, MW-9, and MW-12 (table 10). The concentration in the water sample from well MW- 8 exceeded the KNL of $7.5 \mu \mathrm{g} / \mathrm{L}$.

Dichlorodifluoromethane was detected in water samples from well MW-9 at concentrations of 6.4 and $6.2 \mu \mathrm{g} / \mathrm{L}$ (table 10 ). Concentrations in all water samples were less than any Kansas or Federal drinking-water regulations (table 10). Dichlorodifluoromethane is used as a refrigerant, in the manufacture of plastics, as a low-temperature solvent, and for the freezing of food by direct contact (Sax and Lewis, 1987).

1,1-dichloroethane (ethylidene chloride) was detected in water samples from wells MW-5,
MW-9, and MW-12 (table 10). All samples exceeded the KNL of $0.50 \mu \mathrm{g} / \mathrm{L}$ and $\mathrm{KAL}$ of $5.0 \mu \mathrm{g} / \mathrm{L}$. 1,1-dichloroethane is used as an extraction solvent and as a fumigant (Sax and Lewis, 1987).

1,2-dichloroethane (ethylene dichloride) is considered a carcinogen (U.S. Environmental Protection Agency, 1990e) and has a MCLG of $0 \mu \mathrm{g} / \mathrm{L}$, a MCL of $5.0 \mu \mathrm{g} / \mathrm{L}$, a $\mathrm{KNL}$ of $0.50 \mu \mathrm{g} / \mathrm{L}$, and a $\mathrm{KAL}$ of $5.0 \mu \mathrm{g} / \mathrm{L}$. 1,2-dichloroethane was detected in water samples from well MW-5 at $1.2 \mu \mathrm{g} / \mathrm{L}$, well $\mathrm{MW}-9$ at $4.9 \mu \mathrm{g} / \mathrm{L}$, and well $\mathrm{MW}-12$ at $0.50 \mu \mathrm{g} / \mathrm{L}$. The concentrations in water samples from ells MW-5 and MW-9 exceeded the KNL of $0.50 \mu \mathrm{g} / \mathrm{L}$. 1,2dichloroethane is used extensively in chemical manufacturing, as a lead scavenger in gasoline, in paints and varnishes, as a metal degreaser, in soaps and wetting agents, in ore flotation, as a solvent, and as a fumigant (Sax and Lewis, 1987).

1,1-dichloroethylene (vinylidene chloride) was detected in a water sample from well MW-9 at concentrations of $0.90 \mu \mathrm{g} / \mathrm{L}$, which is larger than the $\mathrm{KNL}$ level of $0.70 \mu \mathrm{g} / \mathrm{L}$. 1,1-dichloroethylene is used to copolymerize with vinyl chloride or acrylonitrile to form various forms of Saran. It also is used as a adhesive and as a component of synthetic fibers (Sax and Lewis, 1987).

1,2-dichloropropane (propylene dichloride) was detected in water samples from well MW-5 at $2.4 \mu \mathrm{g} / \mathrm{L}$ and well $\mathrm{MW}-9$ at 2.0 and $2.1 \mu \mathrm{g} / \mathrm{L}$. Concentrations in water samples from wells MW-5 and MW-9 were larger than the KNL of $0.60 \mu \mathrm{g} / \mathrm{L}$. This compound is used in chemical manufacturing, as a solvent, in scouring compounds, as a metal degreaser, as a nematocide (Sax and Lewis, 1987), and in dry-cleaning fluids.

Diethyl-phthalate concentrations ranged from 0.14 to $1.1 \mu \mathrm{g} / \mathrm{L}$ in water samples from wells MW-8, MW-9, and MW-12. The KNL and KAL were not exceeded in any samples. Diethyl phthalate is used as a solvent for nitrocellulose and cellulose acetate, a plasticizer in solid rocket-fuel propellant, a wetting agent, an insecticide, and in mosquito repellents (Sax and Lewis, 1987). 
Methylene chloride was detected in water samples from wells MW-5, MW-9, and MW-12. KAL and KNL concentrations were not exceeded for this compound. Methylene chloride is used in paint removal, solvent degreasing, plastics processing, blowing agent in foams, solvent extraction, and as an aerosol propellant (Sax and Lewis, 1987).

4-chloro-m-cresol (parachlorometacresol) was detected in the water sample from well MW-8 at a concentration of $2.49 \mu \mathrm{g} / \mathrm{L}$, which does not exceed any drinking-water regulations. 4-chloro-m-cresol is used as an external germicide and as a preservative for glues, gums, paints, inks, textiles, and leather goods (Sax and Lewis, 1987).

Tetrachloroethylene concentrations were $1.3 \mu \mathrm{g} / \mathrm{L}$ in water samples from well MW-5 and 16 and $15 \mu \mathrm{g} / \mathrm{L}$ in water samples from well MW-9. The concentration in the water sample from well MW-5 exceeded the KNL of $0.70 \mu \mathrm{g} / \mathrm{L}$, and concentrations in water samples from well MW-9 exceeded both the KNL and the KAL of $7.0 \mu \mathrm{g} / \mathrm{L}$. Tetrachloroethylene is used as a dry-cleaning solvent, a vapor-degreasing solvent, drying agent for metals, heat-transfer medium, and in the manufacture of fluorocarbons (Sax and Lewis, 1987).

Toluene was detected in water samples from well MW-9 at concentrations of $0.2 \mu \mathrm{g} / \mathrm{L}$. This concentration did not exceed any drinkingwater regulations. Toluene has a variety of uses, including use in aviation gasoline, solvent for paints, adhesive solvent for toys and model airplanes, and explosives (TNT) (Sax and Lewis, 1987).

1,2-trans-dichloroethylene (acetylene dichloride) was detected in water samples from wells MW-5, MW-9, and MW-12. Concentrations in water samples from wells MW-5 and MW-9 exceeded the $\mathrm{KNL}$ of $7.0 \mu \mathrm{g} / \mathrm{L}$. 1,2-transdichloroethylene is used as a solvent for organic materials, dye extraction, perfumes, lacquers, and thermoplastics (Sax and Lewis, 1987). 1,2 trans-dichloroethylene is an intermediate degradation product of trichloroethylene (U.S. Environmental Protection Agency, 1987).

1,1,1-trichloroethane was detected in a water sample from well MW-9 at concentrations of $0.5 \mu \mathrm{g} / \mathrm{L}$, which did not exceed any State or
Federal drinking-water regulations. 1,1,1trichloroethane is used for precision-instrument cleaning, metal degreasing, as a pesticide, and in textile processing (Budavari and others, 1989).

Trichloroethylene concentrations ranged from 0.5 to $24 \mu \mathrm{g} / \mathrm{L}$ in water samples from wells MW-5, MW-9, and MW-12. The concentrations in samples from wells MW-5 and MW-9 exceeded the State $\mathrm{KNL}(0.5 \mu \mathrm{g} / \mathrm{L})$ and $\mathrm{KAL}$ $(5.0 \mu \mathrm{g} / \mathrm{L})$ and the Federal MCL $(5.0 \mu \mathrm{g} / \mathrm{L})$. The MCLG for this compound is $0 \mu \mathrm{g} / \mathrm{L}$. Sax and Lewis (1987) cite the use of trichloroethylene in metal degreasing, as a extraction solvent for oils, fats, and waxes, in dry cleaning, as a refrigerant and heat-exchange liquid, a fumigant, in cleaning and drying electronic parts, as a dilutent in paints and adhesives, in textile processing, and in aerospace operations. Trichloroethylene can be biologically degradated to 1,2-dichloroethylene and vinyl chloride under aerobic conditions (Rowland and Eisenberg, 1989).

Vinyl chloride is a known carcinogen and is used in polyvinyl chloride and copolymers, in organic synthesis, and as a adhesive for plastic (Sax and Lewis, 1987). Vinyl chloride was detected in water samples from wells MW-5, MW-9, and MW-12, and concentrations ranged from 12 to $24 \mu \mathrm{g} / \mathrm{L}$. These concentrations exceed the $\mathrm{KNL}(0.20 \mu \mathrm{g} / \mathrm{L}), \mathrm{KAL}(2.0 \mu \mathrm{g} / \mathrm{L})$, and MCL $(2.0 \mu \mathrm{g} / \mathrm{L})$. The MCLG for vinyl chloride is $0 \mu \mathrm{g} / \mathrm{L}$. Vinyl chloride is a degradation end product of trichloroethylene (Rowland and Eisenberg, 1989). Vinyl chloride is not known to occur in nature. The use of vinyl chloride as a propellent in aerosols was banned in 1974 (National Research Council, 1977).

Xylene was detected in water samples from wells MW-8 and MW-9. Concentrations were less than all drinking-water regulations. Xylene is used as aviation gasoline, in protective coatings, as a solvent for alkyd resins, lacquers, enamels, and rubber cements, and in the synthesis of organic chemicals (Sax and Lewis, 1987).

Several of the organic compounds tentatively identified in water samples (table 11) are grouped into five general category headings in table 13 . These category headings 
Table 13. Common uses of some organic compounds tentatively identified in water samples collected from the Reno County Landfill and vicinity

\section{Solvents}

2-Butoxyethanol

Chlorofluoromethane

Dichlorofluoromethane

Diethyl ether

1,3-Dimethyl benzene

2,4-Dimethyl phenol

2-(2-ethoxyethoxy)-

ethanol (Carbitol)

Methylbenzene

N-(1,1-Dimethylethyl)-3-

methylbenzamide (Deet)

Tetrachloroethene

\section{Dyes}

2-Cyanocarbozole \& RBr2

1,3-Dimethyl benzene

2,4-Dimethyl phenol

$\mathrm{N}$-(4-Hydroxyphenyl)-acetamide

\section{Organic Chemical Synthesis}

\author{
Benzene, (phenoxymethyl) \\ Benzothiazole \\ Diethyl ether \\ Hexadecanoic acid \\ 2-Methyl-benzenesulfonamide \\ $\mathrm{N}$-ethyl toluene sulfonamide \\ Tricosane
}

\section{Degreasers, Soaps, and Detergents}

Dodecanoic acid

Phosphoric acid

Octadecanoic acid

\section{Pesticides}

\author{
1,3-Dimethyl benzene \\ 1,4-Dimethyl benzene \\ 2,4-Dimethyl phenol \\ Dodecanoic acid \\ 2-Methyl-azetidine \\ N-(1,1-Dimethylethyl)-3- \\ methylbenzamide (Deet)
}

do not represent a complete list of the uses for these organic compounds. When listed under a heading, a compound may be used in the production process associated with the category heading, such as in the manufacture of solvent, or it also could be used as one of the category headings, such as solvent. Other explanations exist for the occurrence of these tentatively identified compounds, which include the degradation of or chemical reactions from other compounds creating new derivative compounds. Unknown organic compounds also were identified in all samples.

\section{EFFECTS OF LANDFILL ON WATER QUALITY}

In general, landfill leachate may have large concentrations of sodium, potassium, sulfate, chloride, iron, manganese, and other ions and trace elements (table 9) as well as organic compounds (table 10). As a result of large ion concentrations, dissolved-solids concentrations also are large. Landfill leachate may percolate downward and mix with ground water such that large concentrations of ions, trace elements, and organic compounds in leachate may be diluted. Despite possible dilution, concentrations of major ions, trace elements, and organic compounds in ground water downgradient of landfills commonly are larger than upgradient. The best indicators of leachate in ground water are increased concentrations of chloride, ammonia, potassium (Francis and Auerbach, 1983), iron, manganese, and organic compounds (Myers and Bigsby, 1989, 1990).

Two water types--a sodium bicarbonate and a sodium chloride type water--were present in the vicinity of the Reno County Landfill, (fig. 12). The distribution of water types may be related to the source of water within the 
different Quaternary deposits or from the proximity to the Arkansas River and Salt Creek. The Arkansas River and Salt Creek contain large concentrations of chloride, which may seep downward and disperse into the ground water causing a sodium chloride type water to dominate (fig. 12). Recharge to ground water from these streams is indicated by the water-sample analyses from wells MW-8, MW-11, and MW-12 (fig. 12).

The Reno County Landfill does not have a discernible effect on physical properties of water or on concentrations of inorganic constituents at downgradient locations, with two possible exceptions. Iron and manganese concentrations within the landfill property (wells MW-5 and MW-8) are larger than concentrations in upgradient ground water. This would indicate that some iron and manganese concentrations are derived from the landfill. The present (1991) extent of movement of these constituents downgradient from the landfill is not specifically known but is estimated to be limited to a small area (fig. 13). Iron and manganese concentrations did not substantially exceed upgradient concentrations (well MW-10) in water samples from wells MW-9, MW-11, MW-12, MW-14, PW-2, and PW-3, so any water with large concentrations occurs in the central (well MW-5) and northeast (well MW-8) parts of the landfill (fig. 13). Increased concentrations may be due to the dissolution of oxide coatings on sand grains facilitated by probable reducing conditions under parts of the landfill. Wells MW-11 and MW-14 and sampling site CR-1 had concentrations of manganese that also exceeded the Kansas and Federal SMCL but not to the extent of wells MW-5 or MW-8 (table 9). Specific-conductance values and dissolvedsolids concentrations increased as proximity to Salt Creek increased (figs. 14 and 15).

The presence of organic compounds in the ground-water samples collected from wells within the landfill property (wells MW-5, MW-8, MW-9, MW-12) indicate that the landfill's leachate is affecting the ground-water quality. The leachate from the landfill is mixing with ground water, which results in dilution of the leachate with respect to certain organic compounds. The largest concentrations of many organic compounds occurred in water from well MW-9. Figures 16-19 show the possible extent of plumes for 1,1-dichloroethane, trichloroethylene, vinyl chloride, and 1,2-transdichloroethylene. Vinyl-chloride concentrations detected in wells MW-5 and MW-9 were similar if the two sample concentrations from well MW-9 are averaged (MW-9 and MW-9dup).

There are several possible explanations as to why the water samples from well MW-9 contain the largest concentrations of volatile organic compounds (VOC's). The first and most likely is that leachate from both the old city section and the old county section of the landfill is contributing to the degradation of the quality of ground water. Concentrations of trichloroethylene and its degradation products 1,2-trans-dichloroethylene and vinyl chloride are largest in water samples from well MW-9. These large concentrations indicate that the probable source of these contaminants are from the old county section and that the leachate plume is moving downgradient along the ground-water flow path. Trichloroethylene and 1,2-trans-dichloroethylene have densities greater than 1.2 grams per milliliter and probably have moved vertically downward more than horizontally (figs. 17 and 19). However, vinyl chloride has a density of less than 1.0 gram per milliter, will rise to the water table, and has probably moved farther horizontally than vertically (fig. 18). A possible alternative explanation is that contamination of the ground water is not occurring as a steady, continuous injection of leachate but rather in pulses during periods of increased precipitation and rapid infiltration. If this explanation is used, figures $16,17,18$, and 19 show a pulse of contaminated water passing well MW-9 during the sampling in August. The concentrations in water samples from well MW-5 then would indicate the tail end of this pulse. A third explanation is that some combination of these two mechanisms may be occurring.

The lateral extent of VOC contamination is not precisely known but is suspected to extend to the east of the landfill approximately 1.5 miles. This distance is estimated from the sampling in 1990 and from previous sampling (Wilson Laboratories, written commun., 1989, 1990) when organic compounds were detected in water samples from private-supply wells PW-6 and PW-7. If organic compounds were placed in the old city section of the landfill in 1967 and the 
average ground-water velocity is 0.75 foot per day, then leachate may have been transported 1.2 miles by 1990 . During this investigation, VOC's were not detected in water samples from wells PW-2, PW-5, and MW-11, and only small concentrations were detected in wells PW-3 and MW-14. These five wells can be used to outline an outer limit where concentrations of VOC's were less than detection levels. VOC's may extend vertically towards the top of the confining bedrock as indicated by the concentrations in well MW-12 (figs. 16, 17, 18, and 19). The contaminants are dispersed and diluted by concentration gradients, by density differences of organic compounds, and by ground-water movement.

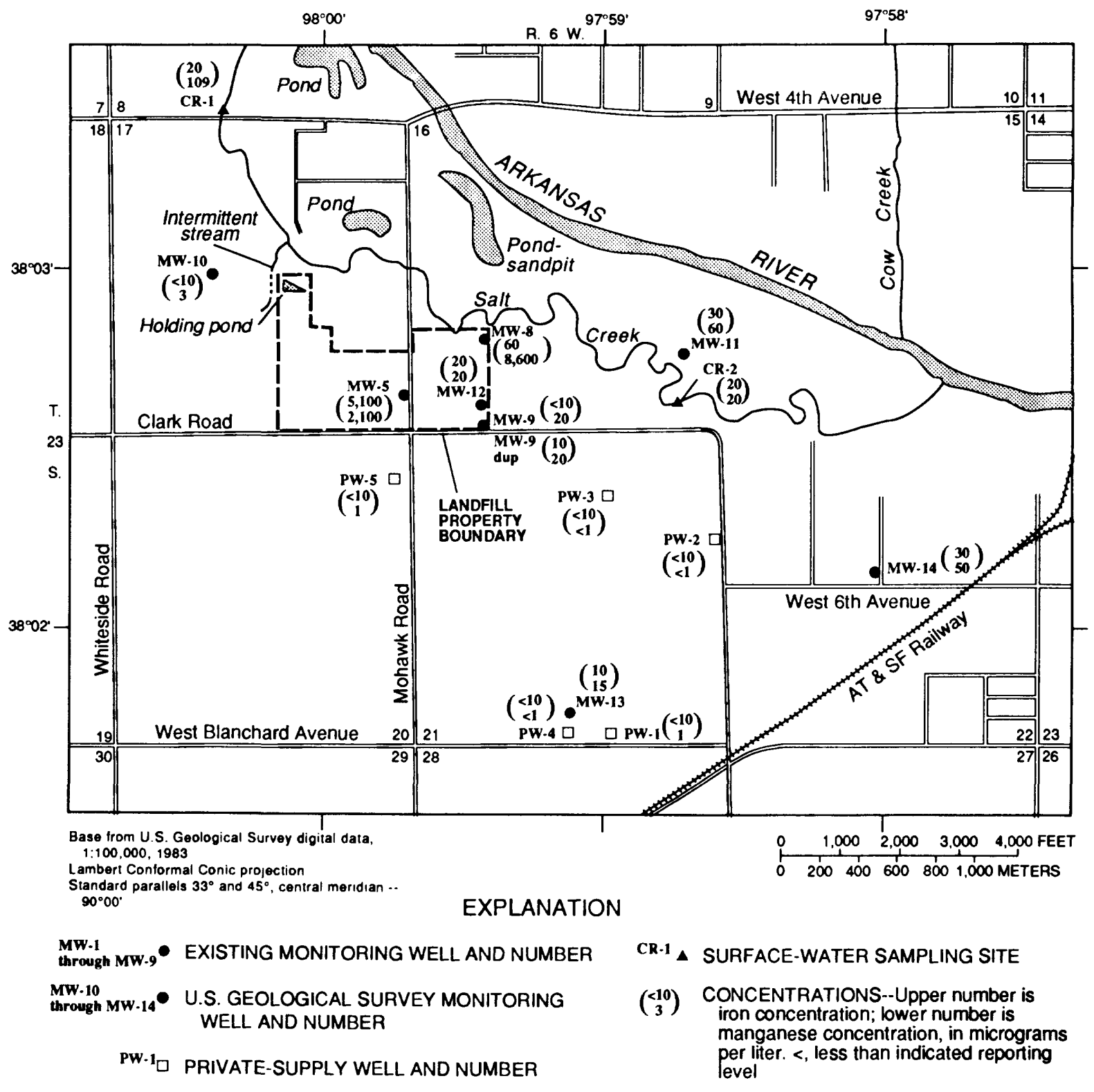

Figure 13. Distribution of iron and manganese concentrations in water samples, Reno County Landfill and vicinity, August 7-8, 1990. 


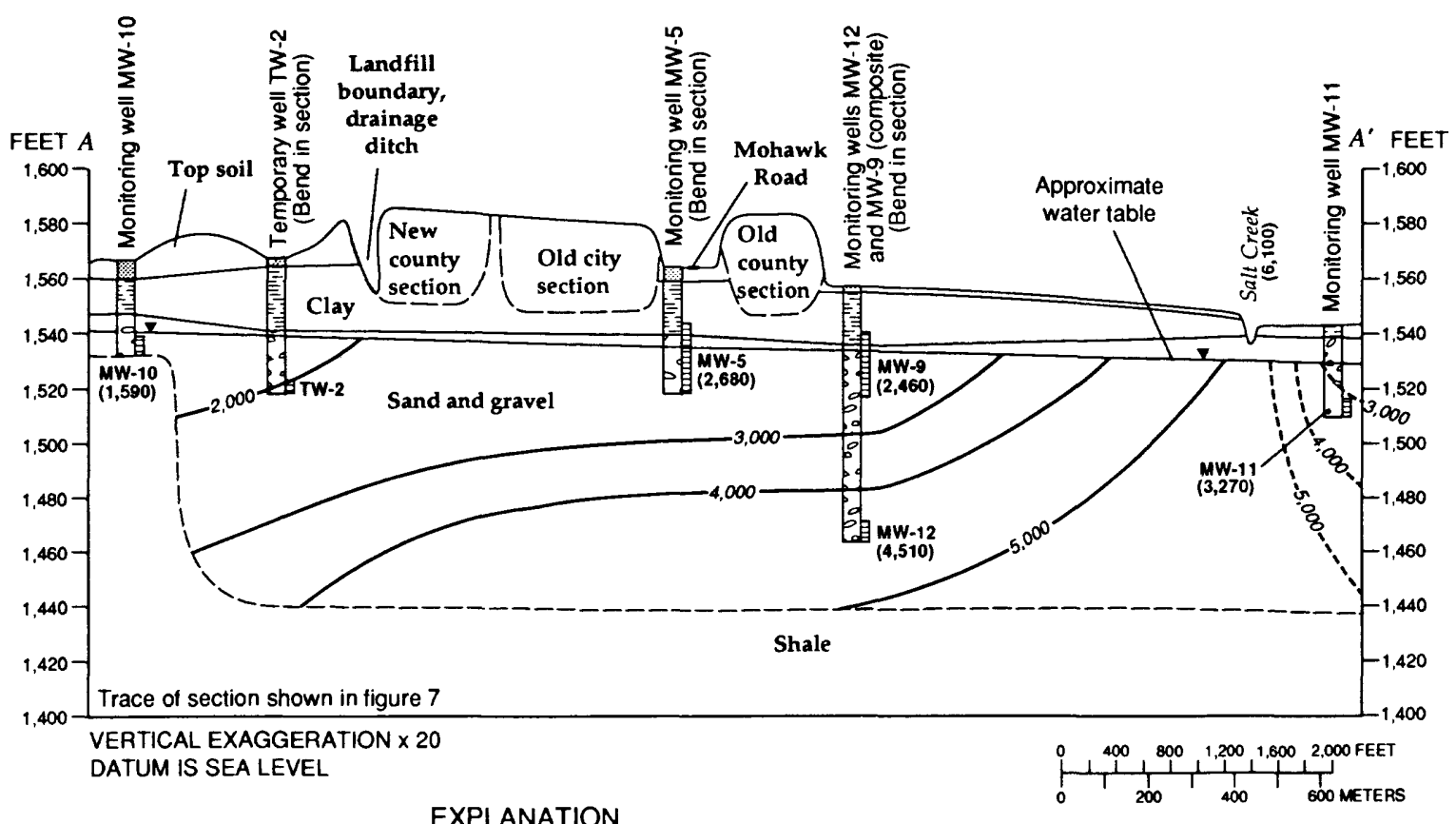

EXPLANATION
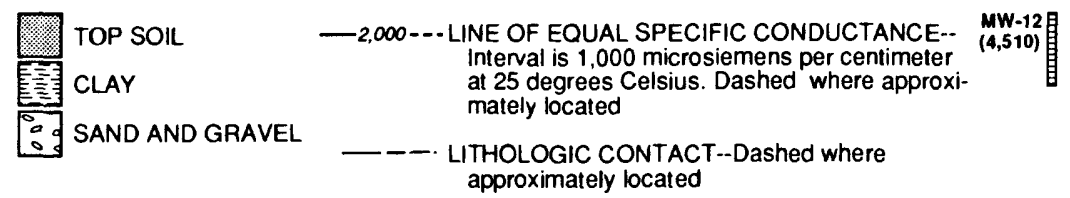

WELL-SCREEN-INTERVAL AND NUMBER--Number in parentheses is specific conductance, in microsiemens per centimeter at 25 degrees Celsius

Figure 14. Distribution of field-determined specific-conductance values, Reno County Landfill and vicinity, August 7-8, 1990.

\section{SUMMARY AND CONCLUSIONS}

An investigation of the hydrogeology and ground-water quality in the vicinity of the Reno County Landfill near Hutchinson, Kansas, was conducted during August 1990 to March 1991.

The geology of Reno County consist of rocks of Permian age underlying most of the county, overlain by unconsolidated deposits of sand and gravel of Quaternary age. Ground-water flow in the Quaternary sediment generally is to the east-southeast. The geology in the vicinity of the landfill consists of the Permian Ninnescah Shale overlain by Quaternary sand-and-gravel deposits, a clay or silty clay layer, and top soil. The sand-and-gravel deposits generally are between 100 to 140 feet thick. However, in some well borings, shale was encountered at 35 feet below land surface. The thickness of the clay or silty clay layer generally varies increasing to about 50 feet south of the landfill. Salt Creek is located directly north of the landfill and was determined to be a losing stream during the investigation. The ground-water flow in the sand-and-gravel layer is from west to east beneath the landfill parallel to Salt Creek. The average linear velocity of the ground water was calculated to be 0.75 foot per day, with a hydraulic conductivity of 145 feet per day.

The Quaternary sediment yields the largest quantities of water to wells in Reno County. The water has large concentrations of chloride, and the surface water in Reno County generally is unsuitable for most uses because of large concentrations of chloride.

Two water types were found in the study area--sodium bicarbonate type water and a sodium chloride type. Chemical analysis of water samples from the monitoring wells, private-supply wells, and creek samples indicate large concentrations of chloride and other major ions. These large chloride concentrations affect the specific conductance and dissolved-solids concentrations, which increase with increased proximity to Salt Creek 

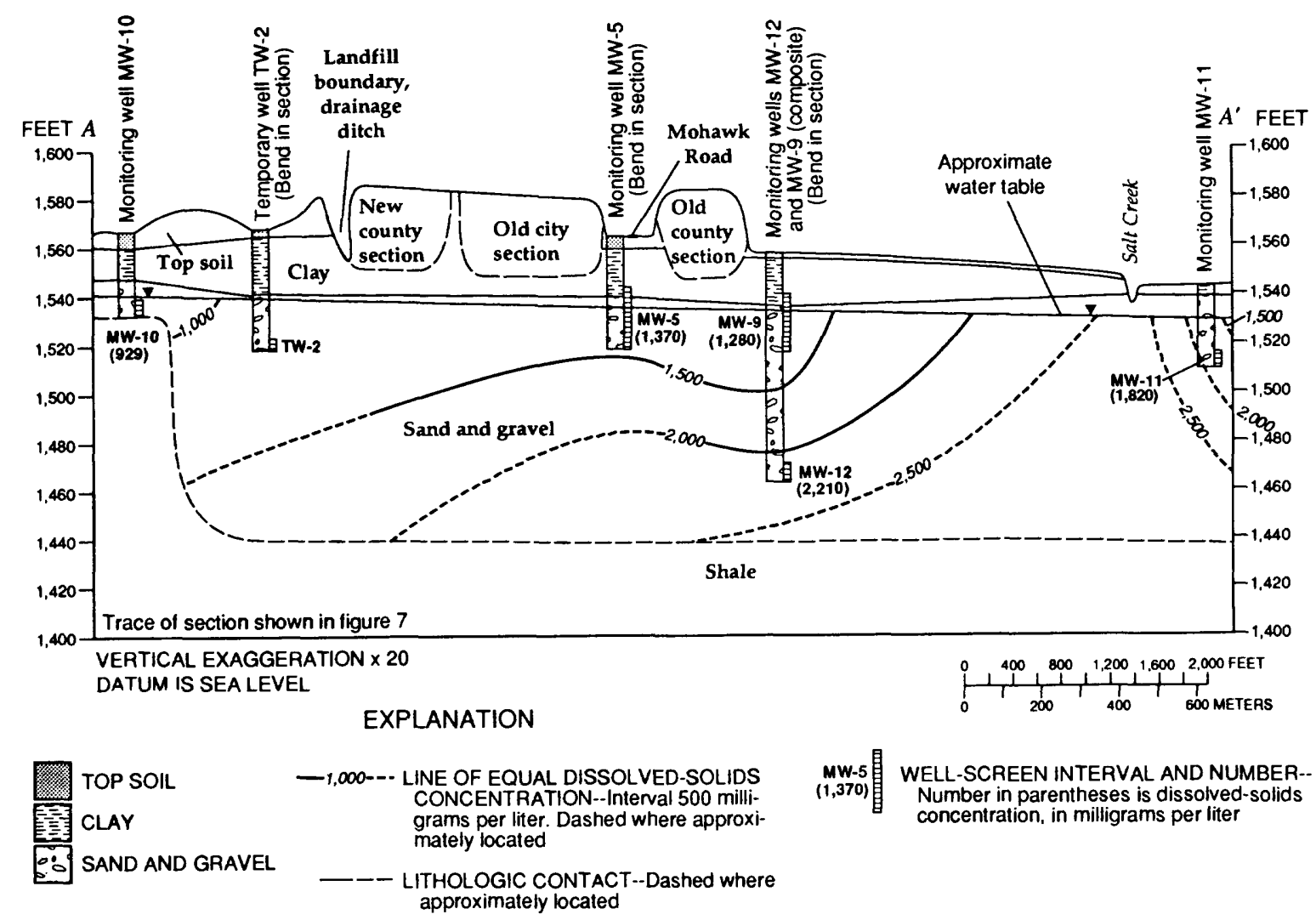

Figure 15. Distribution of concentrations of dissolved solids at 105 degrees Celsius, Reno County Landfill and vicinity, August 7-8, 1990.

and the Arkansas River. The sodium chloride water type occurs in proximity to Salt Creek and the Arkansas River, indicating that major-ion concentrations may be derived from surface-water recharge to the ground water.

The other inorganic constituents that have larger concentrations in ground water within the landfill property than in upgradient wells are iron and manganese. Large concentrations of these constituents occur in water samples from wells MW-5 and MW-8 located on the landfill and probably are derived from both the old city and the old county sections. Iron and manganese movement probably is limited to a small area on and east of the landfill. However, water samples from Salt Creek and water samples from wells near Salt Creek and downgradient of the landfill have similar iron and manganese concentrations. The similarity of iron and manganese concentrations and ground-water-flow direction indicate Salt Creek is the probable source for these constituents downgradient of the landfill.
Analysis of water samples collected in August 1990 indicate that 23 volatile organic compounds were present in the water from monitoring wells. Of these 23, 1,1dichloroethane, tetrachloroethylene, trichloroethylene, and vinyl chloride were detected at concentrations larger than Kansas and Federal drinking-water regulations. The organic compounds that exceeded these regulations were detected in water beneath the landfill.

The downgradient extent of the leachate and rate of leachate migration are not specifically known, but the leachate plume is estimated to proceed directly east from the landfill about 1.5 miles along the ground-water flow paths. Volatile organic compounds were not detected in downgradient wells MW-11, PW-3, and PW-5, and only small concentrations were detected in downgradient wells PW-2 and MW-14. These downgradient wells can be used to outline a nondetectable limit or boundary for organic-compound migration. These organic compounds probably are derived from both the 

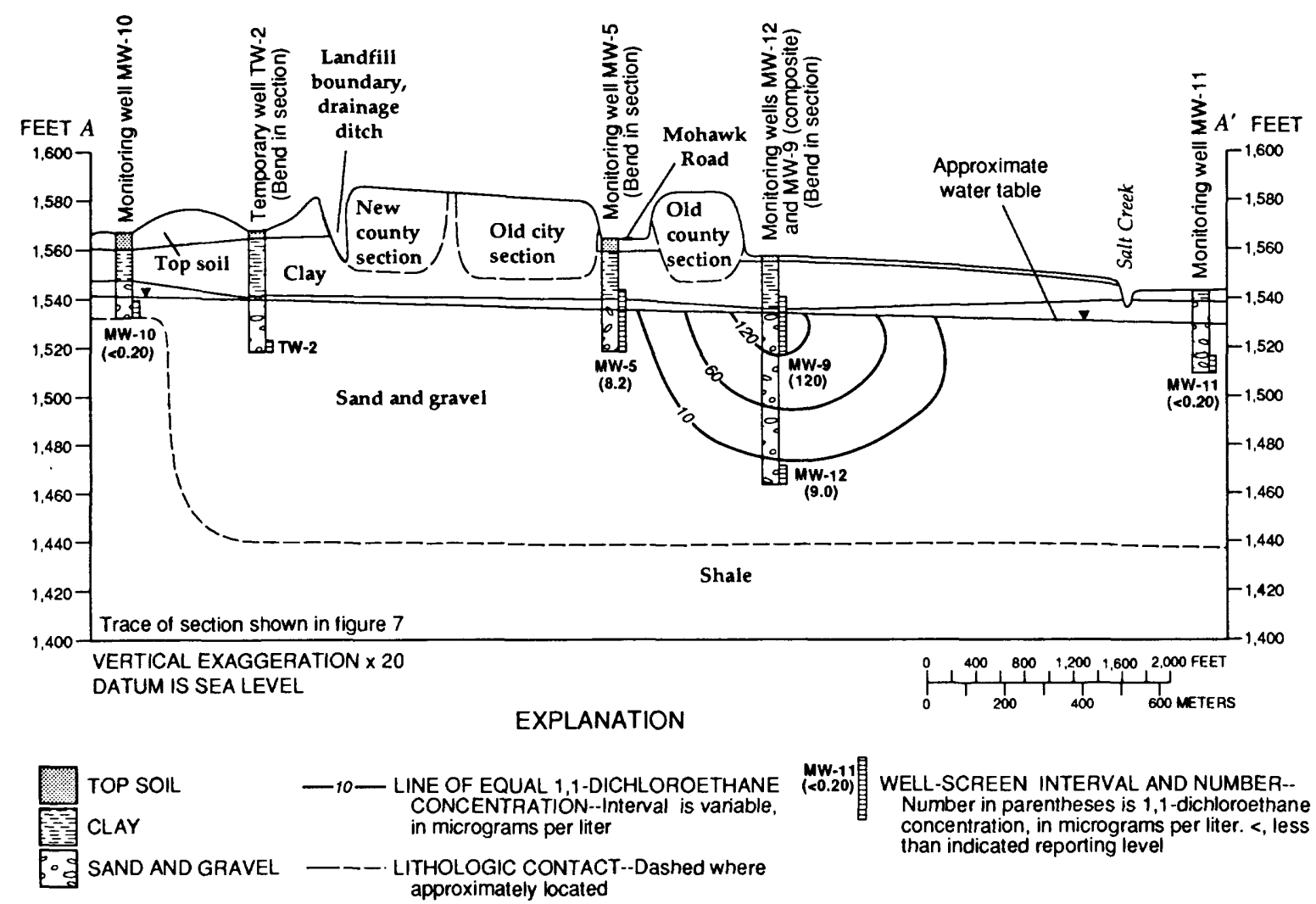

Figure 16. Distribution of concentrations of 1,1-dichloroethane, indicating general location of leachate plume, Reno County Landfill and vicinity, August 7-8, 1990.

old city and old county sections of the landfill. The concentrations of organic compounds detected in ground water decreased in the direction of ground-water flow, probably as a result of concentration gradients, density differences of the organic compounds, and dilution by ground-water movement.

Further monitoring, consisting of quarterly sampling, would provide improved knowledge of seasonal variations of chemical constituents, water levels, and direction of ground-water movement. After quarterly sampling, annual sampling would provide improved knowledge of the long-term effects of the landfill on the shallow aquifer.

\section{REFERENCES CITED}

American Public Health Association, 1976, Standard methods for the examination of water and wastewater (14th ed.): Washington D.C., American Public Health Association, American Public Water Works
Association, Water Pollution Control Federation, $1193 \mathrm{p}$.

Apgar, M.A., and Langmuir, Donald, 1971, Groundwater pollution potential of a landfill above the water table: Ground Water, v. 9, no. 6, p. 76-93.

Baedecker, M.J., and Back, William, 1979, Hydrogeological processes and chemical reactions at a landfill: Ground Water, v. 17, no. 5 , p. 429-437.

Bayne, C.K, 1956, Geology and ground-water resources of Reno County, Kansas: Kansas Geological Survey Bulletin 120, 130 p.

Bouwer, Herman, and Rice, R.C., 1976, A slug test for determining hydraulic conductivity of unconfined aquifers with completely or partially penetrating wells: Water Resources Research, v. 12 , no. 3 , p. 423-428. 


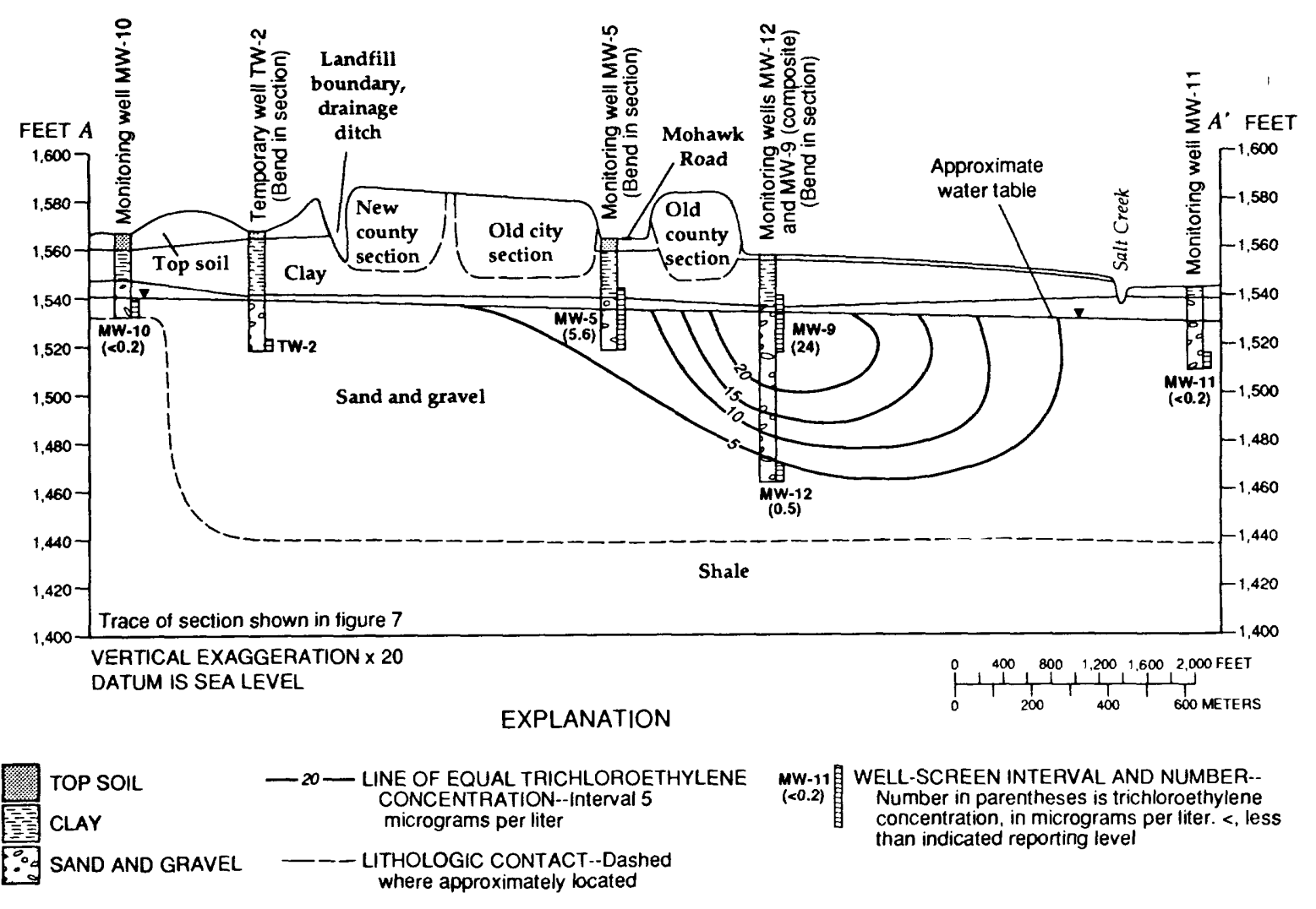

Figure 17. Distribution of concentrations of trichloroethylene, indicating general location of leachate plume, Reno County Landfill and vicinity, August 7-8, 1990.

Budavari, Susan, O'Neil, M.J., Smith, Ann, and Heckelman, P.E., eds., 1989, The Merck index--An encyclopedia of chemicals, drugs, and biologicals (11th ed.): Rahway, New Jersey, Merck and Co., Inc., 1606 p.

Christensen, T.H., Cossu, Raffaello, and Stegmann, Rainer, 1989, Sanitary landfilling--Process, technology and environmental impact: New York, Harcourt Brace Jovanovich Publ., p. 29-51.

Fetter, C.W., 1988, Applied hydrogeology: Columbus, Ohio, Merrill Publishing Co., $592 \mathrm{p}$.

Fishman, M.J., and Friedman, L.C., eds., 1989, Methods for determination of inorganic substances in water and fluvial sediments: U.S. Geological Survey Techniques of Water-Resources Investigations, Book 5, Chapter A1, 545 p.

Francis, C.W., and Auerbach, S.I., 1983,
Environment and solid waste-Characterization, treatment, and disposal: Boston, Butterworth Publ., p. 315-321.

Freeze, R.A., and Cherry, J.A., 1979, Groundwater: Englewood Cliffs, New Jersey, Prentice-Hall, Inc., 604 p.

Gogel, Tony, 1981, Discharge of saltwater from Permian rocks to major stream-aquifer systems in central Kansas: Kansas Geological Survey, Chemical Quality Series $9,60 \mathrm{p}$.

Hathaway, L.R., Waugh, T.C., Galle, O.K, and Dickey, H.P., 1981, Chemical quality of irrigation water in the Equus beds area, south-central Kansas: Kansas Geological Survey, Chemical Quality Series 10, 45 p.

Heath, R.C., 1982, Basic ground-water hydrology: U.S. Geological Survey WaterSupply Paper 2220, 84 p. 

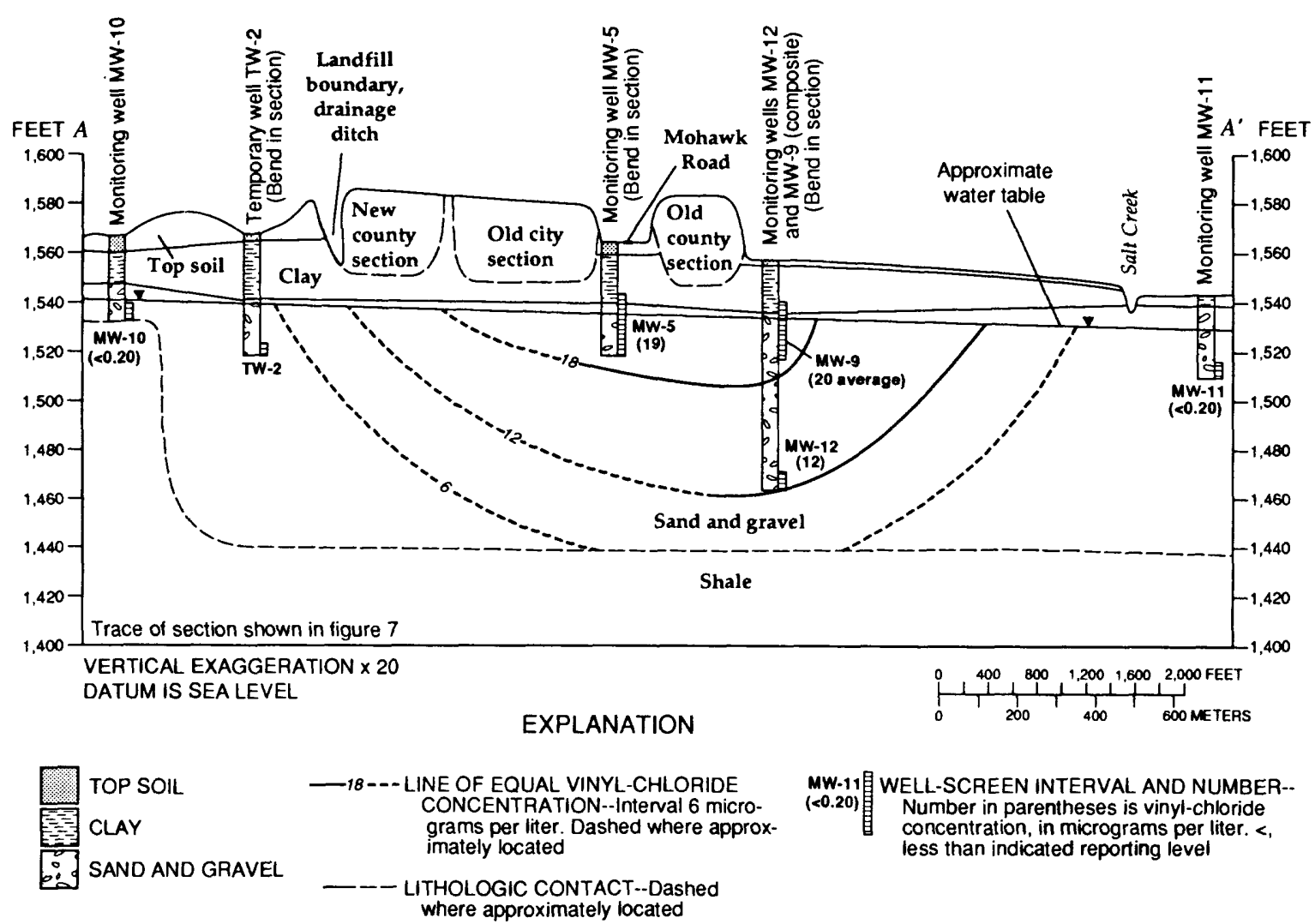

MW-11目 WELL-SCREEN INTERVAL AND NUMBER--

$(<0.20)$ 貝 Number in parentheses is vinyl-chloride concentration, in micrograms per liter. <, less than indicated reporting level

Figure 18. Distribution of concentrations of vinyl chloride (density $=0.91$ ), indicating general location of leachate plume, Reno County Landfill and vicinity, August 7-8, 1990.

Hem, J.D., 1985, Study and interpretation of the chemical characteristics of natural water (3d ed.): U.S. Geological Survey Water-Supply Paper 2254, 263 p.

Hvorslev, M.J., 1951, Time lag and soil permeability in ground water observations: U.S. Army Corps of Engineers Waterways Experimentation Station, Bulletin 73, 50 p.

Institute for Public Policy and Business Research, 1991, Kansas statistical abstract, 1989-90: Lawrence, University of Kansas, $320 \mathrm{p}$.

Kansas Department of Health and Environment, 1986, Explanation of your drinking water analysis: Topeka, Kansas, October 28, 1986, pamphlet.

Kemblowski, M.W., and Klein, C.L., 1987, An automated numerical evaluation of slug test data: Groundwater, 1988 , v. 26 , no. 4 , p. 435-438.
Leonard, R.B., and Kleinschmidt, M.K., 1976, Saline water in the Little Arkansas River basin, south-central Kansas: Kansas Geological Survey, Chemical Quality Series 3 , p. 1-10.

Myers, N.C., and Bigsby, P.R., 1989, Hydrogeology and ground-water-quality conditions at the Geary County Landfill, northeast Kansas, 1988: U.S. Geological Survey Water-Resources Investigations Report 89-4114, 41 p.

1990, Hydrogeology and ground-waterquality conditions at the Emporia-Lyon County Landfill, eastern Kansas, 1988: U.S. Geological Survey Water-Resources Investigations Report 90-4043, 42 p.

National Oceanic and Atmospheric Administration, 1967-90, Climatological data, annual summary, Kansas: Asheville, North Carolina (published monthly). 


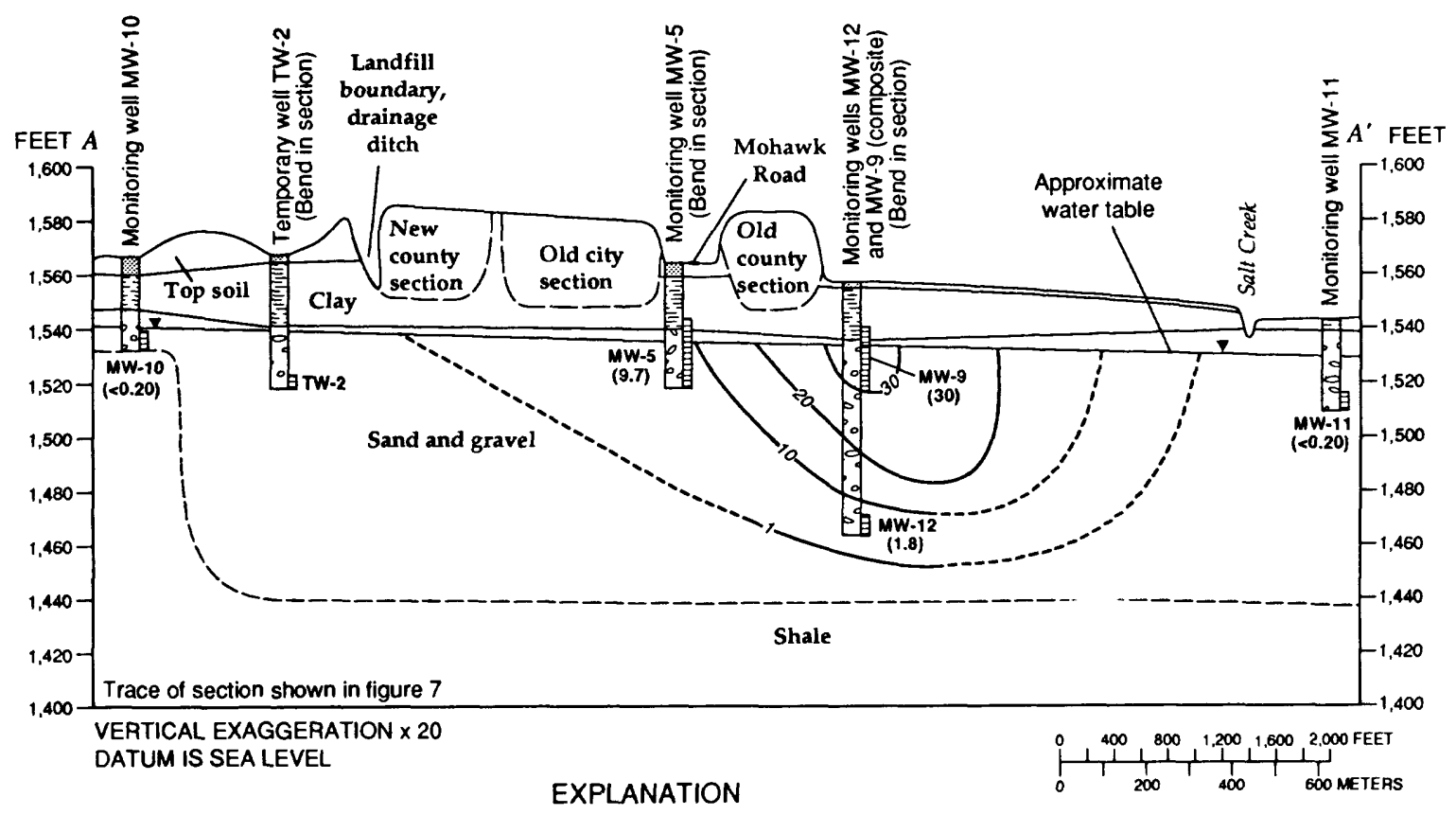

TOP SOIL
CLAY
O- SAND AND GRAVEL
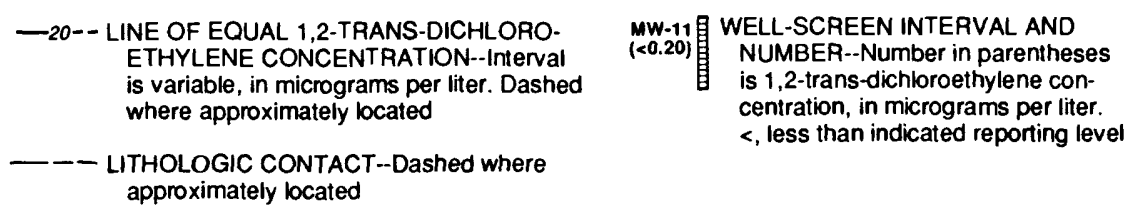

approximately located

Figure 19. Distribution of concentrations of 1,2-trans-dichloroethylene (density $=1.21$ ), indicating general location of leachate plume, Reno County Landfill and vicinity, August 7-8, 1990.

National Research Council, 1977, Drinking water and health: Washington, D.C., National Academy of Sciences, $939 \mathrm{p}$.

Olson, G.W., 1974, Using soils of Kansas for waste disposal: Kansas Geological Survey Bulletin 208, $51 \mathrm{p}$.

Reed, T.B., and Burnett, R.D., 1985, Compilation and analyses of aquifer performance tests in eastern Kansas: U.S. Geological Survey Open-File Report 85-200, p. 103-105.

Rockers, J.J., Ratcliff, Ivan, Dowd, L.W., and Bouse, E.F., 1966, Soil survey of Reno County, Kansas: Soil Conservation Service, Series 1960, no. 29, 72 p.

Rowland, M.A., and Eisenberg, T.N., 1989, Anaerobic biodegradation of trichloroethylene in a shallow aquifer, in the Proceedings of the Third Outdoor Action Conference on Aquifer Restoration, Ground Water Monitoring and Geophysical Methods,
Orlando, Florida, May 22-25, 1989: National Water Well Association, p. 551-564.

Sax, N.I., and Lewis, Richard, Sr., 1987, Hawley's condensed chemical dictionary (11th ed.): New York, Van Nostrand Reinhold Co., $1288 \mathrm{p}$.

Schoewe, W.H., 1949, The geography of Kansas, part II.--Physical geography: Transactions of the Kansas Academy of Science, v. 52, no. 3, p. 261-333.

Snyder, J.D., and Dellwig, L.F., 1961, Plastic flowage of salt in mines at Hutchinson and Lyons, Kansas: Kansas Geological Survey Bulletin 152, part 2, $32 \mathrm{p}$.

Steiner, R.C., Fungaroli A.A., Schoenberger R.J., and Purdom P.W., 1971, Criteria for sanitary landfill development: Public Works, v. 102, no. 3 , p. 77-79. 
Stiff, H.A., Jr., 1951, The interpretation of chemical water analyses by means of patterns: Journal of Petroleum Technology, v. 3 , no. 10 , p. $15-17$.

Tchobanoglous, George, Theisen, Hilary, and Eliassen, Rolf, 1977, Solid wastes-Engineering principles and management issues: New York, McGraw-Hill, 621 p.

Thurman, E.M., 1985, Organic geochemistry of natural water: Boston, Martinus Nijihoff/Dr. W. Junk Publ., 497 p.

U.S. Department of Agriculture, 1957, Soil--The 1957 yearbook of agriculture: Washington, D.C., p. 751-770.

U.S. Environmental Protection Agency, 1973, An environmental assessment of potential gas and leachate problems at land disposal sites: U.S. Environmental Protection Publication SW-100.of., $33 \mathrm{p}$.

1975, Gas and leachate from land disposal of municipal solid waste--Summary report: Cincinnati, Ohio, U.S. Environmental Protection Agency, Municipal Environment Research Laboratory, 1975.

1987, National primary drinking-water regulations--Synthetic organic chemicals (40 CFR Parts 141 and 142): Federal Register, v. 52 , no. 130 , July 8,1987 , p. 25690-25702.

1990a, Maximum contaminant level goals (subpart F of part 141, National primary drinking-water regulations): U.S. Code of Federal Regulations, Title 40, Parts 100 to 149 , revised as of July 1, 1990, p. 620 .

1990b, Maximum contaminant levels (subpart B of part 141, National primary drinking-water regulations): U.S. Code of Federal Regulations, Title 40, Parts 100 to
149 , revised as of July 1,1990 , p. 559 .

1990c, National revised primary drinking-water regulations: Maximum contaminant levels (subpart G of part 141, National primary drinking-water regulations): U.S. Code of Federal Regulations, Title 40, Parts 100 to 149, revised as of July 1,1990, p. 621 .

1990d, National secondary drinking-water regulations (part 143, National secondary drinking-water regulations): U.S. Code of Federal Regulations, Title 40, Parts 100 to 149 , revised as of July 1, 1990, p. 674 .

1990e, Maximum contaminant levels (subpart D of part 141, National primary drinking-water regulations): U.S. Code of Federal Regulations, Title 40, Parts 100 to 149 , revised as of July 1, 1990, p. 559.

Wershaw, R.L., Fishman, M.J., Grabbe, R.R., and Lowe, L.E., eds., 1987, Methods for the determination of organic substances in water and fluvial sediments: U.S. Geological Survey Techniques of Water-Resources Investigations, Book 5, Chapter A3, 80 p.

Williams, C.C., 1946, Ground-water conditions in Arkansas River valley in the vicinity of Hutchinson, Kansas: Kansas Geological Survey Bulletin 64, p. 145-216.

Williams, C.C., and Lohman, S.W., 1949, Geology and ground-water resources of a part of south-central Kansas, with specific references to the Wichita municipal water supply: Kansas Geological Survey Bulletin $79,455 \mathrm{p}$. 